\title{
The Development of an Agricultural Landscape Along a Portion of the U.S. Highway 277 Corridor, with a Case Study of the Cotton Industry in Haskell, Texas
}

Martha Doty Freeman

Follow this and additional works at: https://scholarworks.sfasu.edu/ita

Part of the American Material Culture Commons, Archaeological Anthropology Commons, Environmental Studies Commons, Other American Studies Commons, Other Arts and Humanities Commons, Other History of Art, Architecture, and Archaeology Commons, and the United States History Commons

Tell us how this article helped you.

This Article is brought to you for free and open access by the Center for Regional Heritage Research at SFA ScholarWorks. It has been accepted for inclusion in Index of Texas Archaeology: Open Access Gray Literature from the Lone Star State by an authorized editor of SFA ScholarWorks. For more information, please contact cdsscholarworks@sfasu.edu. 


\section{The Development of an Agricultural Landscape Along a Portion of the U.S. Highway 277 Corridor, with a Case Study of the Cotton Industry in Haskell, Texas}

\section{Licensing Statement}

This is a work produced for the Texas Department of Transportation (TxDOT) by the report producer. TxDOT and the report producer jointly own all rights, title, and interest in and to all intellectual property developed under TXDOT's contract with the report producer. The report may be cited and brief passages from this publication may be reproduced without permission provided that credit is given to both TXDOT and the report producer. Permission to reprint an entire chapter, section, figures or tables must be obtained in advance from either the Supervisor of the Archeological Studies Branch, Environmental Affairs Division, Texas Department of Transportation, 125 East 11th Street, Austin, Texas, 78701 or from the report producer. 


\section{THE DEVELOPMENT OF AN AGRICULTURAL LANDSCAPE ALONG A PORTION OF THE U.S. HIGHWAY 277 CORRIDOR, WITH A CASE STUDY OF THE COTTON INDUSTRY IN HASKELL, TEXAS}

by

Martha Doty Freeman

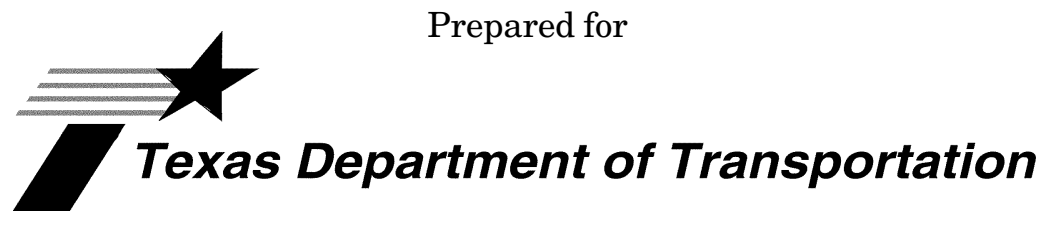

Environmental Affairs Division

HISTORICAL STUDIES REPORT NO. 2003-02

Prepared by

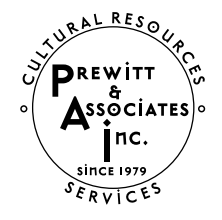

Prewitt and Associates, Inc.

Cultural Resources Services

Austin, Texas

REPORTS OF INVESTIGATIONS, NUMBER 138

May 2003 


\title{
THE DEVELOPMENT OF AN AGRICULTURAL LANDSCAPE ALONG A PORTION OF THE U.S. HIGHWAY 277 CORRIDOR, WITH A CASE STUDY OF THE COTTON INDUSTRY IN HASKELL, TEXAS
}

\author{
Copyright @ 2003 \\ by the Texas Department of Transportation (TxDOT)
}

All rights reserved.

TxDOT owns all rights, title, and interest in and to all data and other information developed for this project under Contract \#572XXSA005. Brief passages from this publication may be reproduced without permission provided that credit is given to TxDOT and the author. Permission to reprint an entire chapter, section, figures, or tables must be obtained in advance from the Supervisor of the Historical Studies Branch, Environmental Affairs Division, Texas Department of

Transportation, 125 East $11^{\text {th }}$ Street, Austin, Texas 78701. Copies of this publication have been deposited with the Texas State Library in compliance with the State Depository requirements.

Printed by Accugraphics in Austin, Texas

May 2003

For further information on this and other TxDOT Historical Studies publications, please contact

Texas Department of Transportation

Environmental Affairs Division

Historical Studies Branch

Lisa J. Hart, Supervisor

Historical Studies Report No. 2003-02

Bruce D. Jensen, Series Editor

Production of this report was directed by

Prewitt and Associates, Inc.

Cultural Resources Services

Austin, Texas

Reports of Investigations, No. 138 


\section{TABLE OF CONTENTS}

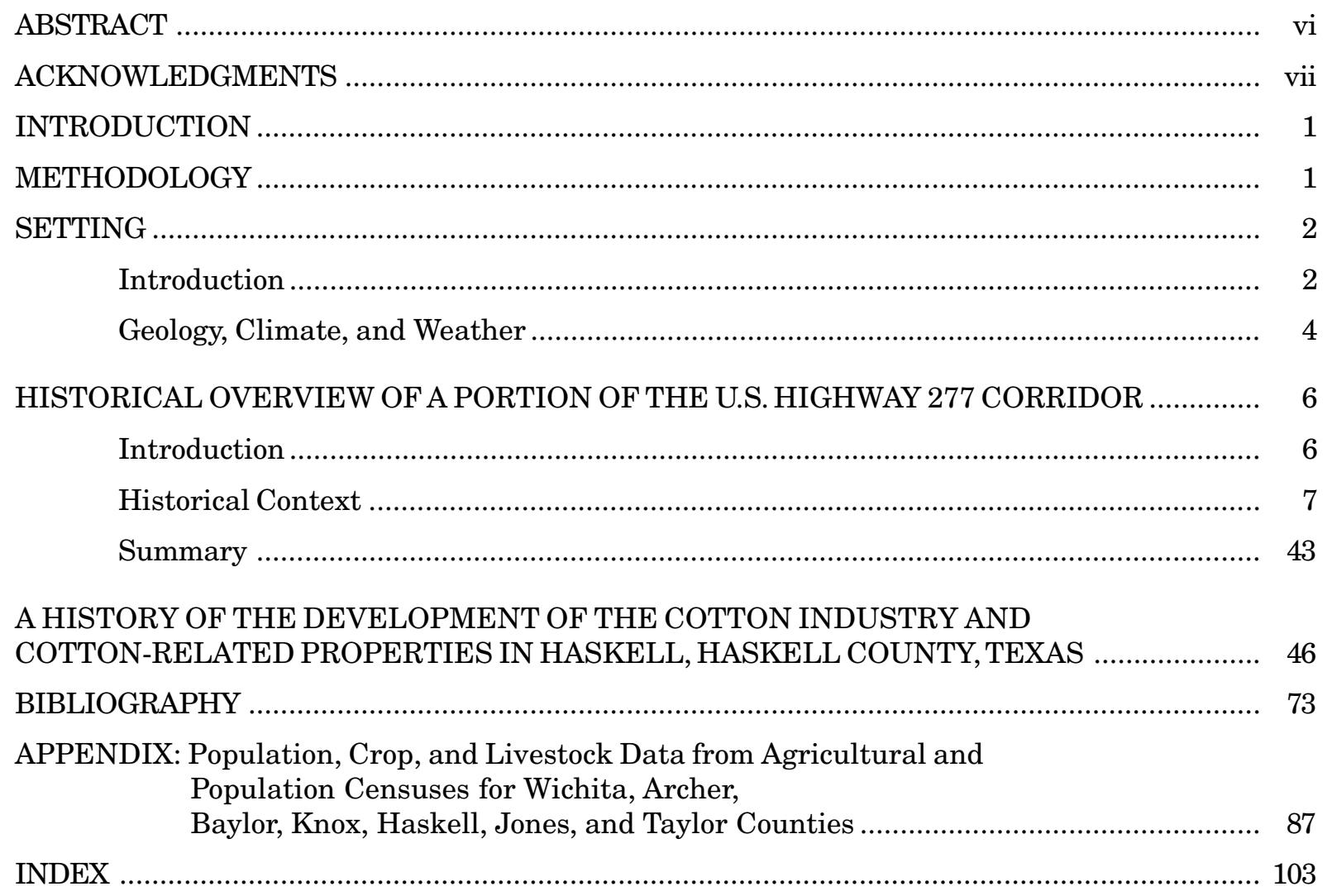




\section{LIST OF FIGURES}

1. Routes of the Wichita Valley Railway (1890), Wichita Valley Railroad (1905-1906), and Abilene \& Northern Railroad (1906)

2. Natural regions of Texas ..............................................................................................

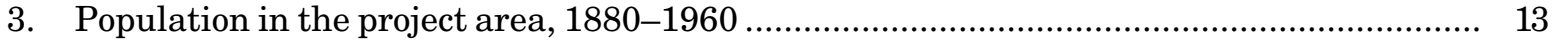

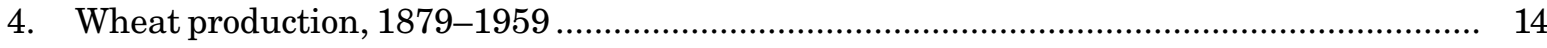

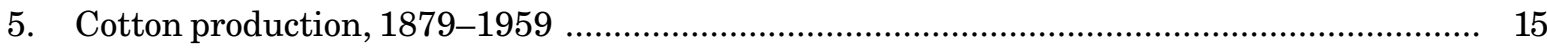

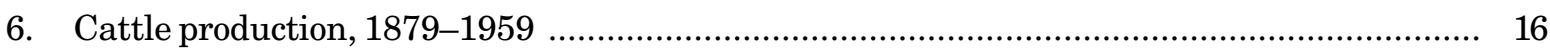

7. Rainfall and cotton production record for the Haskell County region .............................. 20

8. Sanborn maps of portions of Seymour, Baylor County, Texas, 1908 ............................... 21

9. Sanborn maps of portions of Haskell, Haskell County, Texas, 1908 ................................. 22

10. Sanborn maps of portions of Stamford, Jones County, Texas, 1908 .................................. 23

11. Sanborn map of portion of Anson, Jones County, Texas, 1908 ......................................... 24

12. Sanborn maps of portions of Seymour, Baylor County, Texas, 1916 .................................. 27

13. Sanborn maps of portions of Haskell, Haskell County, Texas, 1913 ................................... 29

14. Sanborn maps of portions of Stamford, Jones County, Texas, 1913 ................................ 30

15. Sanborn map of portion of Anson, Jones County, Texas, 1914 ......................................... 31

16. Numbers of farms and acres in farms in the project area, 1880-1960 ............................. 32

17. Sanborn maps of portions of Seymour, Baylor County, Texas, 1925 ................................. 33

18. Sanborn maps of portions of Seymour, Baylor County, Texas, 1925 ................................ 34

19. Sanborn maps of portions of Munday, Knox County, Texas, 1925 .................................... 35

20. Sanborn maps of portions of Haskell, Haskell County, Texas, 1921 ............................... 36

21. Sanborn map of portion of Anson, Jones County, Texas, 1922 ....................................... 37

22. Sanborn maps of portions of Seymour, Baylor County, Texas, 1930 ................................. 38

23. Sanborn maps of portions of Seymour, Baylor County, Texas, 1940 ................................. 39

24. Sanborn maps of portions of Seymour, Baylor County, Texas, 1940 ................................ 40

25. Sanborn maps of portions of Munday, Knox County, Texas, 1942 .................................... 41

26. Sanborn maps of portions of Munday, Knox County, Texas, 1942 ...................................... 42

27. Sanborn maps of portions of Haskell, Haskell County, Texas, 1931 ................................ 43

28. Sanborn maps of portions of Haskell, Haskell County, Texas, 1941 ................................ 44

29. Sanborn map of portion of Anson, Jones County, Texas, 1930 .......................................... 45

30. Sanborn map of portion of Anson, Jones County, Texas, 1939 ....................................... 45

31. Cotton-processing facilities in Haskell, Haskell County, Texas, ca. 1889-2002 .............. 56

32. Sanborn maps of the Haskell Oil Company Cotton Gin and W. T. McDaniel Cotton Gin ... 58

33. Sanborn maps of the Farmers Union Cotton Warehouse and McDaniel-Sanders Gin ........ 60 
34. Sanborn map of the Electric Gin Company on block 66

35. Sanborn maps of the Farmer's Co-Operative Society Gin No. 2 and The Farmers Gin Company and Haskell Electric Company Cotton Gins 65

36. Sanborn maps of the Harrison \& Herrin [Herren] Gin and Wair \& Dulaney Gin 66

37. Sanborn maps of cotton processing facilities in Haskell, 1949 68

\section{LIST OF TABLES}

1. Population, crop, and livestock data from the 1879 agricultural and 1880 population censuses

2. Population, crop, and livestock data from the 1889 agricultural and 1890 population censuses

3. Cotton processing facilities in Haskell, Haskell County, Texas, ca. 1889-2002 49

4. Population, crop, and livestock data from the Agricultural and Population Censuses for Wichita, Archer, Baylor, Knox, Haskell, Jones, and Taylor Counties 


\begin{abstract}
In February 2002, Prewitt and Associates, Inc., contracted with the Texas Department of Transportation, Environmental Affairs Division, to complete tasks describing the history and architectural resources of the U.S. Highway 277 Wichita Falls, to Abilene, Texas, corridor. Task 1 involved producing a broad overview of the corridor focusing on railroad construction and development of an agricultural landscape. The overview, constituting the first part of this report, provides a history of agriculture, transportation, and community development along the corridor, and identifies the forces at play in the development of the corridor that resulted in construction of specific properties. Task 2 involved creating a case study of Haskell focusing on the development of the cotton industry in the town and surrounding area, identifying the forces at play in the creation and growth of the town and agricultural and related industries, and briefly describing cotton-related cultural properties; this study constitutes the second part of this report. Task 4 resulted in an annotated bibliography pertaining to subjects associated with Task 1; the bibliography also appears in this report. The results of Task 3 , which involved producing an illustrated field guide to industrial property types, are more fully described in another volume.
\end{abstract}




\section{ACKNOWLEDGMENTS}

Recognition and thanks are due to the many individuals and institutions whose cooperation made possible the completion of this project. In Austin, the staffs of The Center for American History and Perry-Castañeda Library at The University of Texas at Austin, Texas State Library and Archives, and Secretary of State's office provided guidance to secondary sources, censuses, legislative records, and corporation files. In Lubbock, the staff of The Southwest Collection at Texas Tech University made important collections available and guided the author through the intricacies of the voluminous records of the Fort Worth \& Denver City Railway. The staff of the State Historical Society of Iowa promptly responded long-distance to requests for documents in the Grenville M. Dodge Collection.

Local assistance in Haskell, Texas, was outstanding. Mr. Leon Jones of the Haskell Cooperative Gin spent several hours patiently answering questions about the history of the cooperative. He also guided the historian through the gin, carefully explaining the processes in language that was understandable, even to a novice. The personnel at the Haskell County Appraisal District and Assessor's and County Clerk's offices were patient to a fault, providing access to early tax records and helping the historian locate some of the less-commonly used record sets in the basement of the clerk's office. Employees of the City of Haskell shared their carefully preserved copies of early city council minutes.

The historian also owes a debt of gratitude to the staff of Prewitt and Associates, Inc.: to Mr. Ross C. Fields and Ms. Audra L. Pineda for their critical reading of the manuscript, to Ms. Pineda for producing the report, to Ms. Karen M. Gardner for her production of statistical tables, and to Ms. Sandra L. Hannum for her inspired reinterpretation of those statistics into graphs, tables, and figures. Finally, thanks are due to Mr. Bruce Jensen at the Environmental Affairs Division of the Texas Department of Transportation and Mr. Bob Brinkman at the History Programs Division of the Texas Historical Commission for their guidance throughout the project and their helpful suggestions that brought focus and clarity to the research effort. 



\section{INTRODUCTION}

Work on Contract \#572XXSA005 (Work Authorization \#57204SA005) was undertaken for the Environmental Affairs Division of the Texas Department of Transportation (TxDOT) as part of an effort to mitigate the impacts of TxDOT's proposed rerouting of U.S. Highway 277 around Haskell, Texas. As a result of consultation among representatives of the Environmental Affairs Division, the History Programs Division at the Texas Historical Commission, and the project historian, a fivepart scope of work was developed. The purpose of the scope was to produce research documents that would be of use and interest to residents along the U.S. Highway 277 corridor (Task 1, historical overview; Task 2, a case study of Haskell and its cotton industry; and Task 4, an annotated bibliography of historical sources) and to staff of TxDOT and the Texas Historical Commission (Task 3, an illustrated, descriptive field guide to industrial property types in the U.S. Highway 277 corridor).

\section{METHODOLOGY}

Methodology associated with Tasks 1 and 4 (production of a historic overview of the corridor and an annotated bibliography of sources) started with a review of Diane Williams's historic context for a portion of the corridor prepared in 2000 for the TxDOT and of materials collected by Amy E. Dase for Task 3 of this project. The balance of the research occurred in Austin at the Perry-Castañeda Library and The Center for American History at The University of Texas at Austin. At the Perry-Castañeda Library, census records for the decades 1880 1960 and the years 1925, 1935, 1945, and 1955 were copied for Wichita, Archer, Baylor, Knox, Haskell, Jones, and Taylor Counties; and data pertaining to population, number of farms, amount of land in farms, and production records for wheat, corn, cotton, and cattle were abstracted. Research at The Center for American History focused on a review of county and local histories for the seven counties in the context area, using Williams's study as a starting point. A total of 33 county-level and 10 communitylevel sources were consulted. These ranged from genealogy-based treatments to general and institutional studies that identified economic and population trends from the late nineteenth century to the last quarter of the twentieth century. In addition, issues of the Texas Almanac that included community and county histories, and agriculture, oil, and transportation statistics were consulted. Histories of the Fort Worth and Denver-Colorado and Southern Railways and a biography of Morgan Jones also were used.

The historian contacted the State Historical Society of Iowa and requested copies of specific items of correspondence from the Grenville M. Dodge Papers. Staff at the Society forwarded documents from the period 1898-1907 that contained information about planning associated with construction of the Wichita Valley Railroad. The documents complemented those copied from the Fort Worth and Denver City Railway Collection in The Southwest Collection at Texas Tech University during Task 2 of the project.

Following the data-gathering phase, census information was organized in tabular and graphic forms to create a visual representation of trends along the U.S. Highway 277 corridor from 1880 to 1960 . Annotations required by Task 4 occurred concurrently with research associated with Task 1 . Sources were ranked by their usefulness to production of a broad overview of the context area as well as to histories of the development of communities, agriculture, transportation, and the oil and gas industry. As each source was used, the historian wrote descriptive remarks about the contents of the source and assessed its value to the project and potential interest to residents in the project area.

Research for Task 2, a case study of Haskell, Texas, focusing on the development of the cotton industry in the town and surrounding area, occurred in Austin, Haskell, and Lubbock, Texas. In Austin, collections of maps by the Sanborn Map Company at The Center for American History were copied in paper form and used to compile a preliminary list of industries in Haskell in 1908, 1913, 1921, 1931, 1941, and 1949. A limited number of issues of The Haskell Free Press were available on microfilm and were reviewed. The Center also had copies of all published histories of Haskell County. Those that focused on genealogical material were used to identify families, public institutions, and companies that were producers of cotton and cotton products. Research in Austin also occurred 
at the corporation division of the Secretary of State's office. Company names compiled from Sanborn maps, local history sources, and records in the Haskell County Courthouse were checked against corporation records, and data about incorporators, dates of incorporation, purposes of the businesses, shareholders, and other topics were copied.

Haskell County records at the offices of the city and county clerks, tax assessor, and appraisal district were voluminous and rich sources of data. All known companies associated with cotton-related activities were searched in the deed records, and their properties and relative values were recorded from block books available in the tax assessor's office. In addition, deed indexes, mechanics' liens, and chattel mortgage records on realty were searched to identify as many cotton-related businesses as possible, gather information about nonlocal companies with which Haskellbased companies had associations, and identify the periods when investment occurred. These records also were invaluable when it became evident that some Sanborn Map Company plats contained erroneous information. City council minutes were used to assess the extent to which city policies affected industrial development.

Because the city had renamed all of its streets sometime in the early to mid-twentieth century, effort was put into locating and copying accurate plat maps. These were used in conjunction with deed records and in the field to visit each cotton-related property in the vicinity of the historic Wichita Valley Railroad line through Haskell. Chains of title were compiled for each of those properties, and block books were reviewed for evidence of construction dates. Contact was made with the manager of Haskell's oldest continually operating cotton gin, and he was interviewed. A tour of the gin plant and associated structures was helpful in identifying the constituent parts of a typical facility.

In Lubbock, manuscripts in The Southwest Collection at Texas Tech University were used. The historian particularly focused on the papers of Morgan Jones, who was instrumental in the construction of portions of the Wichita Valley Railroad and invested in various local businesses; Seaman Asahel Knapp, who worked with agriculturists along the Wichita Valley line; Virgil Sonnamaker, whose collection included photographs of Haskell in the early twentieth century; and the Fort Worth and Denver City Railway, with particular use being made of microfilm rolls on which pre-1920 documents pertaining to the Wichita Valley Railway Company had been consolidated. The historian also made liberal use of The Haskell Free Press, targeting dates mentioned in Sherrill's 1965 history of Haskell County and in records examined in the Haskell County Clerk's records, but also looking at as many nonspecific dates as time would allow.

\section{SETTING}

\section{Introduction}

The project area includes parts of seven counties in the North-Central Plains region of Texas-Wichita, Archer, Baylor, Knox, Haskell, Jones, and Taylor-and stretches along approximately 150 miles of U.S. Highway 277. The counties are transected by the historic routes of the Wichita Valley Railway, which ran from Wichita Falls in Wichita County to Seymour in Baylor County beginning in 1890; the 1905-1906 Wichita Valley Railroad extension of the 1890 line from Seymour through the communities of Bomarton in Baylor County, Goree and Munday in Knox County, Weinert and Haskell in Haskell County, to Stamford in Jones County; and the 1906 Abilene \& Northern Railroad from Abilene in Taylor County to Anson and Stamford in Jones County, where it joined the Wichita Valley Railroad (Figure 1).

Linked by a historic railroad line that operated under the auspices of the Colorado \& Southern Railway Company, and by the moremodern U.S. Highway 277, the project area has a specific geographic identity, being part of the Permian Plains, a major subarea within the North-Central Plains. Stretching from the vicinity of Abilene in Taylor County to the Red River, the region is characterized by a topography with surfaces dominated by the deposition of materials brought in from elsewhere by erosion. Soils both support the growth of grasses preferred by livestock and form the basis for highly successful commercial plant cultivation.

The project area is typified by patterns of rainfall and drought that have made it only marginally reliable to agriculturists and commercial interests that have depended on livestock 


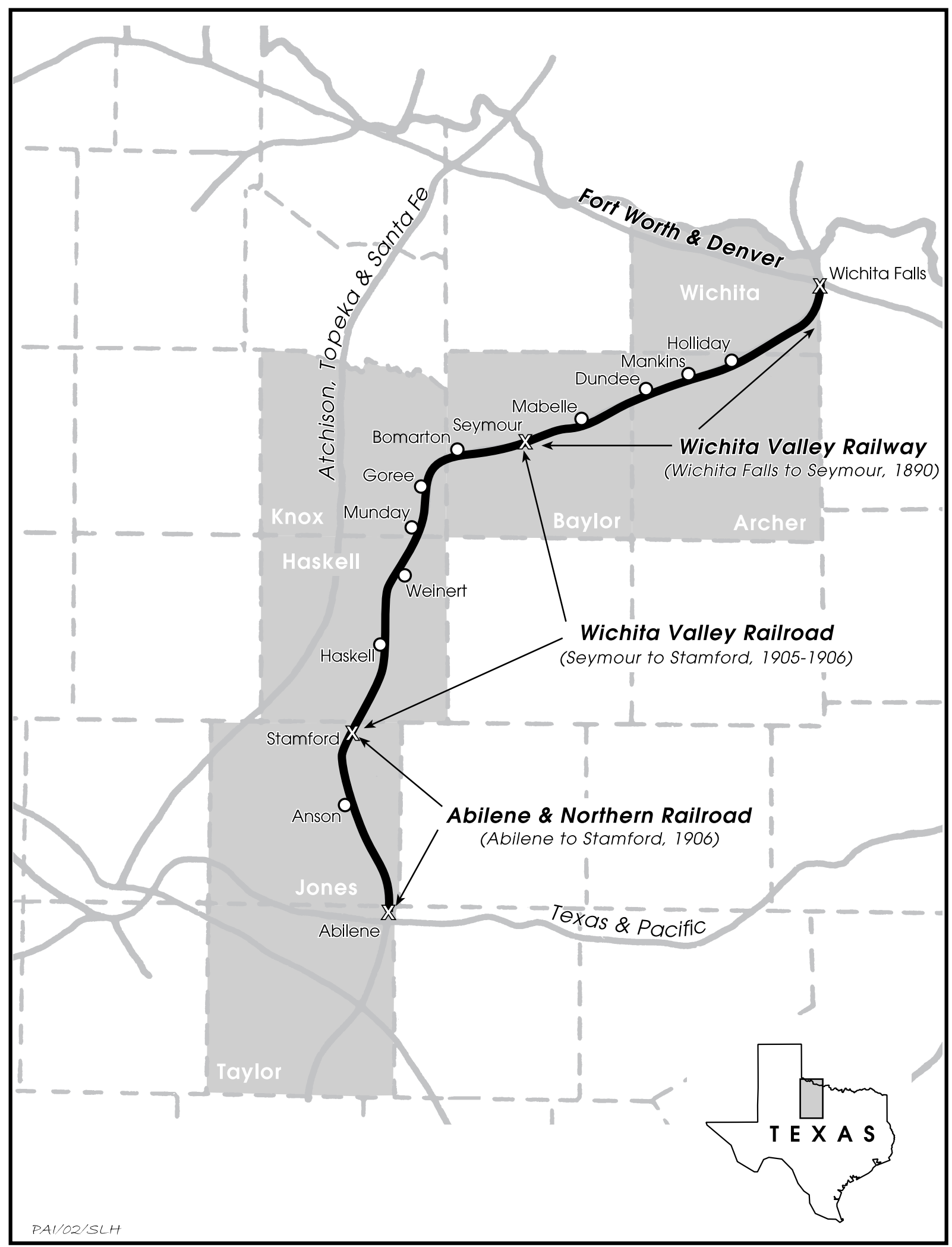

Figure 1. Routes of the Wichita Valley Railway (1890), Wichita Valley Railroad (1905-1906), and Abilene \& Northern Railroad (1906). 
and crop production for their success. The area also has a history of oil and gas production that has rivaled and, in some areas, far surpassed the impact of either railroad or agricultural development. While this impact has weighed disproportionately on the northern end of the U.S. Highway 277 corridor, all counties within the corridor from Wichita to Taylor have benefited from oil and gas production during the twentieth century.

\section{Geology, Climate, and Weather}

The project area, which runs from Wichita Falls in Wichita County to Abilene in Taylor County, is located in the Middle Texas Province as defined by geographer Elmer Johnson (1931:54, Figure 19) (Figure 2). This natural area includes the North-Central Plains, which are comprised of plains and low plateaus cut across by the Wichita and Brazos Rivers. Permian outcrops occur in the plains, and in some areas the land is comprised of silts and sandy silts that have been developed as "the important farming sections which extend from San Angelo by way of Abilene and Haskell to the Red river lowlands" (Johnson 1931:54-56). According to Johnson (1931:116), portions of the North-Central Plains are dominated by surfaces characterized by the deposition of materials brought in by agents of erosion (constructional surfaces), and these surfaces are important agriculturally.

Most of the project area is Permian and is characterized by constructional topography. It includes the region from Abilene (Taylor County) to Anson and Stamford (Jones County), Haskell and Weinert (Haskell County), Munday and Goree (Knox County), and Bomarton, Seymour, and Mabelle (Baylor County). This area is called the Abilene-Haskell Plains (see Figure 2) and is a subdivision characterized as well by a thick growth of short grasses that is desirable for grazing. Influenced by this growth and by a combination of rainfall and temperature conditions, the subdivision also is characterized by "a black colored soil, high in basic constituents, whose physical conditions of friability and mellowness allow it to be worked readily. This type of soil is a form of the famous 'Black Earth' group of soils which is so important in present-day commercial agriculture the world over" (Johnson 1931:117-118).
The balance of the project area, from Mabelle in Knox County to Dundee, Mankins, and Holliday in Archer County and Wichita Falls in Wichita County, is in the Red River Rolling Plains (see Figure 2). This area embraces rolling strips of country covered with alluvial and wind-blown deposits. Land north of the Wichita River is characterized by soils that sometimes are dark in color and are underlain with a heavy subsoil. Land south of the Wichita River is characterized by heavy, dark soils that make excellent grazing lands and are suitable for farming (Johnson 1931:122-123), like much of the Abilene-Haskell Plains to the southwest.

Land in the project area is conducive to large-scale farming and ranching because of the soil types there. The North-Central Region also is characterized by geologic formations that are the source of significant oil and gas deposits. While such deposits are found throughout the project area, the largest fields by far are in the northern portion where the Wichita/Wilbarger and Petrolia fields were the source of approximately 48 percent of all oil produced in Texas between 1911 and 1925 (A. H. Belo \& Company 1926:165). The presence of these deposits has had far-reaching implications for local and regional economies and frequently has mitigated the negative impacts of climate and weather.

The project area is climatologically marginal, at best, being in a zone identified as "critical." The seven counties receive an average rainfall of 23.59 inches per year in Taylor County in the extreme south to 27 inches per year in Wichita County in the extreme north (Hart 1996:952; Leffler 1996b:224). With an overall average of 25.14 inches of rain, the area is close to the 20 inches of precipitation identified by Webb as being marginal for agriculture that is carried on "by ordinary means ..." (Webb 1931:323-324).

Hardships created by marginal moisture are exacerbated by the recurrence of severe droughts. In Texas generally, the worst droughts in order of severity occurred in 1954-1956, 1916-1918, 1909-1912, 1901, 1953, 1933-1934, 1950-1952, 1924-1925, 1891-1893, 1937-1939, and 1896-1899 (Pool 1975:9). In the project area, the droughts of 1886-1887, ca. 1909-1911, and 1917-1918 were so severe that many of the counties lost much of their population; the impact of the 1950s drought on agriculture was 


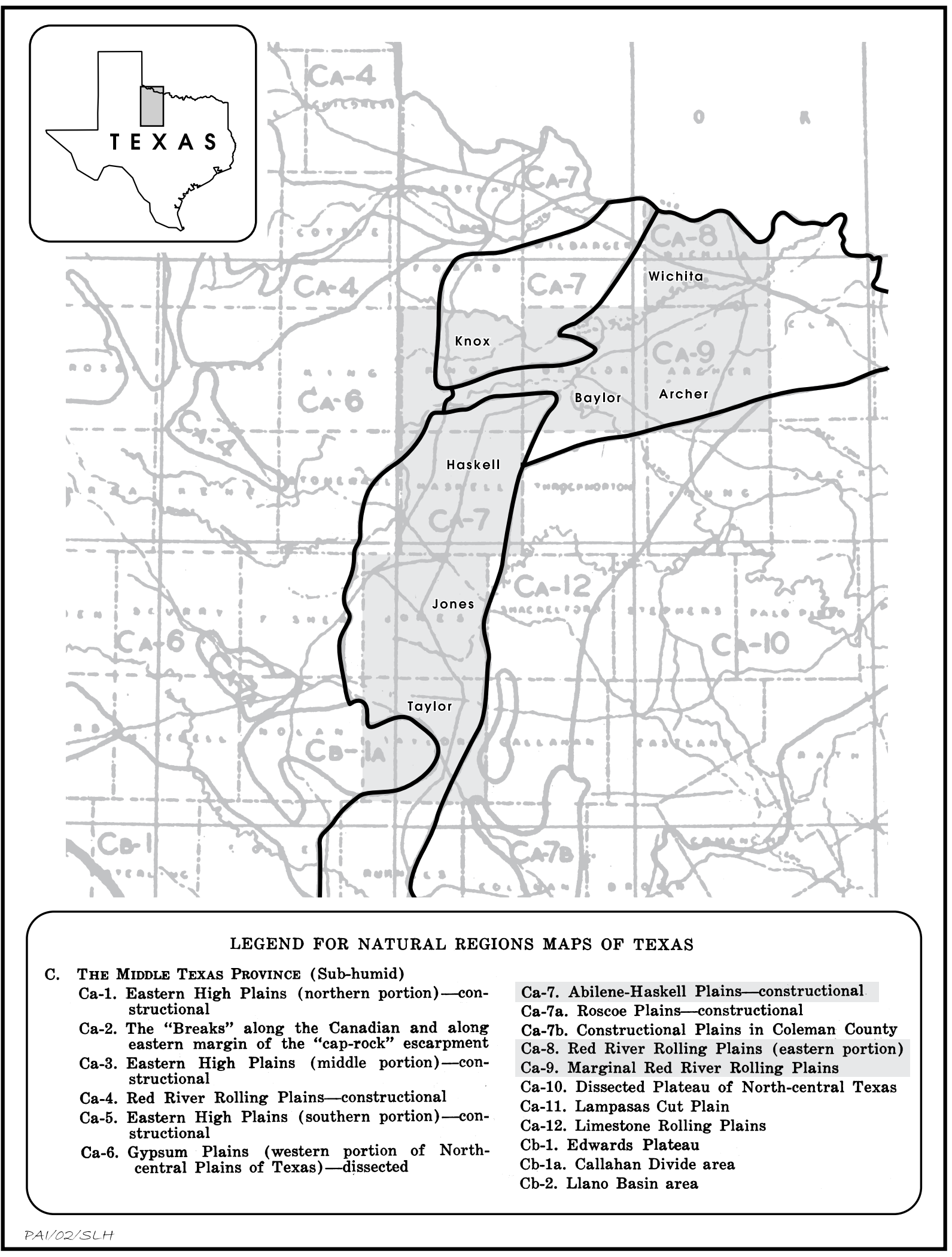

Figure 2. Natural regions of Texas. Johnson's map depicts the state's natural regions. The seven-county study area is comprised mostly of the Abilene-Haskell Plains to the south and west and the Red River Rolling Plains to the northeast. Figure taken from Johnson (1931:Figure 19). 
so devastating that the industry never recovered. Drought in the early 1890s and 1930s heightened economic problems engendered by a national panic and depression that were alleviated only by the strength of the oil and gas industries.

Plentiful rainfall at the right times of the year, on the other hand, created plenty for agriculturists and the merchants, bankers, suppliers, construction industries, and railroadmen who were dependent upon the success of crops and stock. As Frank Hastings of Stamford wrote in his crop letter of February 1915, favorable weather had resulted in cotton crops that inspired farmers to buy freely. They purchased not only agricultural implements but also furniture, dry goods, and clothing. Lumber was "moving" quite freely, and residents of town and country were repairing granaries, building storage sheds, building new homes, and adding on to older ones (Hastings 1915).

\section{HISTORICAL OVERVIEW OF A PORTION OF THE U.S. HIGHWAY 277 CORRIDOR}

\section{Introduction}

The project area includes portions of seven counties in north-central Texas-Wichita, Archer, Baylor, Knox, Haskell, Jones, and Taylor-that stretch along approximately 150 miles of U.S. Highway 277. The area is anchored at each end by two of the largest cities in the regionWichita Falls in the north and Abilene in the south-and the land in between is largely rural. The highway connects a series of small communities that serve as county seats and local trade centers.

Agriculture, transportation, and the oil and gas industries have shaped the project area's economic development, social organization, and building history. The counties and their communities have a common geography, geology, and climate and, as a result, also have a common social and economic heritage. Buffalo hunting and the cattle industry provided the impetus for early forays into the area, while railroad and highway construction defined mobility in the twentieth century. Both forms of transportation supported stock raising, crop cultivation, and the movement of people, goods, and energy resources into and out of the region.
Attracted to the region because of the communities and populations already there, the promise of agricultural productivity, and a sense of competition with other lines that threatened this particular trade territory, the Fort Worth and Denver City Railroad and its feeder lines penetrated the project area between 1890 and 1906. Thereafter, the fortunes of the railroad were dependent on the agricultural success of the project area, while the fortunes of late-nineteenth- and twentieth-century agriculturists were tied not only to the railroad but also to weather, markets, international events, government policies, and sources of supplemental income, such as oil and gas. Depressions or serious recessions spawned by national events, changes in markets, and severe droughts occurred in the mid-1880s, the early 1890s, 1909-1912, 19171918 , the mid-1930s, and the early 1950 s. Periods of economic prosperity, with their accompanying building booms, occurred during 1881-1885, 1887-1891, 1903-1908, 1913-1914, the 1920 s, sporadically during the $1930 \mathrm{~s}$, and in the 1940s. Particularly after the drought of the early 1950 s, populations stagnated or declined in rural areas but increased markedly in Wichita Falls and Abilene, farms declined in number but increased in size, production of wheat was strong, and farming populations turned again to livestock raising.

Promotion of the area to the railroads and potential immigrant communities is reflected primarily in architectural resources dating from ca. 1890-1910, while periods of unusual prosperity, often resulting from agricultural bounty, oil and gas development, or events associated with World War II when military facilities were built near major cities are reflected in architectural resources dating from ca. 1912-1914, 1919-1929, and 1940-1946 and beyond, if the communities were fortunate enough to retain the facilities.

With the advent of automobiles and trucks, and of long-distance telephone service, all of which became available before World War I, reliance on the railroad began to decrease. Construction of paved roads was relatively slow, the seven counties having an average of 84 miles of paved roads by 1925 (A. H. Belo \& Company 1926). But the development of a more-comprehensive system during the 1930s may have contributed to a stagnation or gradual loss of population in those counties lacking large cities (Archer, 
Baylor, Knox, Haskell, and Jones) and the steady growth of Wichita and Taylor Counties whose two large urban centers of Wichita Falls and Abilene continued to attract industry. A decline in population and agricultural production together with competition from trucking adversely impacted the Fort Worth and Denver City rail system in the project area. By the 1960s, rail service was cut back or discontinued, and the line was abandoned in the 1990s, at which time it was part of the Burlington Northern Railroad.

Continuing agricultural productivity in the project area has resulted in the on-going use of some historic buildings, despite an absence of rail service. Other historic properties have been abandoned or adapted to new uses. Those that remain reflect the area's development patterns. To understand what was built, why it was built, and how it was built, it is helpful to understand the broad historical trends that shaped the project area.

\section{Historical Context}

Euro-American interest in the project area began in the early 1850 s when the Texas legislature approved an act enabling the Texas Emigration and Land Company to survey a tract that became known as the Peters Colony lands and included portions of Archer and Baylor Counties. Within 2 years, surveyors also had surveyed tracts in present-day Wichita County, and an individual named Mabel Gilbert became the area's first semipermanent resident when he built a house on a bluff 10 miles north of present-day Wichita Falls in 1855 (Baylor County Historical Society 1972:2; Hart 1996:952; Kelly 1982:5).

Gilbert was driven from the area by Indian depredations the following year, but the creation of the seven counties by 1858 must have sparked some interest among potential settlers despite the risk of attack. Gilbert returned to Wichita County in 1859 where he was joined by the Tom Buntin family in the 1860s. On the other end of the project corridor, in Taylor County, William E. Cureton moved his cattle from Palo Pinto County into the area south and east of present-day Abilene (Anderson and Leffler 1996:1,150; Casey 1974:12; Graves 1996:427; Hart 1996:952; Hendrickson 1996:955; Kelly 1982:5; Leffler 1996a:501, 1996b:224; Lewis 1996:224; Odintz 1996:994).

Immigration to the project area spread more evenly along the corridor in the early to mid1870s. Silas Baggett and John B. Gholson settled in Archer County in 1868-1869, while C. C. Mills settled in Baylor County in 1870 . Daniel and Tom Waggoner moved to Wichita County in 1871, and the 99 Ranch built its headquarters in Archer County about the same time, as did Will Ikard and E. F. Ikard who set up the Circle Ranch. An early settlement started in Jones County near the abandoned Fort Phantom Hill site in 1872; and Creed, John, and Emett Roberts, and Mode Johnson and J. G. Johnson established ranches in the same area in 1873. To the south, buffalo hunters in Taylor County included prospective settlers such as James W. Holmes, John B. Clack, and A. J. Tucker (Anderson 1996c:786; Baylor County Historical Society 1972:2; Duff 1970:30; Graves 1996:427; Loftin 1979:96; Odintz 1996:994; O'Keefe 1969:3-4).

The successful conclusion of the Red River War of 1874-1875 created the impression that the Texas plains west of the burgeoning city of Fort Worth were open for settlement and the cattle industry. Agriculturists such as R. O. Prideaux settled in Archer County, J. W. Stevens and C. C. Mills in Baylor County, and John Simpson and his Hashknife outfit in Taylor County. About the same time, groups of farmers were attracted to the area, including the W. W. Hutton family from Canada who arrived in Archer County in 1875 and not only raised sheep but also put in a few acres of farmland. A community of nine families congregated in the Round Timbers community of Baylor County, and J. R. McClain led a group of farming settlers from Oregon to the present-day site of Seymour, also in Baylor County (Baylor County Historical Society 1972:3; Duff 1970:34; Graves 1996:427; Lewis 1996:224; Loftin 1979:94-95).

Intensification of interest in the project area from ranchers, primarily, and farmers, secondarily, and the beginnings of nascent communities were accompanied by the establishment of formal towns. In the south, the town of Buffalo Gap in Taylor County began to emerge as a trade center, while the townsite of Wichita Falls at the opposite end of the corridor was platted in 1876. No doubt its few inhabitants looked to Fort Worth some 120 miles to the southeast where the arrival of the Texas \& Pacific Railroad 
in July 1876 signaled a turning point in the destiny of that city and of the region to the west and southwest. Within a year, Fort Worth's population had reached 6,000 , and traders headquartered there extended operations into the Panhandle to capture business that previously had gone to Kansas. The agricultural trade boomed as well, and a new cotton compress and grain elevator were constructed in Fort Worth in 1878. According to Overton (1953:37), "trade in lumber broke all records."

The Texas \& Pacific stalled in Fort Worth, and construction of the Fort Worth and Denver City, which had been chartered by the Texas legislature in 1873 to create a connection between Denver and the Gulf of Mexico by way of Fort Worth, was delayed by the Panic of 1873 . Nonetheless, immigration by ranchers and farmers to the project area continued. By 1877, Taylor County to the south had a population of ca. 100, and the following year, when 200 Russian immigrants attempted to colonize land on Lytle Creek, the county became an independent, organized entity with its population clustered around Buffalo Gap. Two counties north, George T. Reynolds and John A. Matthews established a ranch on California Creek in Haskell County, and Thomas F. Tucker joined them in 1879. Shortly after, W. R. Standifer brought a flock of sheep to Willow Springs at the future location of the town of Haskell (Billingsley 1996:1,125; Duff 1970:34-37; Leffler 1996a:501; Overton 1953:35; Spence 1971:55; Werner 1996a:847).

In Knox, the next county north from Haskell County, W. M. Gulick and Ham Colthrop settled on Knox Prairie, bringing a herd of cattle with them. Baylor County, which was immediately east of Knox County, was more heavily populated and formally organized in 1879 with Seymour as the county seat. But relations between ranchers and farmers there, as in neighboring Archer County, were highly contentious. Cowboy employees of the Millett Brothers, who had moved to Baylor County from Guadalupe County, attempted to run farmers off of their holdings, and rancher opposition to a movement for political organization by farmers and smallscale ranchers delayed county designation of Archer for a year, until 1880 (Baylor County Historical Society 1972:4-5; Graves 1996:427; Hunt 1996:983; Knox County History Committee 1966:101-102; Lewis 1996:224).
By 1880, the seven counties in the project area had become attractive to ranchers who sought open range and farmers beginning to exploit the prairie's fine black soils. But counties differed greatly in population. Probably because of the immediate promise of a railroad, Taylor with its 1,736 individuals was by far the most populous, having approximately more than double the number of residents in Baylor County (Table 1). Baylor's large population relative to the other five counties probably was the result of the extraordinary promotional efforts carried on by land companies such as The Western Land Company, which had moved its headquarters from Weatherford to Seymour by 1880. From its new location, the company advertised Baylor County land to land agents, correspondents, speculators, tourists, immigrants, and homeseekers. It promised that Seymour, which supposedly had seven rail lines headed its direction and probably would attract the Texas \& Pacific, would become the "largest city southwest of St. Louis, Missouri." Indeed, if Grant were elected president, and if the states elected Republican senators, and if the Texas legislature could be induced to divide Texas into two parts, then Seymour would become the capital of the new state of Mexicano. There was enough water to support large-scale agriculture, and The Western Land Company promoted the suitability of the area to cultivation of wheat. Local farmers were said to be sowing large acreages in wheat, and the company predicted that in fewer than 10 years there would be "forty large flouring mills located here on the Wichita river." Seymour would become a veritable Minneapolis with "30,000,000 acres of wheat land to support it" (The Western Land Company [1880]:2-3, 6-7, 14-15).

Taylor and Baylor Counties experienced considerable growth by 1880 , and Wichita, Archer, and Jones Counties were not far behind, the last because it was considered a contender for the Texas \& Pacific Railroad route. Knox and Haskell, the two counties most remote from any rail potential, on the other hand, had populations of only 77 and 48 . Similarly, they had by far the smallest number of farms and the least amount of land in farms, and they produced no wheat or cotton, crops that had already begun to appear in the 1879 agricultural census for Wichita, Archer, Baylor, Jones, and Taylor Counties (see Table 1). 


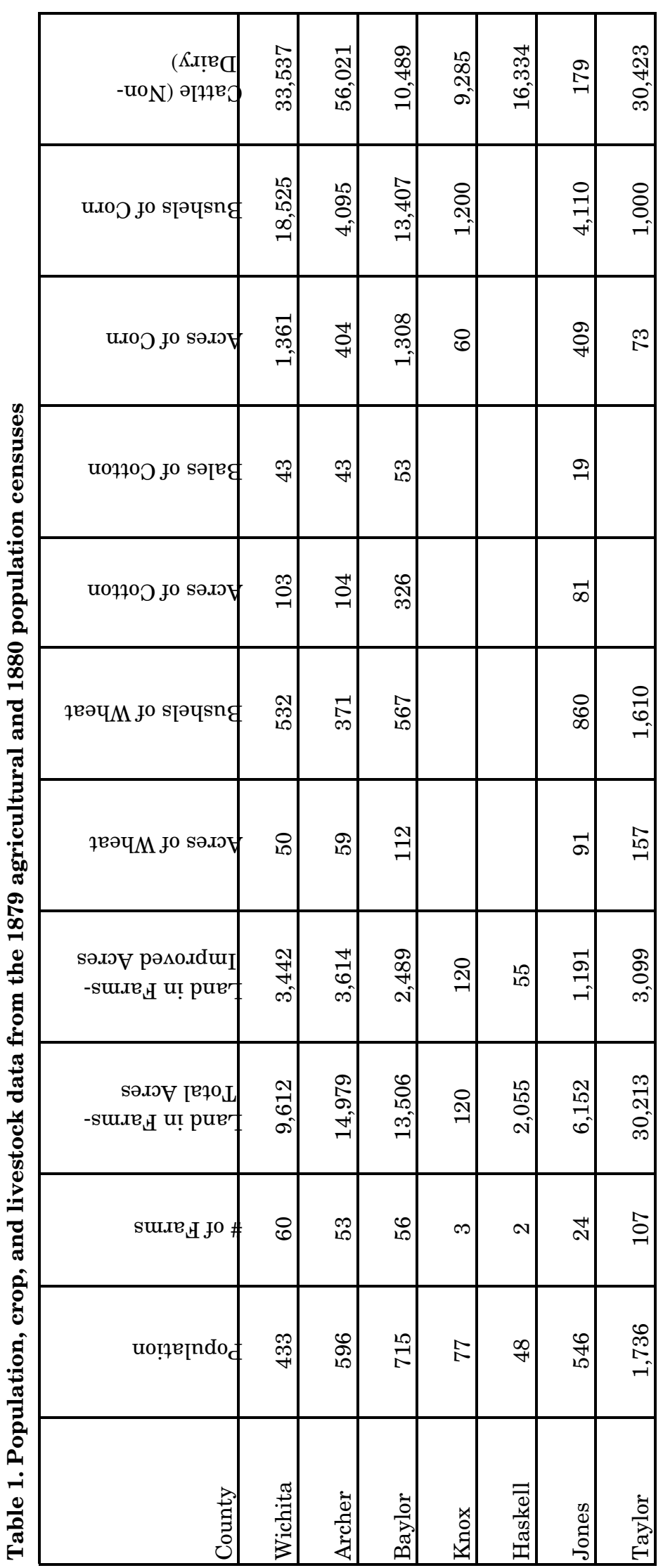


Thanks to rail construction through the northernmost and southernmost portions of the project area, the accompanying promotional efforts by railroads and townspeople, and beneficial weather conditions, the period from 1881 to 1885 encompassed the first boom years for the seven-county region. In 1880, an eastern combine headed by Jay Gould had taken control of the Texas \& Pacific Railroad Company and had hired General Grenville M. Dodge to head construction. Dodge identified the most desirable route as being through country that, "when settled is capable of supporting its local trade." He therefore directed surveyors to "note carefully the quality and capacity of the agricultural, grazing and mineral capacities of each townsite and county." By March 1881, the Texas \& Pacific had reached the new Abilene townsite, which the railroad had promoted through an extensive advertising campaign as "The Future Great City of West Texas." By July, the town had approximately 50 businesses and 800 residents, and the local newspaper touted the communities as "the natural market for all of Jones county and north of that" and the region as one that was evolving from exclusively stock country to farming country. While production of wheat and cotton remained modest, resident John Estes was sufficiently sure of the grain and cotton crops growing in surrounding counties to build the Abilene Flour and Grist Mills and Cotton Gin by 1884, the same year the town began to hold fairs to promote the region's agricultural products (The Abilene Reporter 1884:14-15; Downs 1996:8; Duff 1970:49, 51, 57, 59-60).

At the northern end of the project area, Wichita Falls was about to become the terminus for another rail line. In April 1881, Grenville Dodge contracted to build the Fort Worth and Denver City line northwest from its terminus in Fort Worth, and by July 1881, the rails reached Wichita Falls, 1 month after Wichita County was organized. The first train pulled into the depot at the town, bringing with it prospective settlers from Fort Worth and points east who hoped to buy city lots. With their arrival and the creation of a major railhead, farmers gradually became more of a force in the surrounding region. Able to plant crops for more-distant markets, the farmers and stockmen of the Wichita County area, like those to the south in Taylor County, began to abandon subsistence farming. Interest in cash crops such as wheat and cotton increased, and the availability of barbed wire encouraged the introduction of blooded stock (The Abilene Reporter 1884:14-15; Bureau of Business Research 1949:1.03; Duff 1970:43-44, 102; Hendrickson 1996:955; Kelly 1982:20; Laxson 1958:n.p.; Odintz 1996:995; Spence 1971:52, 68, 76; Wichita Falls Chamber of Commerce [1908?]:2).

Completion of rail lines in the general area encouraged immigration to and growth of the five "interior" counties, as well. Archer and Jones Counties organized, and Robert D. Goree in Knox County opened up lands formerly used for grazing to farming, encouraging immigrants from other states and Texas counties to come there and farm. The community around Rice Springs flourished and was renamed Haskell in 1882; 3 years later, the county organized. To the south, Swante M. Swenson established the Ellerslie Ranch in Haskell and Jones Counties and Ericsdahl Ranch in Jones County east of present-day Stamford. Dedicated to the improvement of livestock, Swenson also was interested in the benefits that might accrue from opening range land to farming (Anderson 1996b:738; Leffler 1996a:501; Lewis 1996:224; Odintz 1996:994-995).

The promise of prosperity created by rail service via the Texas \& Pacific through Abilene and the Fort Worth and Denver City to Wichita Falls was interrupted between 1885 and 1887 by weather events that decimated livestock in the region. A bitterly cold winter in 1885-1886 that was repeated in 1887 killed thousands of cattle, and a number of ranches went bankrupt. A drought that began in February 1886 and lasted until July 1887 followed the first severe winter. Creeks and rivers went dry, and vegetation was nonexistent. Calls for help solicited a carload of meal, flour, and bacon from St. Louis as well as a visit from Red Cross representative Clara Barton. Fort Worth and Denver City president Morgan Jones reminisced about the disaster of 1885-1887, when the countryside along the railroad's route had "suffered its most protracted drought in memory, crops were a total failure, there was not enough grain produced to seed the land, grass and water on the pasture lands dried up, beef cattle did not fatten, and settlers ceased coming to the area." His plan to alleviate the suffering by donating seed to the farmers and hiring as many of them as 
possible until the next planting season had only limited success, and counties such as Archer lost population (Baylor County Historical Society 1972:5; Duff 1970:104; Graves 1996:427; Gray 1963:117; Lewis 1996:224; Loftin 1979:105, 107; Spence 1971:85-86).

The drought of the mid-1880s ended with flooding rains in 1887 , and the change in weather, together with Morgan Jones's tireless promotion of the area, resulted in bumper crops for several years and a flood of new immigrants. Growth resumed in Archer County, and people moved into adjacent Baylor County as well, where the 1889 wheat crop was outstanding. More settlers moved to Knox County and established the town of Goree in 1887. Nearby, two farmers-M. L. Arnolds and A. Parksplanted a cotton crop that they had to haul to Albany and Wichita Falls for ginning. J. F. Bolander near present-day Munday in Knox County, who also made his first cotton crop in 1887, hauled it to a gin in Abilene, 80 miles distant. That city organized its own major promotional effort the next year with the formation of the Abilene Progressive Committee, which published booklets describing the glories of the Abilene region (Baylor County Historical Society 1972:6; Britton 1955:17; Duff 1970:168-169; Gray 1963:69; Jenkins 1996:252; Knox County History Committee 1966:104; Leffler 1996a:1,150; Lewis 1996:224; Munday Historical Society 1981:16).

The reversal of fortunes for the project area after 1886 was so remarkable that Morgan Jones's 1888 annual report boasted of the region's wheat production, increasing cattle shipments, and new immigrants who had responded to the Fort Worth \& Denver's advertising program. The next year, Jones was sufficiently impressed by the area's growth to urge Grenville Dodge to consider building a branch line to Seymour. Convinced of the agricultural richness of Baylor County and of the Abilene area, and concerned that the Missouri, Kansas and Texas Railroad, or the Rock Island Railroad would move into the territory, Jones offered to furnish one third of the funds needed for the 50-mile project (Spence 1971:120, 125$126,128 \mathrm{n}$ ).

New immigration after the disastrous weather of 1885-1887 had been encouraged, as well, by organizations such as the Abilene Progressive Committee (later the Abilene Board of Trade) and the Wichita Falls Country Emigration Association, which published a brochure about the assets of the area tributary to Wichita Falls. For the purposes of the promotional effort, Wichita Falls considered its distribution and trade territory to include nearby counties and towns (Archer County and Seymour in Baylor County) as well as more-distant areas (Knox County and Haskell in Haskell County). Wheat was identified as the staple money crop; and the availability of transportation on the Fort Worth \& Denver Railway meant that farmers had access to markets in Colorado, Texas, and the southeastern states. Such promotions bore fruit, and by 1889 new communities in the project area included Mankins and Holliday in Archer County (Duff 1970:168-169; Lewis 1996:485; Loftin 1979:227-228; Wichita Falls Country Emigration Association [ca. 1889]).

By 1890, censuses for the seven counties in the project area showed remarkable growth, much of which had occurred after the recordbreaking winters and drought of 1885-1887 and before construction of secondary rail lines between the Fort Worth and Denver City and the Texas \& Pacific (Table 2; Figure 3). Taylor County, with 6,957 individuals, had the largest population, followed by Wichita County with 4,831 , Jones County with 3,797, Baylor County with 2,595, Archer County with 2,101, Haskell County with 1,665, and Knox County with 1,134 . The county with the greatest rate of growth during the 1880s was Haskell, which grew by a factor of 34.69 . But population clearly remained weighted toward the counties that had railroad lines through them (Wichita and Taylor) or were in close proximity to those lines (Archer, Baylor, and Jones) (see Figure 3). The 1889 agricultural schedules expressed the popularity of wheat at this time, which found its largest production in Wichita, Baylor, Jones, and Taylor Counties (Figure 4). Cotton production had its largest production in Jones and Taylor Counties (Figure 5), while the greatest amount of cattle production occurred in the two northernmost counties-Wichita and Archer (Figure 6).

The good weather that had boosted immigration in 1887-1889 continued in 1890, the year Grenville M. Dodge and Morgan Jones chartered the Wichita Valley Railway Company. Prohibited by the charter of the Fort Worth and Denver City from building branch lines, the two 


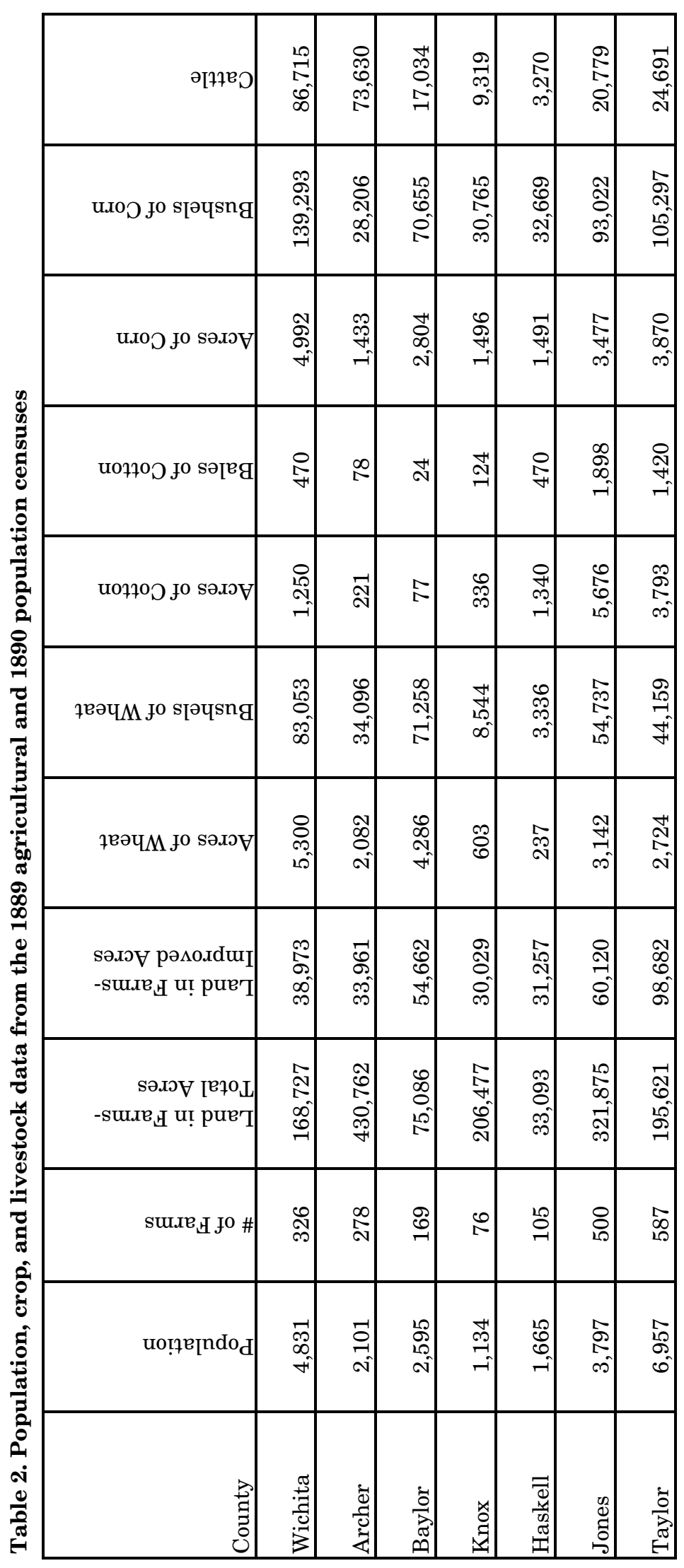




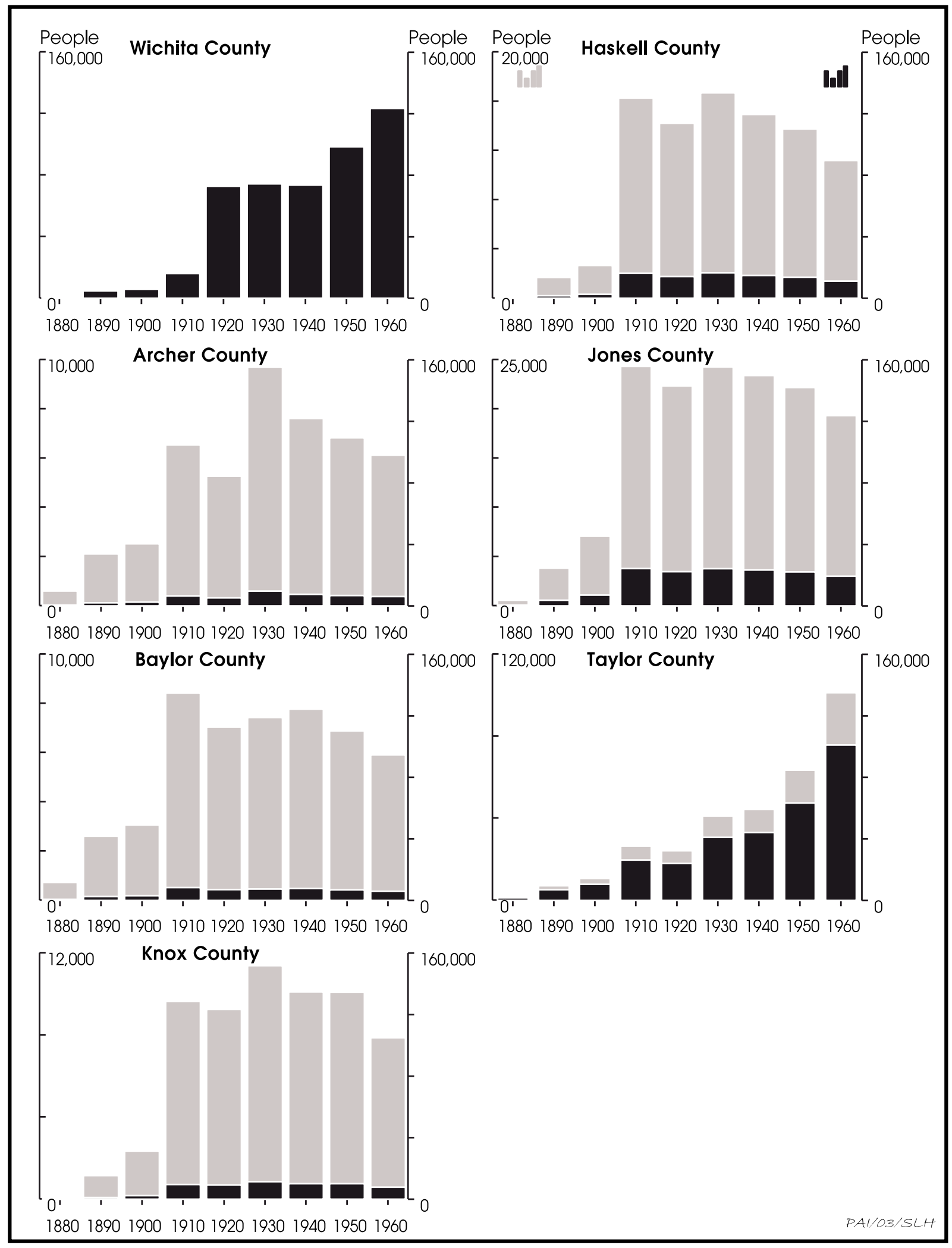

Figure 3. Population in the project area, 1880-1960 (data from decennial censuses). Black bars are relative to vertical axes on the right, which have a constant maximum value (for comparisons among counties). Gray bars are relative to vertical axes on the left, the maximum values of which are controlled by the population figures for each county (for looking at time-related trends within counties). 


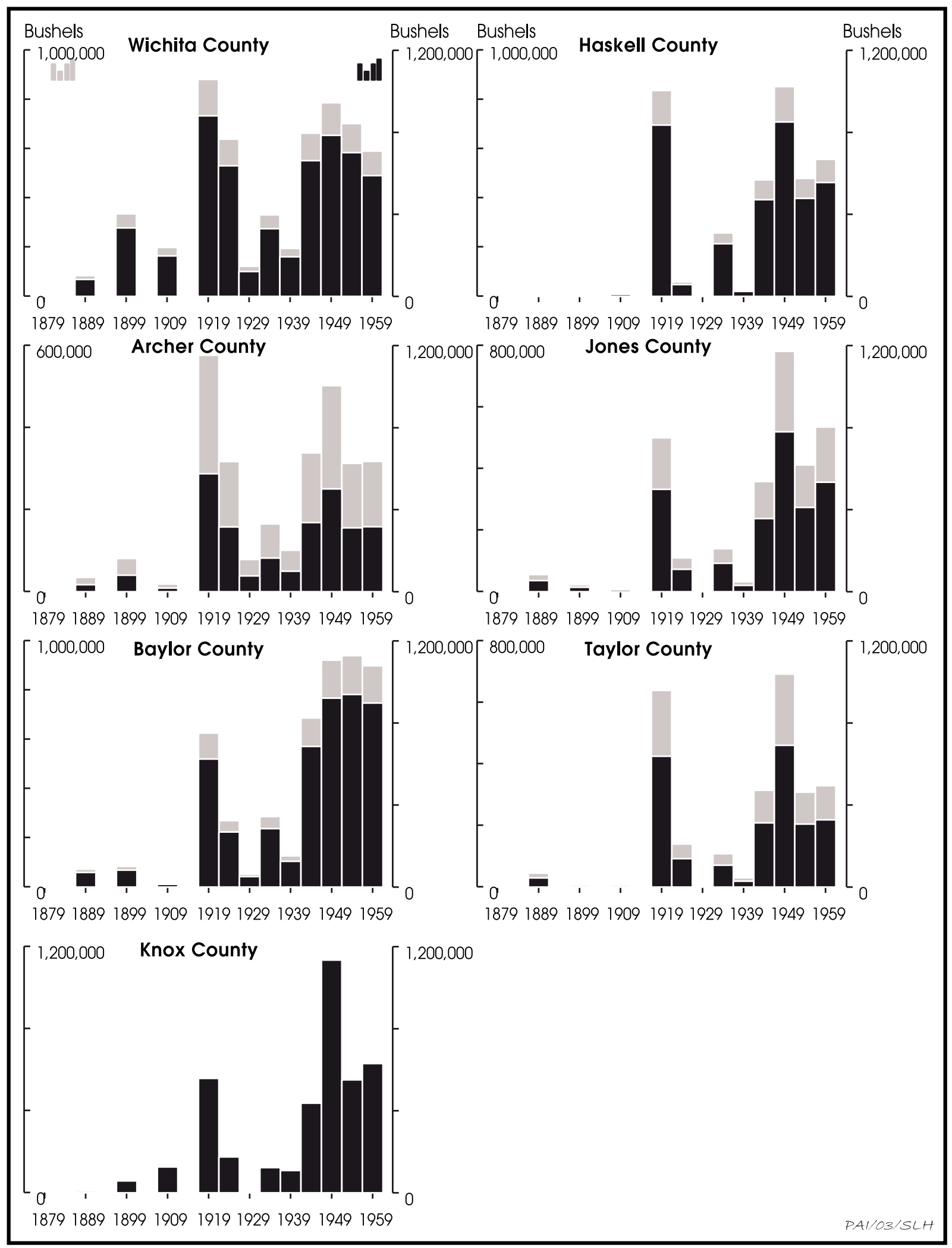

Figure 4. Wheat production, 1879-1959 (data from decennial and interdecennial agricultural schedules). Black bars are relative to vertical axes on the right, which have a constant maximum value (for comparisons among counties). Gray bars are relative to vertical axes on the left, the maximum values of which are controlled by the production figures for each county (for looking at time-related trends within counties). 


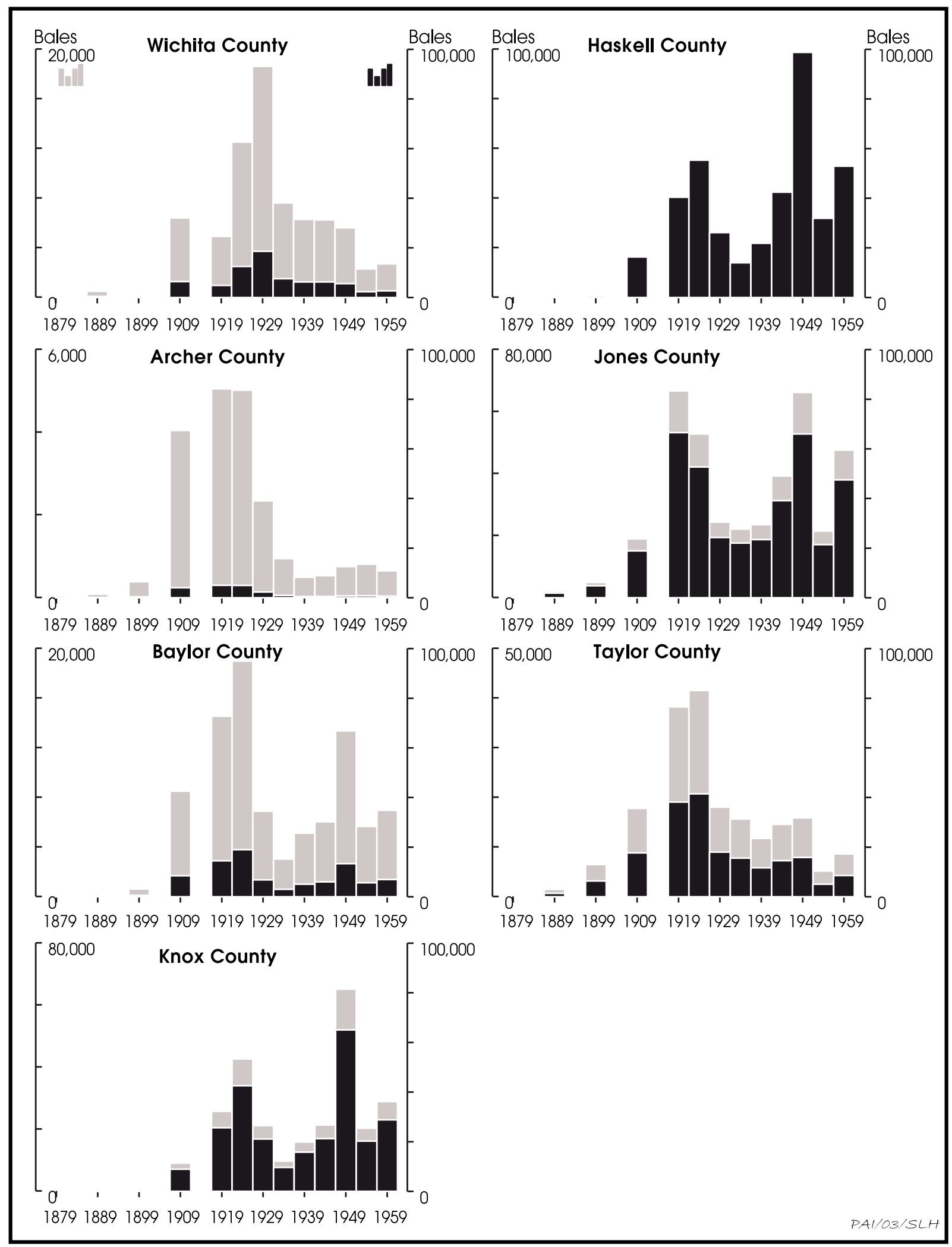

Figure 5. Cotton production, 1879-1959 (data from decennial and interdecennial agricultural schedules). Black bars are relative to vertical axes on the right, which have a constant maximum value (for comparisons among counties). Gray bars are relative to vertical axes on the left, the maximum values of which are controlled by the production figures for each county (for looking at time-related trends within counties). 


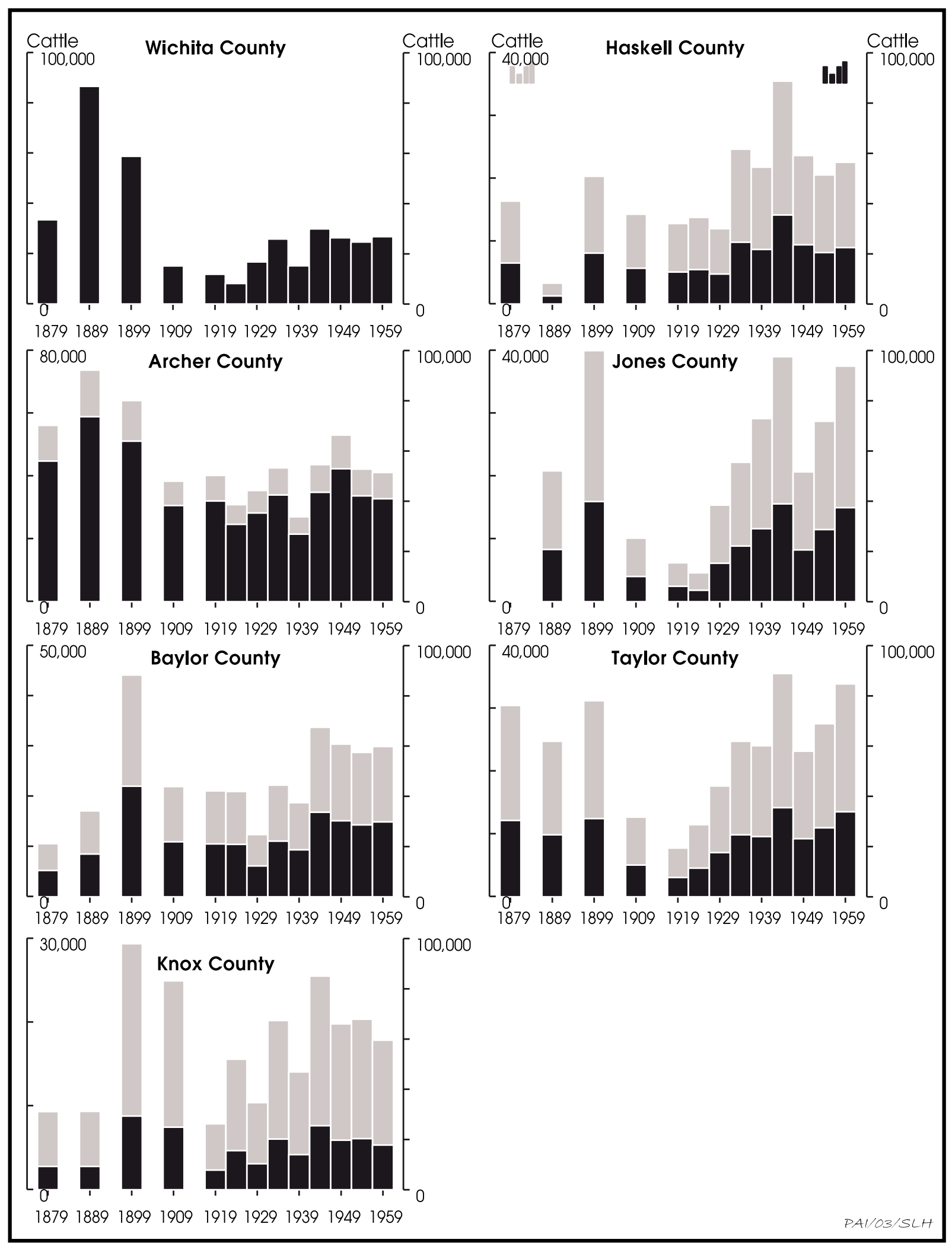

Figure 6. Cattle production, 1879-1959 (data from decennial and interdecennial agricultural schedules). Black bars are relative to vertical axes on the right, which have a constant maximum value (for comparisons among counties). Gray bars are relative to vertical axes on the left, the maximum values of which are controlled by the production figures for each county (for looking at time-related trends within counties). 
men were determined to charter the Wichita Valley, which would serve as a feeder line to the Fort Worth \& Denver City. Such a line would be desirable for the traffic it bore into and out of an agricultural area that had already proven itself productive and as protection against invasion from competitive lines. The communities that hoped to profit from the new line raised $\$ 50,000$ to encourage construction, and Seymour, particularly, went on a building spree. Property values soared there, and investors borrowed heavily, initiating construction projects. State legislation pricked the bubble, however, and loan companies withdrew their support, leaving numerous buildings unfinished. By August 1890, when the Wichita Valley Railway Company train rolled into Seymour, the boom was essentially over, despite heavy advertising in the Fort Worth Daily Gazette that touted the potential of "The Great Wichita Valley" (Cravens 1996:960; Hunt 1996:983; Overton 1953:259-160).

Morgan Jones himself anticipated a rush of new immigration to the Wichita Valley along the new line, and he organized the Western Industrial Company with Dodge, G. P. Meade, W. F. Somerville, and John Grant Jones for the purpose of marketing 150,000 acres in Archer and Baylor Counties. On a smaller scale, land agent R. D. Goree promoted Knox County as the "finest country on earth for diversified farming and stock raising." In Wichita Falls, investors Joseph A. Kemp and Frank Kell, who had contributed significantly to the growth of the city, saw an opportunity to extend the influence of Wichita Falls along the new rail line and into a productive farming area. With the construction of a new terminus at Seymour, the two men had a grain elevator built and bought wheat in Baylor, Knox, Haskell, and Throckmorton Counties (Baylor County Historical Society 1972:45; Goree [1890s]:n.p.; Spence 1971:129-130).

With improved transportation and good weather, wheat production increased in the project area during the early 1890 s, and investors constructed new facilities to handle the crop. By 1892, Wichita Falls had three flour mills, and Seymour was the location of the new McMillan Elevator near the railroad tracks. Growers began to pay increasing attention to cotton cultivation, as well, and the Seymour Monitor recorded an early Baylor County cotton crop in September 1891 (Britton 1955:24;
Kelly 1982:87; Sanborn Map Company 1892).

The early years of operation for the Wichita Valley Railway Company were profitable. But drought returned to the region in 1892 and persisted until the mid-1890s, creating economic hardships that were exacerbated by the national Panic of 1893. According to Overton, virtually all the principal crops in the territory of the Fort Worth and Denver City Railroad and the Wichita Valley Railway Company failed for 5 successive years. Revenues from crop production dropped precipitously, and immigration and development of new communities almost ceased. New building came to a standstill, reducing the movement of lumber and other building materials. The cattle trade was hard hit, and cotton production suffered as well. In October 1893, the Fort Worth and Denver City went into receivership (Britton 1955:17; Overton 1953:331332; Spence 1971:139).

Responses to the hard times focused on relief and experimentation. Realizing that farmers might need to modify their techniques, the state established an experimental farm about 1.5 miles from Wichita Falls where the owner, John W. Phillips, planted wheat, corn, cotton, grasses, oats, rye, barley, beans, hemp, and other crops. Presaging the Campbell method of dry farming, Phillips "recommended plowing deep and stated that he had made a fair crop every year since the drought of 1886." Another response recognized the need to secure more reliable water resources, and farmers between the Wichita and Brazos Rivers began to make surveys and raise funds for irrigation. For its part, the railroad distributed 16,000 bushels of wheat to farmers, taking a mortgage on their crops as security. Officers such as Grenville Dodge used the opportunity to urge diversification so that the failure of a crop such as wheat would not result in the collapse of the regional economy (Kelly 1982:17; Overton 1953:347-348).

A repeat of wretched weather in spring 1896 destroyed wheat, corn, and oat crops, and hundreds of farming families abandoned the land. Livestock that had been fed cotton and cottonseed in Knox County were driven to Indian Territory, Kansas, and beyond. Nonetheless, Morgan Jones managed to bring the railroad through receivership, and the Fort Worth and Denver City Railway Company regained control of its property in October 1896 (Overton 1953:349, 351). 
The end of the railroad's legal woes was accompanied by a significant improvement in the regional weather patterns that lasted for a decade. Revenues for the full year 1896 touched a decade-long low point, but rain returned during winter 1896-1897, and spring crops promised excellent yields. By the end of 1897, recovery was in full swing with grain production burgeoning and cotton cultivated in increasing amounts. The next year was even more encouraging, and with railroad receipts on the rise, Jones remarked on the inextricable linkage between the prosperity of the railroad and "sufficient rainfall." He also began to express an interest in building another feeder line to the Fort Worth and Denver City (Overton 1953:352; Parfet 1956:20; Spence 1971:143).

With agricultural prosperity came building projects. Agriculture-related improvements in towns and cities along the project area included a broom company in Holliday (Archer County); a grain mill, elevators, gins, and cotton platform in Seymour; a gin in Bomarton (Baylor County); a gin, mill, and elevator in Munday (Knox County); a cotton gin in Stamford (Jones County); and a cotton gin in Abilene (Baylor County Historical Society 1972:37; Gray 1963:35, 115; Hunt 1996:886; Kelly 1982:87; Knox County History Committee 1966:23; Sanborn Map Company 1904; Spence 1971:162; Zachry 1980:62).

Agricultural prosperity and the construction of facilities to process crops were accompanied by improvements to urban infrastructure. By 1897, H. D. Hockersmith had started construction of Seymour's first telephone line. Three years later, Stamford installed electric lights, and Abilene got a second telephone system that supplemented the one installed in 1895. By 1905, the city's water and electricity systems had been consolidated into the Abilene Light and Water Company (Baylor County Historical Society 1972:7; Downs 1996:9; Duff 1970:171; Spence 1971:162).

Finally, while large-scale exploitation of the resource was still a decade away, the first showings of oil had appeared in the Wichita County area. Oil was found seeping into water wells as early as 1901, and in about 1903, the same year Abilene saw its first automobile, oil was discovered just east of Wichita Falls in Clay County. Morgan Jones, quick to see the economic potential of the new Petrolia Oil Field, constructed a new branch of the Wichita Valley Railway Company northeast from Wichita Falls in 1903-1904 (Duff 1970:177; Hart 1996:952; Hendrickson 1996:956; Spence 1971:155-156).

Jones appears to have been sufficiently impressed with the agricultural-based revenues coming from the Wichita Valley Railway from Wichita Falls to Seymour during the productive years after 1896 to consider extending the line farther southwest. A line northeast of Wichita Falls into Indian Territory, though desirable because of the potential productivity of the territory, was essentially placed off-limits when the U.S. Congress failed to pass legislation necessary to open the Comanche and Kiowa reservations. In 1901, Jones made an exploratory trip through Knox County, where he visited Benjamin, Rheinland, Munday, Goree, and Eussaga. Unimpressed by the country around Benjamin, where there was "not much business in sight except cattle and no new settlers, ..." Jones described the cotton that had been ginned in Munday in 1900-1901 and the attractiveness of the soils in the part of the county south of the Brazos (sandy loam that held moisture) versus those north of the river (mesquite lands similar to those between Seymour and Dundee). He interviewed farmers about the areas where they preferred to farm, and he learned that water south of the Brazos was more readily obtainable, being as close as 16 to $30 \mathrm{ft}$ from the surface. He noted that trade from Rheinland, Munday, Goree, and Eussaga went to Stamford, though those communities were nearer to Seymour and Benjamin, because the roads were better and the Brazos River was a barrier. Building a railroad bridge would be costly, but Jones believed the Wichita Valley should cross the river 10 miles west of Seymour "and go near enough to these settlements to take all their business." Once across, it seemed inevitable that the line would go on to Abilene and intersect with the Texas \& Pacific line. There was, after all, "a fine country all the way for one hundred miles south of Seymour." Jones concluded, however, that it would not be wise to commit to any route until he and Grenville Dodge saw "what the crops will do, I mean cotton, corn, etc. ..." (Jones 1898a, 1898b, 1901).

A year later, in 1902, Morgan Jones was approached by "the Haskell folks," who lobbied him to build south and, with Stamford, Anson, and Abilene or Merkel, promised to raise 
$\$ 150,000$ to help pay for the road. Employing a combination of diplomacy and blackmail, the Haskell representatives mentioned that they had been approached by representatives of the Frisco line, but that they would rather be associated with the Wichita Valley line. However, they required an answer soon before they closed with other parties. Jones noticed that the area in question was filling up, despite a "drought" (Figure 7), largely because of the availability of underground water (Jones 1902a).

Despite the strong lobbying for an extension of the Wichita Valley line through Knox, Haskell, Jones, and Taylor Counties, Morgan Jones delayed a decision, concluding that a line into Indian Territory would be more profitable, once the country opened, and that a southern route would be dependent "almost entirely on the seasons." Approximately 3 years later, however, the citizens of Wichita Falls, Munday, and Haskell reapproached Jones with an offer of $\$ 120,000$ to subsidize construction of the Wichita Valley line from Seymour to Stamford. When "outside parties" approached Stamford about another line to that town, Grenville Dodge got wind of the possible intruder to what he considered to be Wichita Valley territory, and he sent an engineer over the potential route. He also stopped the competition by entering into negotiations and agreeing to extend the line if citizens along the future line would turn over rights of way, terminals, and subsidies totaling $\$ 63,000$. In attempting to convince the Colorado \& Southern Railroad Company-which would take over the Wichita Valley line in November 1905-of the wisdom of his plans, Dodge wrote that he had "no doubt that the extension is a good one. The country is filling up and being settled [v]ery rapidly, and will make the Wichita Valley property all right" (Dodge 1905; Jones 1902b; Leffler 1996a:501).

Two months later, on October 12, 1905, the Wichita Valley Railroad was chartered. The board of directors were Frank Trumbull of Denver; Morgan Jones of Baylor County; W. E. Kaufman and D. T. Bomar of Fort Worth; and Grenville M. Dodge, H. Walters, Benjamin F.

${ }^{1}$ The drought Jones referred to was caused by a noticeable decrease in rainfall (1901-1904). The weather subsequently turned more favorable to agriculture, which rebounded quickly (see Figure 7).
Yoakum, and Edward Hawley of New York. The corporate office was in Seymour, and Morgan Jones was in charge of construction, which began soon after and continued through much of 1906. In the meantime, Abilene, which was determined to become a "two-railroad town," became concerned that the Wichita Valley line would stop in Stamford. The city's 25,000 Club, named for its desired population, went to work and lobbied the Colorado \& Southern with the help of W. G. Swenson and Ed S. Hughes of the club, and Morgan Jones. On February 8, 1906, investors headed by Swenson received a charter for the Abilene \& Northern Railway Company, and they hired Morgan Jones to build their railroad, as well. A contract was let to Fidelity Construction Company of Wichita Falls for the 39 miles of Abilene \& Northern line from Abilene (Taylor County) to Anson and Stamford (Jones County), where it would connect with the 60 miles of Wichita Valley Railroad line from Seymour through the existing or soon-to-be towns of Bomarton (Baylor County), Goree, Munday (Knox County), Weinert, Haskell (Haskell County), and Stamford (Jones County) (Duff 1970:194; Sanders and Sanders 1986:59; Spence 1971:162-163; Werner 1996c:960).

Railroad construction, the return of good weather between 1903 and 1908, and an accompanying good showing of crops, particularly of cotton (see Figure 7), resulted in a significant increase in population, the formation of new companies, and the construction of numerous agriculture-related business in the project area. Population growth was second only to the phenomenal increases experienced following the agriculturally productive years of 1887-1890, with Wichita County population growing 177.2 percent, Archer County 160.2 percent, Baylor County by 175.6 percent, Knox County by 314.5 percent, Haskell County by 516.2 percent, Jones County by 244.5 percent, and Taylor County by 150.4 percent (see Figure 2). Certain of the favorable impact of railroad construction, D. T. Bomar, J. M. Abbott, F. C. Weinert, and B. E. Sparks formed the Wichita Valley Townsite Company for the purpose of surveying three townsites along the new line. The most ambitious of the sites was Weinert, and the company ran ads in Fort Worth and Dallas newspapers and offered free train rides to Bomarton and Weinert. The Haskell Free Press, attempting to promote that town, urged its citizens to "go to 


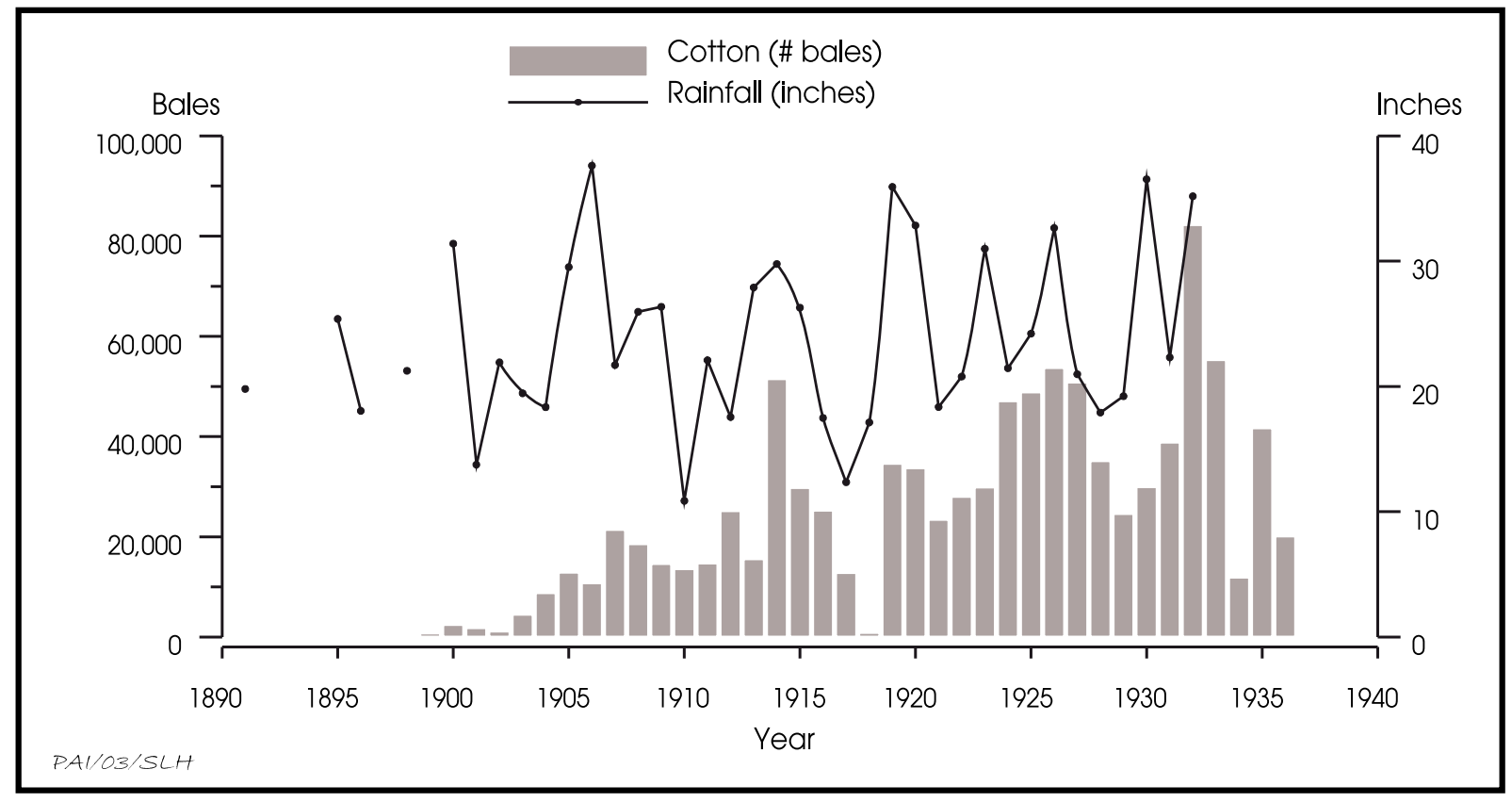

Figure 7. Rainfall and cotton production record for the Haskell County region. Data are taken from Sherrill (1975:136-137) and are typical of the context area, based on reports in county histories and primary sources, such as the Fort Worth \& Denver Railway Collection.

Weinert, meet the special train and invite the travelers to come to Haskell, 'Where they could get a good drink of water." Elsewhere along the route, new towns were platted and older towns incorporated, among them Mankins in Archer County, Mabelle and Bomarton in Baylor County, and Munday and Goree in Knox County. Seymour, in Baylor County, was able to reincorporate after the fiasco of 1890 , thanks not only to improved agricultural conditions and the broader markets that the railroad extension opened up, but also to the discovery of oil that set off another boom (Baylor County Historical Society 1972:7, 76; Davis 1996:359; Hunt 1996:983; Knox County History Society 1966:101; Lewis 1996:485; Sanders and Sanders 1986:8).

The communities along the new lines also benefited from investments by individuals and companies that built new agricultural-related facilities adjacent to the railroad. In Wichita Falls, there was a new compress and the Wichita Mill and Elevator, Texas's second largest. Seymour (Baylor County) had a new cottonseed oil company, compress and ice company, warehouses, two grain elevators (Figure 8), and livestock pens; Goree (Knox County) had a new gin and there were plans in Munday (Knox County) for a new cottonseed oil mill. Weinert (Haskell County) had two new gins, one of which was owned by the Swenson interests in Stamford. Haskell had a cottonseed oil mill, a new gin owned by Fred Sanders, and a cotton warehouse (Figure 9); while Stamford (Jones County) had a new flour mill and elevator, compress, a cottonseed oil mill and waterworks, both owned by the Swensons (Figure 10), ${ }^{2}$ and livestock shipping pens. Anson (Jones County) had a gin (Figure 11) and a mill, while Abilene (Taylor County) was the location of a new cottonseed oil company (Baylor County Historical Society 1972:7; Bomar 1907; Gray 1963:116; Hunt 1996:54; Jenkins 1996:252; Kean 1909; [Keeler] 1907; Keeler 1908, 1909b; Knox County History Committee 1966:23, 134; Sanborn Map Company 1908a, 1908b, 1908c, 1908d; Sanders and Sanders 1986:35-36; Stamford Commercial Club [1908?]:n.p.; Trumbull 1907; Wichita Falls

2 Initially, many of Stamford's agricultural businesses were adjacent to the Texas Central Railroad, which built through the town about 6 years before the Wichita Valley Railroad line was completed. 


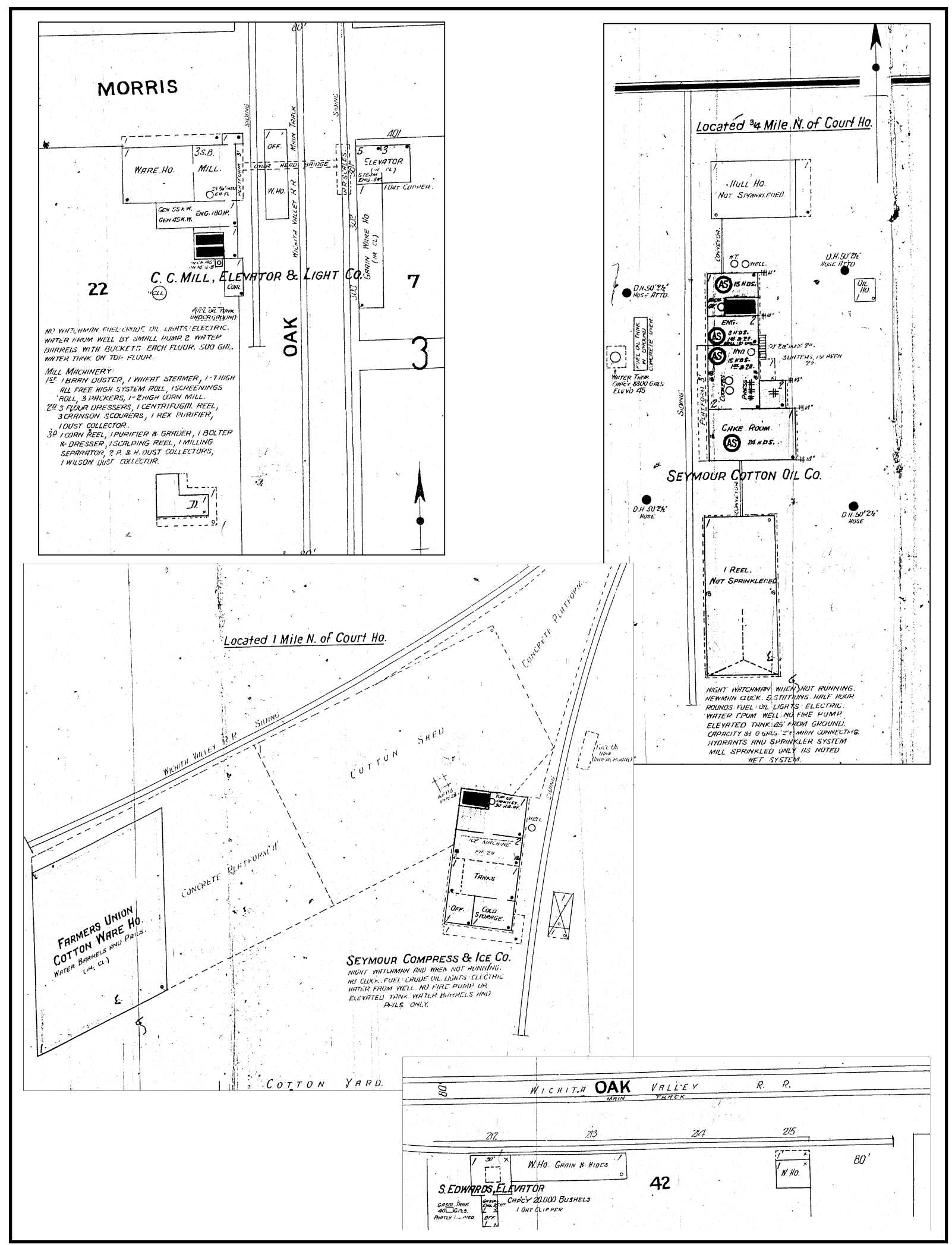

Figure 8. Sanborn maps of portions of Seymour, Baylor County, Texas, 1908. 

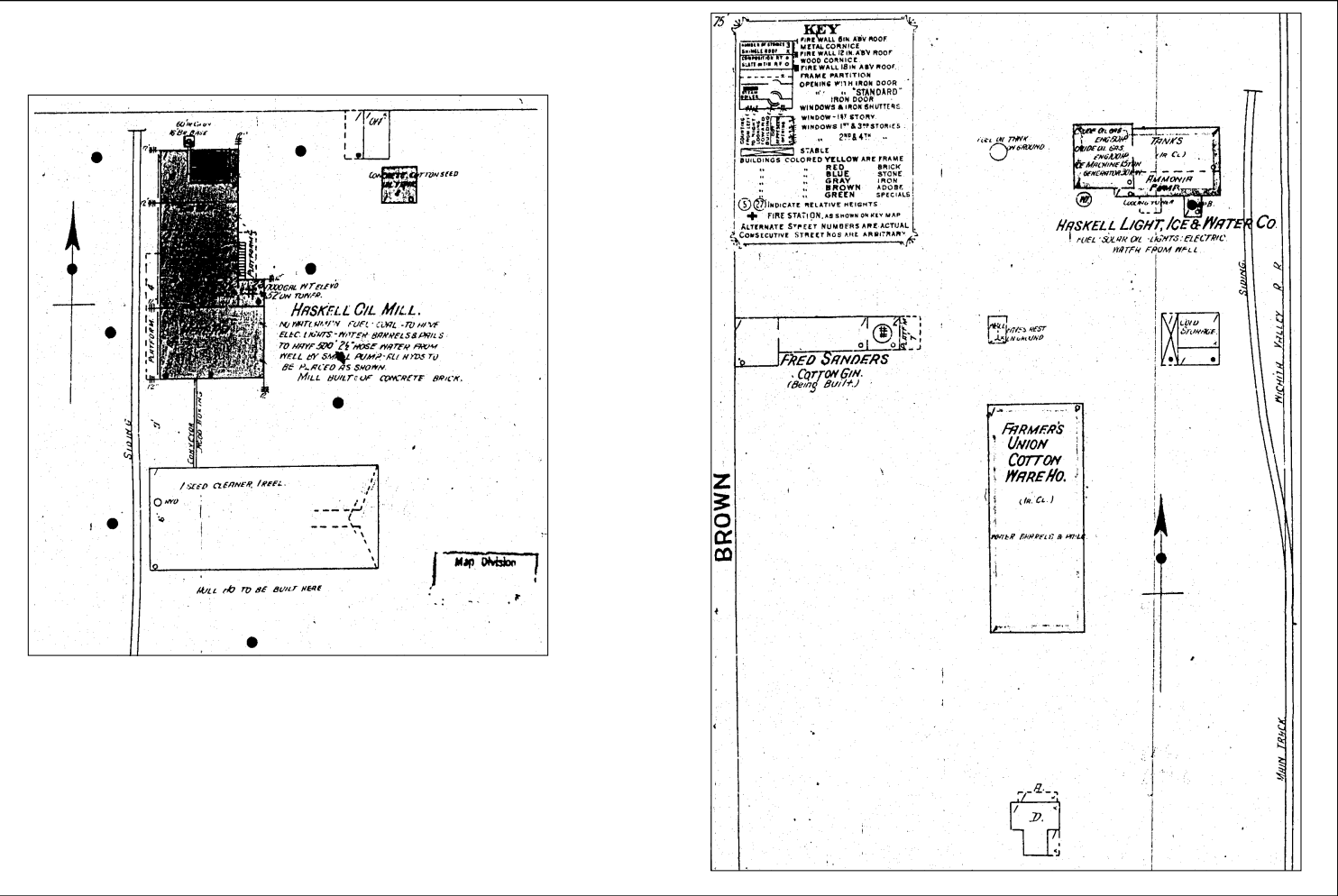

Figure 9. Sanborn maps of portions of Haskell, Haskell County, Texas, 1908.

Chamber of Commerce [1908?]:12, 14, 16).

Economic prosperity also was accompanied by the installation of infrastructure. Seymour (see Figure 8), particularly, saw numerous improvements, including a combined ice plant and cotton compress, and waterworks and sewerage system. Munday was the location of a combined water, light, and ice plant; while Haskell benefited from a light, ice, and water company (see Figure 9). Stamford (see Figure 10) had a waterworks system, electric light and power system, sewerage system, ice plant, bottling plant, and telephone connections; while Anson had power provided by the Western Light \& Power Company; and Abilene received gas service and established a street railway (Baker 1909; Baylor County Historical Society 1972:7; Downs 1996:9; Duff 1970:176; Gray 1963:116; Keeler 1908; Sanborn Map Company 1908b, 1908c, 1908d; Stamford Commercial Club [1908?]:n.p.).

Initially, relations between the Wichita Valley line officers and citizens and organizations in the project area were cooperative and mutually beneficial. The railroad board of di- rectors included residents of Wichita Falls, Seymour, Haskell, Stamford, Anson, and Abilene, and the line valued their local connections and influence. Directors and organizations, for their part, pressed the railroad to provide special privileges to specific communities, or to implement policies that would benefit the entire region. H. G. McConnell of Haskell, for example, asked Vice President D. B. Keeler in Fort Worth to promote Haskell's October-November 1907 street fair by offering passengers excursion rates from Fort Worth and all points between there and Haskell to the town, and to offer favorable rates after the fair so that people would have a chance to drive through the countryside in the general area. The secretary of Abilene's 25,000 Club suggested that Keeler inaugurate excursions of "Home Seekers" to the "Great Central West Texas Country" so that "entire train loads" could be brought through. Homer D. Wade, secretary of the Commercial Club in Stamford, made similar importunities and was rewarded with the news that the Wichita Valley line would sponsor 


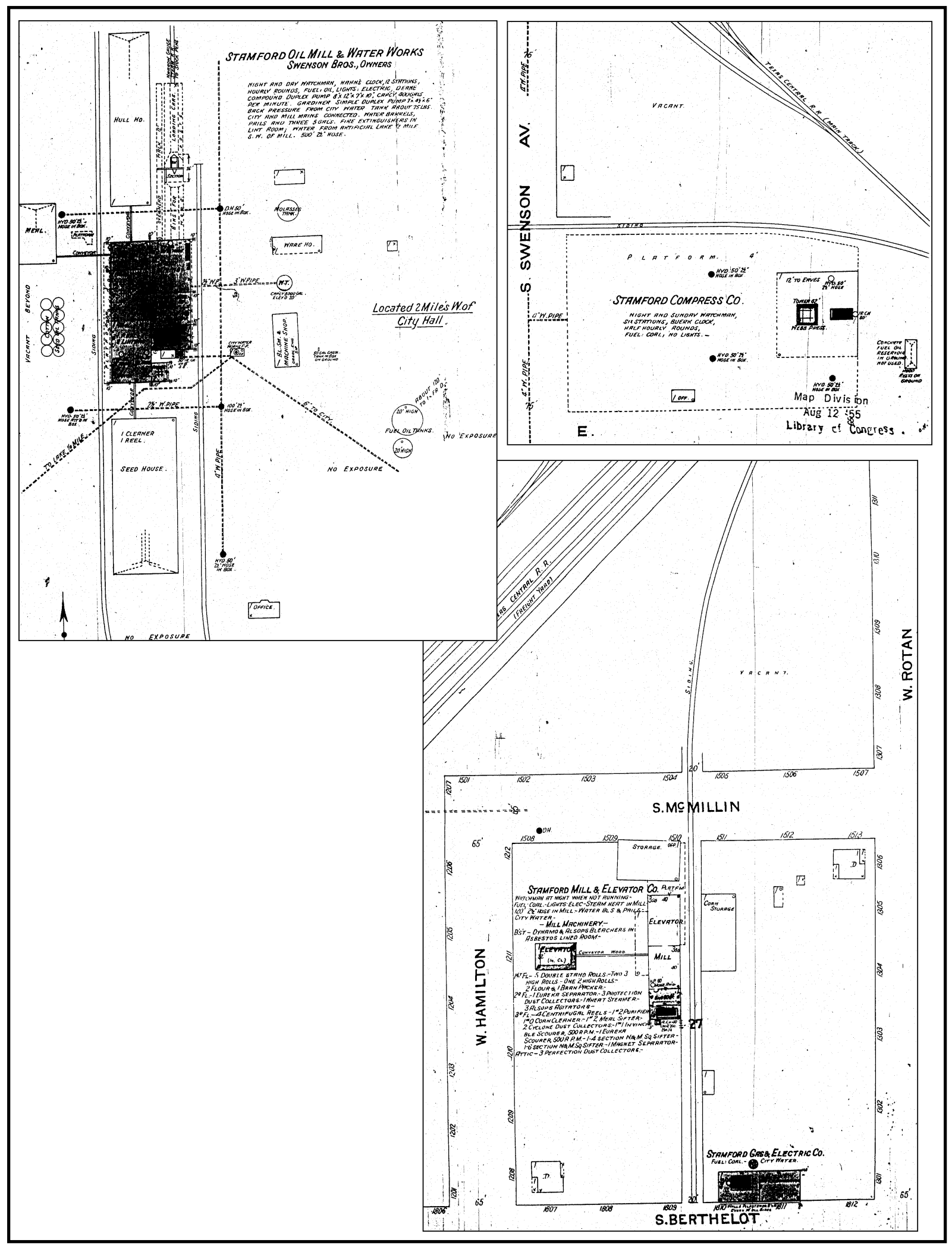

Figure 10. Sanborn maps of portions of Stamford, Jones County, Texas, 1908. 


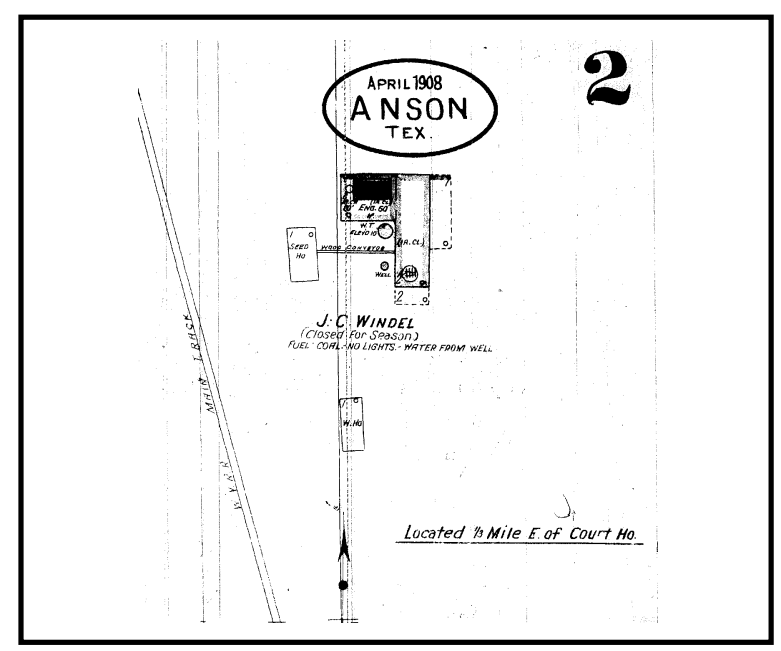

Figure 11. Sanborn map of portion of Anson, Jones County, Texas, 1908.

an excursion from Abilene to Fort Worth by way of Hawley, Anson, Stamford, Haskell, Weinert, Munday, Goree, Bomarton, Seymour, and Wichita Falls (Bomar 1907; Glisson 1908; McConnell 1907; Thomas 1907b).

Other times, however, local and regional requests were met with resistance. A committee in Haskell that made demands for a new depot at a cost of $\$ 15,000$ was characterized by a railroad official as having "an exalted idea of their needed depot facilities." And with their eyes focused primarily on the agricultural aspect of the regional economy, railroad officials rebuffed early inquiries from oil companies that were increasingly interested in the area's potential reserves. The first block of oil leases had been taken up in Archer County in 1907-1908, about the same time the manager of The Texas Company in Beaumont approached Morgan Jones, then president of the Wichita Valley Railroad Company, about the possibility of purchasing locations in Abilene, Wichita Falls, and Amarillo for refined oil distributing stations. Jones, despite his earlier interest in the Petrolia Field near Wichita Falls, responded that the railroad was not interested in selling or leasing any of its properties to the company (Cotter 1909; Dodge 1907; [Jones] 1907; O’Keefe 1969:98).

The good weather, abundant crops, and rail prosperity of 1900 to early 1908 began to fail when rainfall declined (see Figure 7), ruining a cotton crop and, later, a wheat crop (see Figure 3). The 1908-1909 cotton crop was a "great failure" in the vicinity of Munday, and conditions were particularly harsh in the Abilene area, where grain crops had suffered as well. By 1910, local businessmen were lobbying the railroad companies to provide farmers with cottonseed, which had "about run out." In the vicinity of Stamford (Jones County), there was a shortage that necessitated the hauling of water and worries that the water necessary for the Wichita Valley Railroad engines wouldn't be available (Anonymous [ca. 1909?]; Baker 1909; Hastings 1911; Keeler 1910; [Wade] 1910).

Continuation of the drought and a plague of grasshoppers further impacted both farmers and the Wichita Valley line. In the vicinity of Holliday in Archer County, residents were forced to use what small amount of water was available in the Little Wichita River and the one good well in the creek bed at the Reunion Grounds. Wheat failed or was short from Dundee in western Archer County to Seymour and Bomarton in Baylor County and Weinert and Haskell in Haskell County. Frank Hastings, Jones County manager for the Swenson interests, wrote to his employers in New York City that "the rainfall of [May 1911] has been the lowest since 1886 when only 1/3" fell" (Anonymous 1911; Hastings 1911).

The severity of the drought of ca. late 1908 to mid-1911 had significant implications for the project area. Many settlers left the region around Holliday. Homer Wade in Stamford reported that "a great many farmers, especially of the tenant class," had left the country; and for the most part, that population was not being replaced by new farmers. One railroad official reported in August 1911 that the deficits of 1909-1911 arose from "drouthy conditions." Local homeseeker tickets decreased in number and there was a decline in revenue as well from transportation to specific important occasions such as reunions, the state fair, meetings, holiday excursions, shows, carnivals, circuses, expositions, and lectures. Revenues from amusement companies and from private parties moving in equipment decreased by about 58 percent. As a result, freight revenue on the Wichita Valley lines during 5 months of 1911, alone, decreased $\$ 49,224.68$ (Glisson 1911; Keeler 1911; Lewis 1996:668; Sterley 1911; Wade 1913). 
In the northern portion of the project area, drought conditions were somewhat alleviated by the expansion of oil exploration and production, particularly in Wichita County, where The Texas Company leased oil properties on the Waggoner Ranch as early as December 1909, and the same company built a warehouse in Seymour that opened on July 1, 1910, and sold kerosene to the community. The opening of the Electra field in 1911 triggered a major shift in the economic base of Wichita County and Wichita Falls, and the impact quickly spread with the discovery of oil in Archer County the same year (Baylor County Historical Society 1972:32; Hendrickson 1996:956; Kelly 1982:32; Lewis 1996:255).

Railroad executive A. A. Glisson, himself, acknowledged that negative impacts on railroad revenues had not resulted from weather conditions alone. Declines in passenger revenues, for example, had not been entirely due to "droughty conditions." He also believed that "quite likely long distance phone service and automobile service have considerably affected our local shortdistance travel, and I suspect that this as a condition will be even stronger in the future than it has been in the past" (Glisson 1911).

The drought broke in fall 1911, but its severity had left railroadmen, local promoters, and some farmers concerned about the future of agriculture in the light of the apparently marginal character of the region. Many of them urged not only diversification but also agricultural education. W. A. Baker, who rented a Wichita Valley Railroad Company farm at Munday, suggested planting crops other than cotton, which had been such a failure recently, and his idea was reiterated by railroad official D. B. Keeler, who expressed himself "much in favor of [Baker's] diversification idea . . . both as a proposition and as an object lesson to the people around [Munday]." Later in the year, H. D. Wade of The Stamford Commercial Club suggested that the railroad company send half a dozen representative farmers from Texas on a "trip thru the North Central States [to] study the methods of farming that are in vogue there. One of our greatest troubles is in getting the farmers here to use their brains as well as their muscle in farming." Wade pointed to the efforts of Benjamin F. Yoakum, one of the original partners in the Wichita Valley Railroad, who recently had made a trip to Texas and had "decided to establish experimental farms in every county thru which his lines passed, said farms to be operated under the direction of the State Farmer's union" (W. A. Baker 1909; Keeler 1909a; Wade 1909).

Indeed, the drought had so impressed agriculturists in the area that, despite a significant improvement in weather conditions by late summer 1911, farmers and businessmen congregated in Abilene for the second annual meting of the Central West Texas Dry Farming Congress on September 27-28, 1911. Topics covered in sessions clearly expressed concerns that had developed about the region. They included "Seed Selection and Development of Drouth Resistant Varieties," "Forage [C]rops and Legumes for Dry Regions," "Dry Farming Methods and What the System is Accomplishing in Semi-Arid Countries," "Diversification and Crop Rotation in Dry Farming," "Growing Cotton in Semi-Arid Regions," "Preparation of the Soil, the Seed-Bed in Dry Farming Practice," and "Dry Land Cropping Systems for West Texas." Interestingly, the Congress was aware of the potential significance of transportation other than that provided by the railroads, and one session focused on "Good Roads, How to Build, Their Importance" (Central West Texas Dry Farming Congress 1911).

Nonetheless, the involvement of the railroads remained of paramount importance. One session was entitled "The Railroads' Interest in the Dry Farming Congress," and a second dealt with farm demonstration work. This latter topic was reiterated when the Congress adopted a resolution that recognized the pioneering work of the railroads in promoting farm demonstration work and urged them to establish a farm demonstration department that would introduce a more appropriate system of farming and comply with existing local conditions of soil, rainfall, and climate. If the Congress and railroads cooperated, their efforts would be mutually beneficial, bringing additional immigration and increased crop production and railroad tonnage (Central West Texas Dry Farming Congress 1911; Poole 1911a, 1911b).

Weather and crop conditions improved dramatically between 1912 and 1916. Gradually, the trend of emigration that had occurred prior to 1912 reversed as agriculturists became encouraged by reports of record crops. Homer Wade was able to report from Stamford in September 1912 that the cotton crop was better than that 
of 1911, and the feed crop was the best since 1906. Frank Hastings, also from Stamford, reported that rain had fallen and crops had improved by "leaps and bounds." A year-and-a-half later, Wade remarked that many of the farmers who had left a short time before were returning. There was a big demand for land, and "a feeling of confidence permeates the entire country." Other observers had some concern about the potential negative effect of war on the movement of export products, but that conflict seemed to be "the only cloud on the horizon...." Soon after, Hastings reported that Texas looked as though it would have the largest crop ever, with demand heavy for cottonseed among stock raisers and cottonseed oil in Europe. By winter 1914-1915, immense cotton crops had been gathered (see Figure 7), and spring 1915 brought wheat and oats crops that were the best in "a great many years ..." (Anonymous 1915; Hastings 1912, 1914, 1915; Keeler 1914; [Wade] 1912).

Oil production in the northern portion of the project area increased noticeably in the 19121916 period as well, with new drilling between Iowa Park and Holliday, an oil refinery constructed in Iowa Park (Wichita County), and the Panther oilfield opened 4 miles from Holliday in Archer County in 1916. No such finds were made in the rest of the project area, but their significance was not lost on residents there. Clearly understanding the ameliorating effect that oil and gas production could have on communities wracked by the highs and lows of crop and livestock production, Homer D. Wade wrote in his crop report of September 1913 that "The hope of finding oil or gas is lending considerable interest, and if we could be lucky enough to develop something along this line it would be a God-send to the entire country" (Keeler 1913; Lewis 1996:668-669; Wade 1913).

Lacking oil and gas production, observers such as Hastings and Wade fully understood the interconnectedness of beneficial weather; large crop and livestock yields; mercantile, banking, and railroad success; and construction. Frank Hastings wrote at the beginning of the recovery in 1912 that improvements in crops due to abundant rainfall had resulted in rapidly increasing bank deposits and the settling up of store accounts that had been due for 2 years. Those stores, in turn, had been able to clear themselves of obligations to eastern interests.
He predicted further increases in business. “... [P] eople who have lived on syrup and beans will probably add bacon, and the changes are that women will not have to rely on flour sacks for their underclothes. . . . [S]ome farmers['] wives will even have a new dress. ..."Two-anda-half years later, Hastings reported after the "immense cotton crop" that farmers were "buying pretty freely; not only agricultural implements, but they have been buying quite a bit of furniture and dry goods and clothing. ... I learn too that lumber is moving quite freely-better than in several years. A great many are correcting their graniaries $[s i c]$, or building sheds in which to store maize. Quite a few are putting additions on their houses, and several houses are going up" (Hastings 1912, 1915).

Indeed, thanks to oil and gas development in the northern part of the project corridor and to agricultural success along the entire line, building and the development of infrastructure were booming as well. From Goree and Munday in Knox County to Haskell, Morgan Jones, often with W. G. Swenson, purchased or established public utility companies, and at Haskell they installed "the first intercity power line ever constructed in West Texas-a 6,600-volt power line from Haskell to Rule." Wichita County residents planned to pass bonds to fund public road construction, and a concrete grain elevator with a capacity of 600,000 bushels was erected in Wichita Falls by the Wichita Mill and Elevator Company, which owned plants in Waco, Amarillo, Oklahoma City, and approximately 100 smaller towns. Seymour experienced significant changes, getting electric streetlights. By 1916, the Seymour Cotton Oil Company had expanded with the additions of oil tanks, a larger seed house, and other improvements. A number of older companies were still in business, including the Seymour Mill, Elevator, and Light Company. New companies and improvements included Fuller Grain Company, Pierce-Fordyce Oil Association, Magnolia Petroleum Company, The Texas Company, W. B. Bowman Lumber Company, a freight house, and a wagon yard (Figure 12). J. D. Avis's 1913 compress, which had burned in 1915, had been replaced by a factory run by Guitar Industries of Abilene. Baylor County voters as a whole approved the first of a series of bonds to construct roads (Baylor County Historical Society 1972:7-8; Belo \& Company 1912:365; Kelly 1982:87; Sanborn 


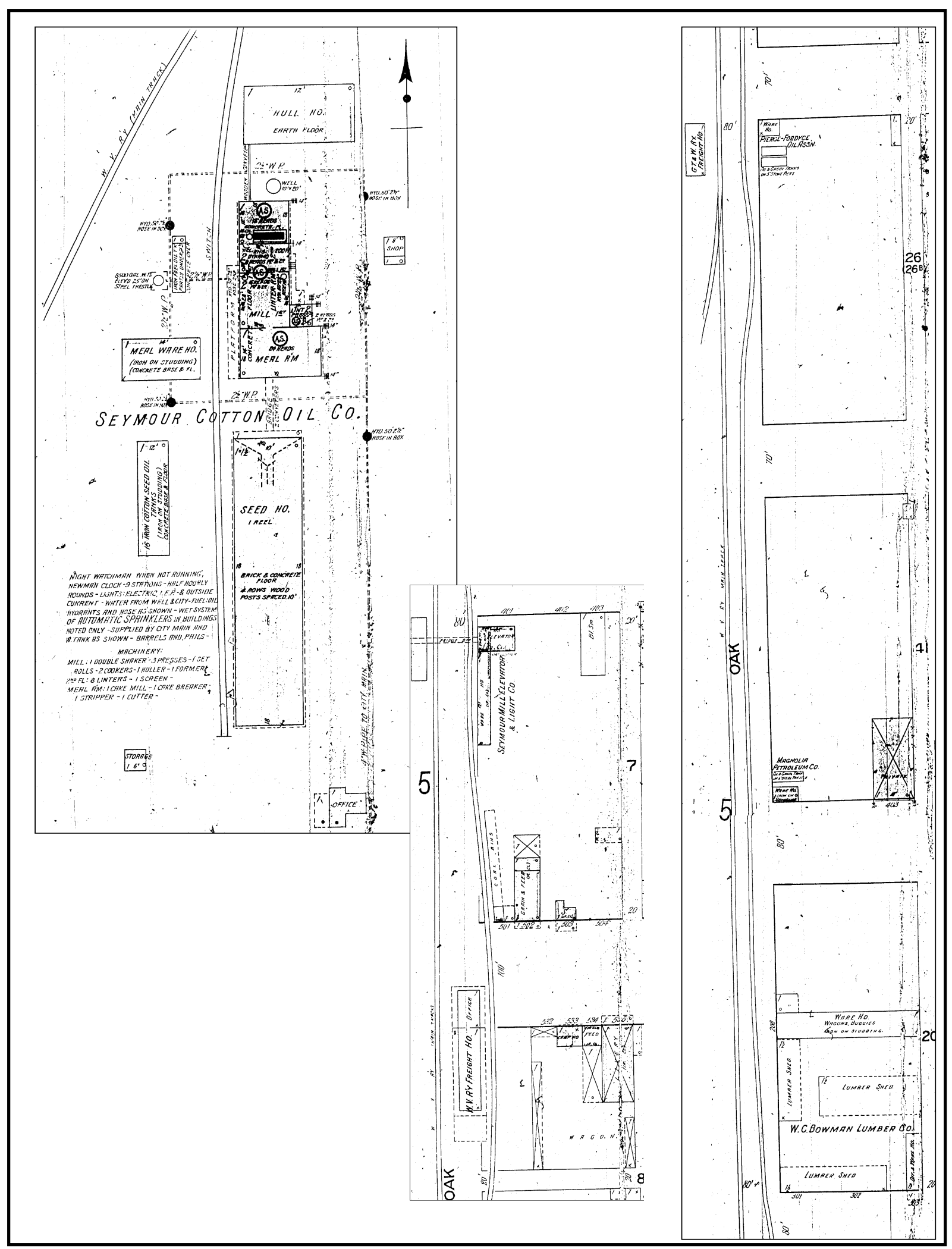

Figure 12. Sanborn maps of portions of Seymour, Baylor County, Texas, 1916. 
Map Company 1916; Spence 1971:206).

Down the road in Munday (Knox County), 26 men organized in 1914 to form the Farmers' Cooperative Gin, which eventually became the second-oldest Farmers' Union gin in Texas and symbol of the Farmers' Union gin association movement of 1905 . In the next town south along the Wichita Valley line, another group of farms organized and built the Union Gin in Weinert (Haskell County) just east of the railroad. Haskell, the county seat, was approached by an investor interested in building a new rail line at right angles to the Wichita Valley line, and the Western Cotton Oil \& Gin Company, which had expanded the earlier Haskell Oil Mill operation, expressed interest in expanding their real estate holdings near the railroad to accommodate a larger feed lot operation. Fred T. Sanders and Newsom \& Son had begun operations of cotton gins, while R. E. Sherrill had built a grain elevator (Figure 13) (Cogdell 1912; Keeler 1912; Sanborn Map Company 1913a; Sanders and Sanders 1986:36; White 1957:117, 120-121).

Observers in Stamford (Jones County) remarked on the amount of building going on in that town. According to Frank Hastings, lumber was moving freely. Homer D. Wade wrote to the Swensons in September 1915: "There are more people hunting land, renters and buyers, than any time within the past six years, and as stated in a previous letter, there is more building going on in the town of Stamford, than any time within the past five or six years. I think the same conditions prevail in other towns." Due to continuing competition from the Texas Central Railroad, construction near the Wichita Valley line was relatively modest, consisting of a produce company facility, railroad freight house, and meat-packing plant owned by Armour \& Company (Figure 14). Improvements in Anson (Figure 15) were limited to the Pipes \& Son Gin (see Figure 15), although other gins had been constructed elsewhere in town. Abilene saw the consolidation of its streetcar, gas, electric, water, and ice companies under the ownership of eastern business giant, American Public Service Company. About the same time, Taylor County residents voted for road bonds to support further improvements to the existing 55 miles of surfaced highway (Belo \& Company 1912:355; Duff 1970:177; Hastings 1915; Sanborn Map Company 1913b, 1914; [Wade] 1915; Wade 1914).
The years of prosperity from ca. 1912 to mid1916 left residents in the project area unprepared for one of the worst droughts in West Texas history (see Figure 7). Almost no rain fell from mid-1916 to 1918 , and conditions reached a crisis stage. The Wichita Valley Railway was cut off from water entirely at Stamford and had to haul daily from Abilene. Few crops were made in the seven-county region and beyond, and so many farms failed that the effects were felt as late as 1920, when the census recorded population losses in six of the seven counties: Archer lost 19.5 percent of its population, Baylor 16.5 percent, Knox 4.0 percent, Haskell 12.7 percent, Jones 8.1 percent, and Taylor 8.4 percent. Of the seven, only Wichita County gained (453.0 percent), due entirely to the phenomenal strength of the oil and gas industry. Discovery of the Burkburnett oil fields in 1918 during the worst of the drought fueled a boom in Wichita Falls, which grew from ca. 17,000 in July 1918 to more than 40,000 in 1920. The Texas Company became the county's largest taxpayer in 1918, the same year thousands of families left their failing farms to find work in the oil fields of Wichita County and in the area of Abilene, which was experiencing the beginnings of oil development (Duff 1970:211; Gausewitz 1917; Parfet 1956:52).

The record drought was followed immediately by an extraordinarily favorable year in 1919 (see Figure 7) that not only produced tremendous wheat and cotton crops $^{3}$ (see Figures $4,5,7)$ but also inaugurated an almost decadelong period of growth. Supported by generally favorable weather, by the expansion and growth of the oil and gas industry south from Wichita County and north from Taylor County, and by the construction of municipal and regional water storage facilities to prevent a recurrence of the recent water shortages, the project area prospered. County-wide population grew in all seven counties between 1920 and 1930, especially in Taylor and Archer Counties (see Figure

\footnotetext{
${ }^{3}$ Baylor County farmers in the northern part of the project area harvested more grain per acre in 1919 than at any time in the past, even during the 1914 season that produced record crops across the entire western United States. Similarly, Taylor County farmers had record-breaking cotton crops (Baylor County Historical Society 1972:8-9; Zachry 1980:59).
} 

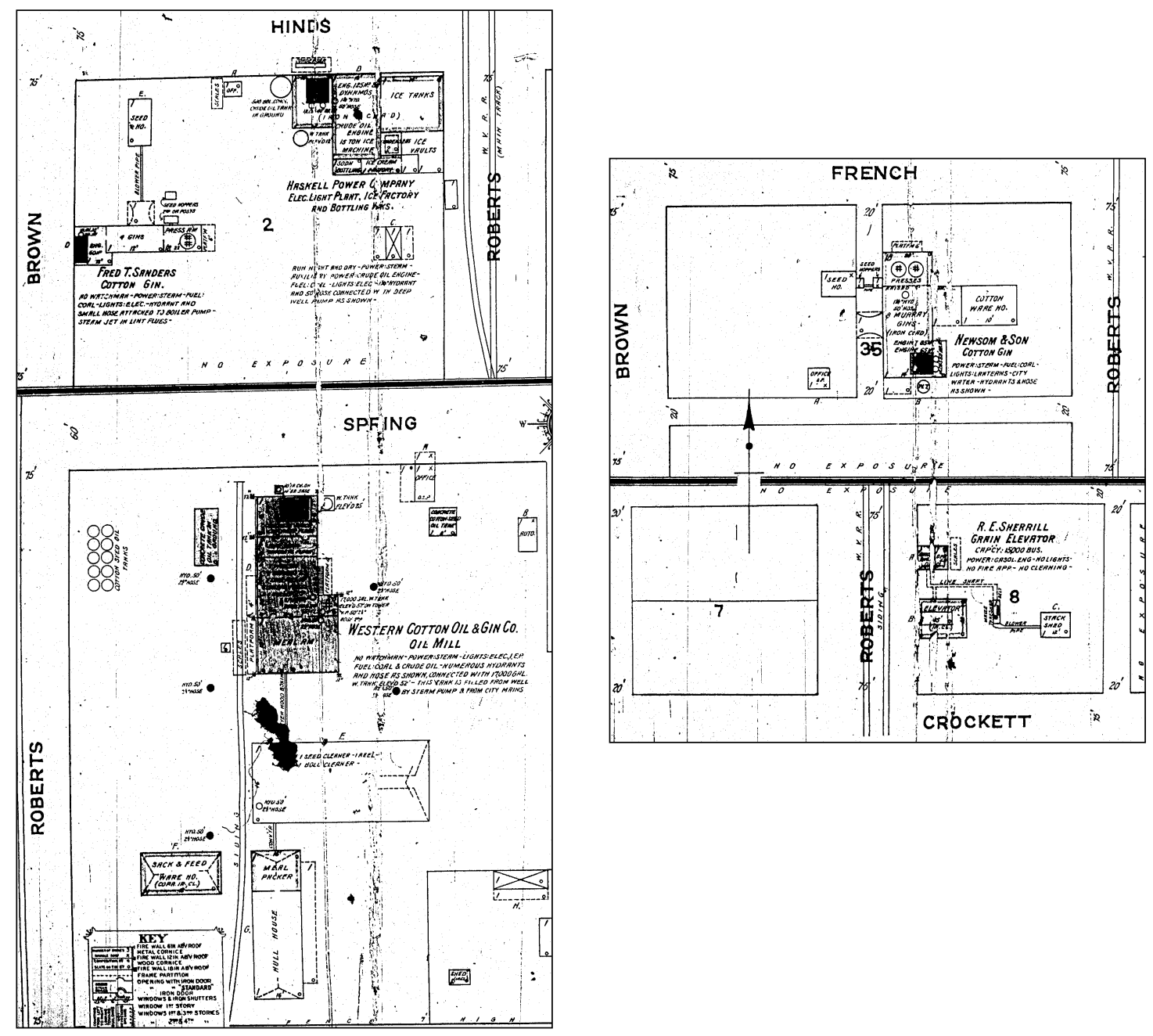

Figure 13. Sanborn maps of portions of Haskell, Haskell County, Texas, 1913.

3 , while population growth in towns between 1920 and 1925 was significant as well, Wichita Falls increasing by 46 percent, Munday by 81 percent, Goree by 30 percent, Haskell by 52 percent, Stamford by 75 percent, Anson by 111 percent, and Abilene by 27 percent (A. H. Belo \& Company 1926:209, 212, 251, 255, 280, 303, 317).

General prosperity was fueled in the early 1920s by the discovery and development of oil and gas fields in Wichita County, which represented about 21 percent of total state production in 1921; by discovery of 47 pools in Archer County in $1922-1926 ;^{4}$ and by discovery of oil deposits in Baylor County in 1924 that were sufficiently large to help diversify the local economy. Discoveries in the southernmost counties occurred later, the first in 1926 when Phillips Petroleum Company struck oil southwest of Anson at Noodle Creek. Haskell County's first oil wells were drilled and spudded in 1929 , the same year major oil discoveries were made in Taylor County (Graves 1996:427; Leffler 1996a:501, 1996b:224; Loftin 1979:170; Odintz 1996:995; Ricci 1996:193).

${ }^{4}$ In 1925-1926, Archer County ranked third in the state in production. A total of 51 pools was discovered in Archer between 1911 and 1926; 93 percent of them were discovered in 1922-1926 (Loftin 1979:170). 


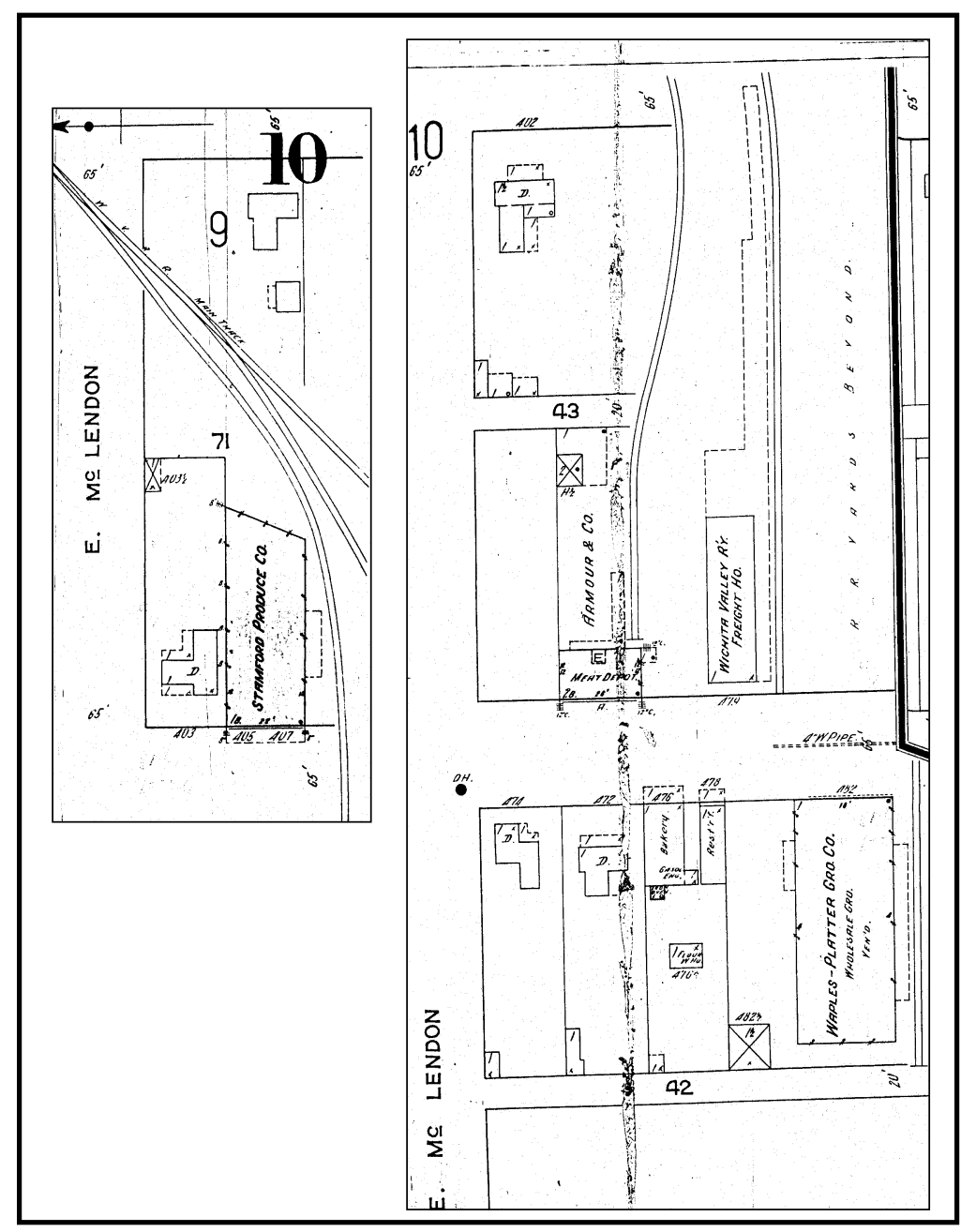

Figure 14. Sanborn maps of portions of Stamford, Jones County, Texas, 1913.

Agricultural-based prosperity increased as well as agriculturists remained buoyed by the record harvests of 1919. Between 1919 and 1924 , the number of farms grew in all seven counties, the greatest increases occurring in Baylor (19 percent), Knox (49 percent), Haskell (27 percent), and Taylor (43 percent) Counties (Figure 16). The amount of land in farms increased, most notably in Baylor (27 percent) and Knox (120 percent) Counties. Throughout the region, wheat (which decreased in all counties between 1919 and 1924 and again between 1924 and 1929) [see Figure 4] took a back seat to cotton, whose production burgeoned in six of the seven counties ${ }^{5}$ between 1919 and 1924 . Cotton production then decreased by an average of
49 percent by 1929 , even though farmers in all counties planted an average of 17 percent more land in the crop in 1929 than they had in 1924 (see Figure 5). Such statistics demonstrate a persistent dedication to the crop despite the devastation wrought by the boll weevil, which was moving toward the High Plains area.

The region's prosperity was reflected in what one author called a "building spree" that was expressed in agriculturalrelated buildings and in town and country infrastructure. Dundee, for example, benefited during the 1920s from the construction of Lake Kemp, Lake Diversion, and an irrigation ditch that provided ready sources of water for agriculture. Seymour citizens built a hospital in 1923 and a city hall and hotel in 1924. Property adjacent to the Wichita Valley line also continued to develop: in 1925 , lots were the locations of improvements owned by Pierce Petroleum, Magnolia Petroleum, Texhoma Oil, Gulf Refining, and The Texas Companies; Seymour Mill \& Grain, Graham Mill \& Elevator, and Stallings Grain \& Coal Companies; Seymour Cotton Oil and Seymour Compress Companies; Musser Lumber Company; and the Texas Public Utilities Company, which ran an ice plant on its site (Figures $17,18)$. The following year, a farmers' cooperative constructed a gin in the town, adhering to a trend that developed in Texas between 1921 and 1930 when many of the cooperative organizations were formed. On a county-wide basis, Baylor County citizens approved bonds to build roads (Baylor County Historical Society 1972:8, 37; Loftin 1979:238; Sanborn Map

${ }^{5}$ Archer County, whose production fell slightly between 1919 and 1924, actually increased its acres devoted to cotton production by 77 percent. 
Company 1925b; White 1957:121).

In adjacent Knox County, citizens in Goree voted bonds to sink a city well and pipe water to homes in the town, and Sanborn Map Company maps recorded healthy development along the Wichita Valley tracks in Munday (Figure 19). Unlike Seymour, which was more proximate to the Wichita and Archer County oil fields and had a greater number of oil- and gas-related properties as a result, Munday's improvements were almost exclusively agriculture related. Adjacent to or near the Wichita Valley line, they included the Munday Gin, People's Gin, Farmers Union Gins, and McElreath \& Frost Cotton Gin; the Munday Cotton Oil Company; ${ }^{6}$ Farmers Elevator Company and Munday Mill \& Elevator Company; and the West Texas Utilities Company, an entity organized in Abilene in 1923 that quickly acquired local utility companies in four of the seven counties by 1927 (Downs 1996:1:9; Knox County History Committee 1966:167; Sanborn Map Company 1925a; West Texas Utilities Company 1927:24-25).

Weinert in Haskell County got a movie house, the Rex Theater, in 1921, while agricultural improvements included a gin built by Bill Donnigan and George Williamson in 1923 and purchased by Will Stith of Abilene and Ernest Griffith of Weinert in 1928. The owner of the Newsom Gin added new machinery in 1924 and replaced the entire complex with a new building and new machinery in 1928, the same year a group of farmers organized a new co-op gin. To the south, Haskell's industries along or near the Wichita Valley line included the Fred T. Sanders Cotton Gin, Irby \& Vose Cotton Gin, Haskell Electric Gin Company, Farmers Gin Company, the expanded Western Cotton Oil \& Gin Company Cotton Oil Mill, the expanded R. E. Sherrill Grain Warehouses and Elevator, and the Haskell Light \& Ice Company (Figure 20). In Jones County, Stamford's improvements consisted of a Wichita Valley Railroad round house, while Anson's improvements were weighted to the cotton industry as evidenced

\footnotetext{
${ }^{6}$ The Munday Cotton Oil Company, which built its facility in 1921, was on the former site of the Swenson Gin. The Swenson Gin burned in 1917 and never was rebuilt (Sanders and Sanders 1986:35), probably because of the disastrous weather and small crops of 1917-1918.
}

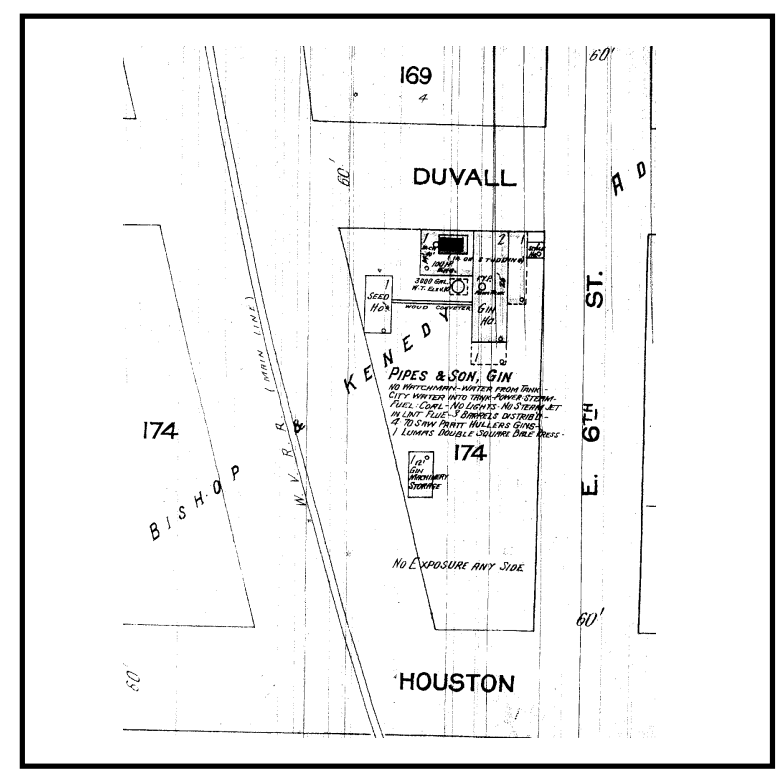

Figure 15. Sanborn map of portion of Anson, Jones County, Texas, 1914.

by two gins adjacent to the rail lines (CranstonWilliamson and Pipes \& Son) (Figure 21). Finally, in Taylor County, the number of cotton gins in Abilene increased markedly beginning in 1926, with acres planted in the crop breaking all past and future records (Sanborn Map Company 1921, 1922; Sanders and Sanders 1986:11, 36-37; Zachry 1980:62).

The late 1920s represented something of a nadir for most of the counties in the project area, insofar as population was concerned. Thereafter, Archer, Baylor, ${ }^{7}$ Knox, Haskell, and Jones Counties lost population at an average rate of 8.0 percent during the $1930 \mathrm{~s}, 6.0$ percent during the $1940 \mathrm{~s}$ (when an influx of military populations may have slowed the rate of decline), and 15.6 percent during the $1950 \mathrm{~s}$, statistical trends that may have contributed to cessation of passenger service on the Wichita Valley line in 1949 (Kelly 1982:21). In contrast, during the same 30-year period, populations in Taylor County increased by 8 percent (1930s), 44 percent (1940s), and 60 percent (1950s), while the population of Wichita County, which decreased by 1 percent during the 1930 s, increased by 34

\footnotetext{
${ }^{7}$ Baylor County's population actually grew by 5 percent during the 1930 s but declined thereafter.
} 


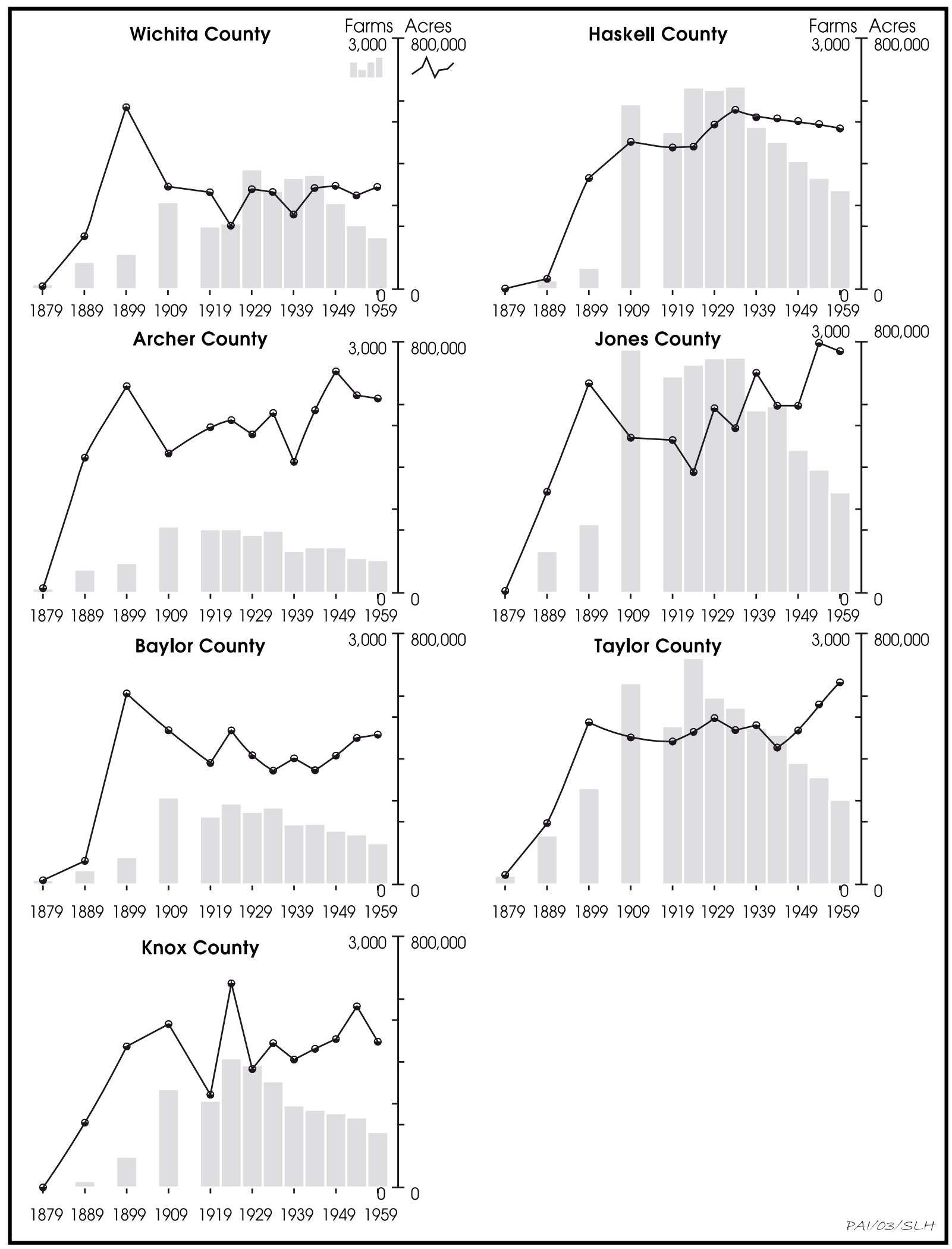

Figure 16. Numbers of farms and acres in farms in the project area, 1880-1960. 


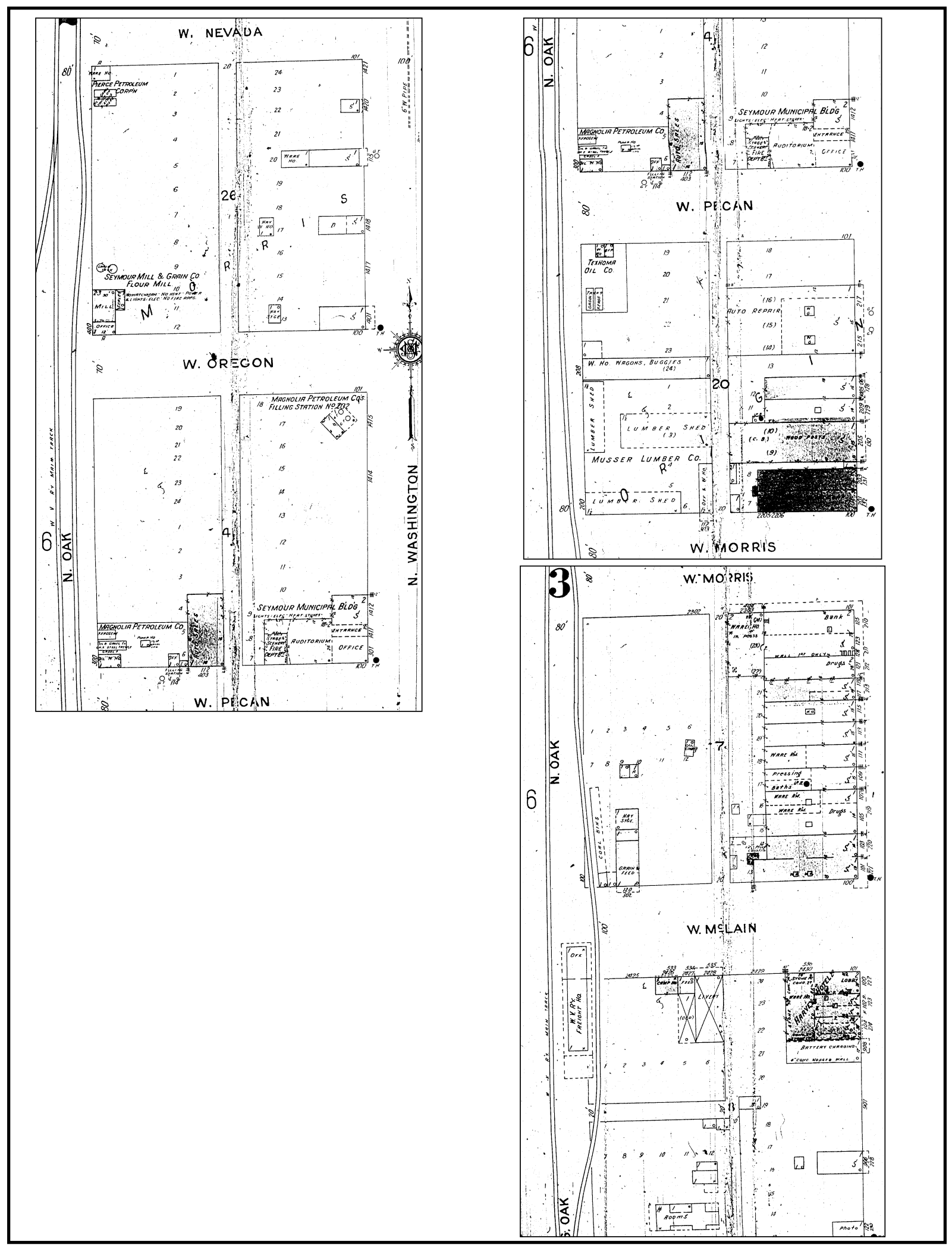

Figure 17. Sanborn maps of portions of Seymour, Baylor County, Texas, 1925. 


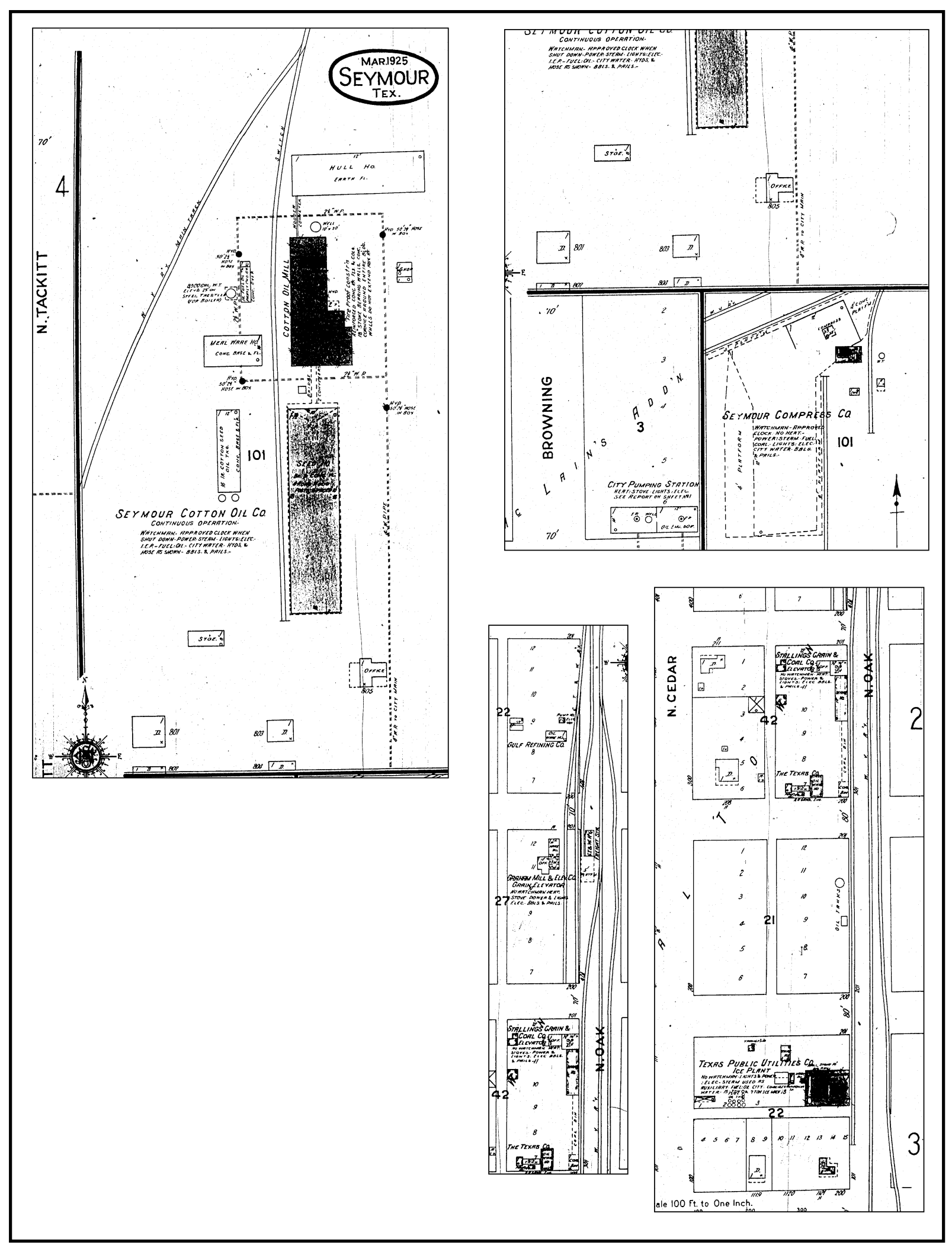

Figure 18. Sanborn maps of portions of Seymour, Baylor County, Texas, 1925. 


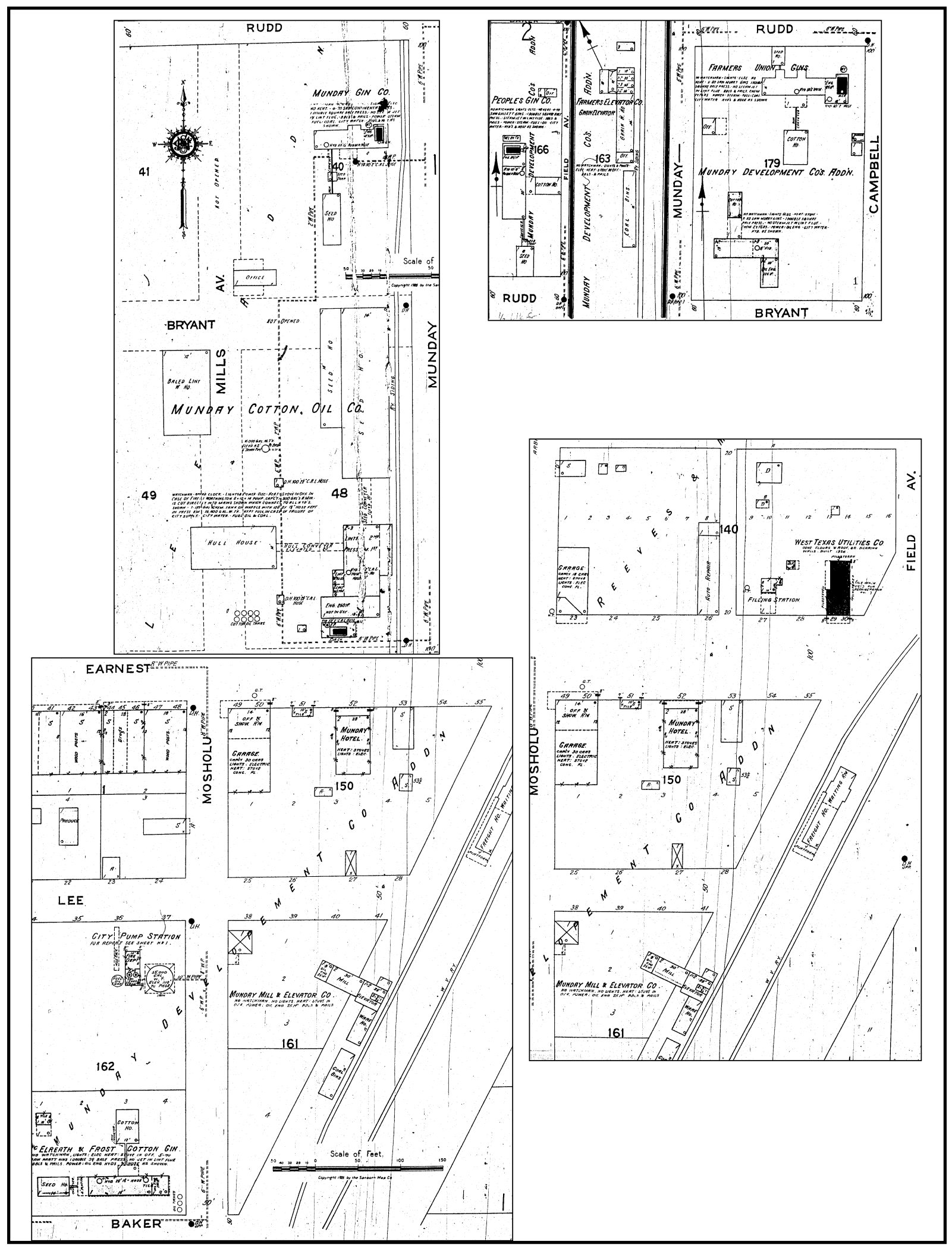

Figure 19. Sanborn maps of portions of Munday, Knox County, Texas, 1925. 

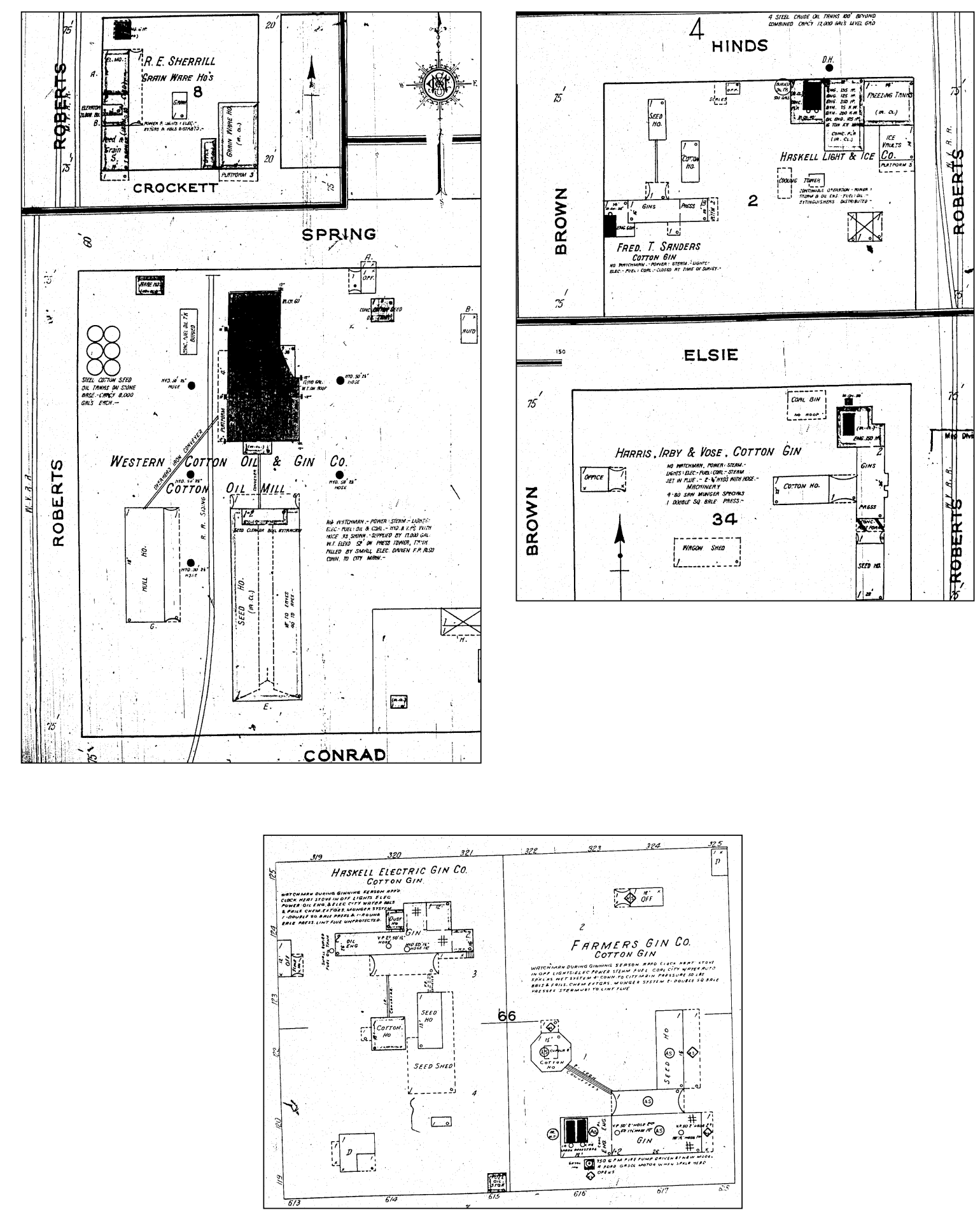

Figure 20. Sanborn maps of portions of Haskell, Haskell County, Texas, 1921. The Harris, Irby \& Vose Cotton Gin is erroneously identified as being in block 34 . Its actual location was on block 36 . 
percent in the 1940s and 25 percent in the 1950 s (see Figure 3).

Cotton production during the same period was relatively stagnant between 1929 and 1939 and then steadily increased in some counties to levels in 1949 that were beyond even the highs that typified the 1920s (see Figure 5). However, there appears to have been little correlation between bales produced and acres cultivated between 1929 and 1944. Acres cultivated precipitously declined in most counties between 1929 and 1944, probably due to the requirements of the Agricultural Adjustment Act of 1933 and successor acts that placed quotas on production and later rewarded withdrawal of acreage in 1950. But bales harvested remained constant between 1929 and 1939 and then increased disproportionately to the acreage cultivated after that date, perhaps because of the introduction during the 1940s of mechanized machinery (Tyler 1996a:56-57).

Wheat production between 1924 and 1939 lagged far behind the record harvest of 1919, although the 1934 harvest was modestly larger than that of 1929 (see Figure 4). The harvests of 1944-1959 were notably greater, however, clearly outstripping even the 1919 amounts except in Wichita and Archer Counties. Unlike cotton acreage versus bales gathered, patterns in wheat acreage usually mirrored patterns in bushels harvested.

While significant outside factors such as depression, drought, a world war, and government policies impacted the economy after 1930, the region's reliance on agriculture was remarkably persistent and displayed itself in the communities between Wichita Falls and Abilene. Between 1930 and 1950, for example, Seymour, Munday, Haskell, Stamford, and Anson all grew even though Baylor, Knox, Haskell, and Jones Counties lost population. The strength of these communities and persistence of agricultural traditions, despite irregular and often smaller crop yields, were expressed in the continued operation of commercial properties associated with processing. For example, Seymour's five grain- and cotton-related companies near the Wichita Valley line in 1930 (Figure 22) were still in existence in 1940 (Figures 23, 24) despite a 56 percent decrease in cotton harvested between 1929 and 1934, followed by a 69 percent increase between 1934 and 1939 that still left an overall decrease of 26 percent in Baylor
County for the decade. Munday (Knox County), which had seven grain- and cotton-processing plants in 1925 (see Figure 19), had eight such properties in 1942 (Figures 25, 26) and had seen its population grow by 47 percent when the census was taken in 1950. Haskell, which had six cotton- and grain-related properties adjacent to the railroad in 1931 (Figure 27) had 10 such companies in 1941 (Figure 28). It had seen its population grow by 18 percent in the 1930 s, and it grew another 26 percent in the 1940s (Hunt 1996:886; Sanborn Map Company 1930, 1931, 1940, 1941, 1942). Stamford, in Jones County, gained population during the 1930s and grew again by 21 percent in the 1940s. However, development of agriculture-related properties adjacent to the Wichita Valley line remained stagnant, although they appear to have flourished near the other two railroads. By 1939, Anson had actually lost one of the two cotton gins that had been adjacent to the tracks in 1930 (Figures 29, 30), making it the only town in the project area for which Sanborn maps exist that showed a loss of such a property prior to World War II.

Oil production, such as that from the Lasson field near Haskell, continued to be a mitigating factor for local economies after 1950, as did the presence of large military installations in Wichita Falls and Abilene. In addition, agriculturists turned increasingly to livestock production, particularly after the devastating

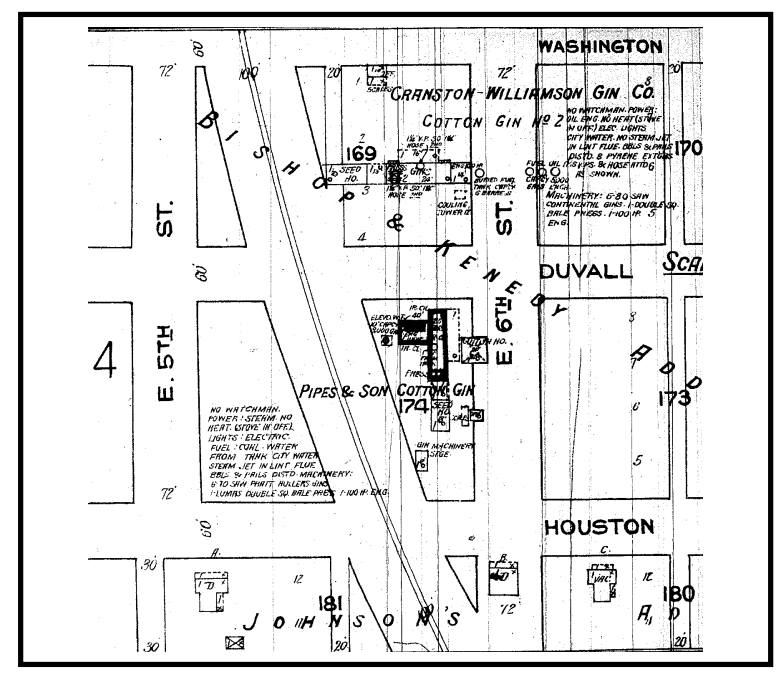

Figure 21. Sanborn map of portions of Anson, Jones County, Texas, 1922. 


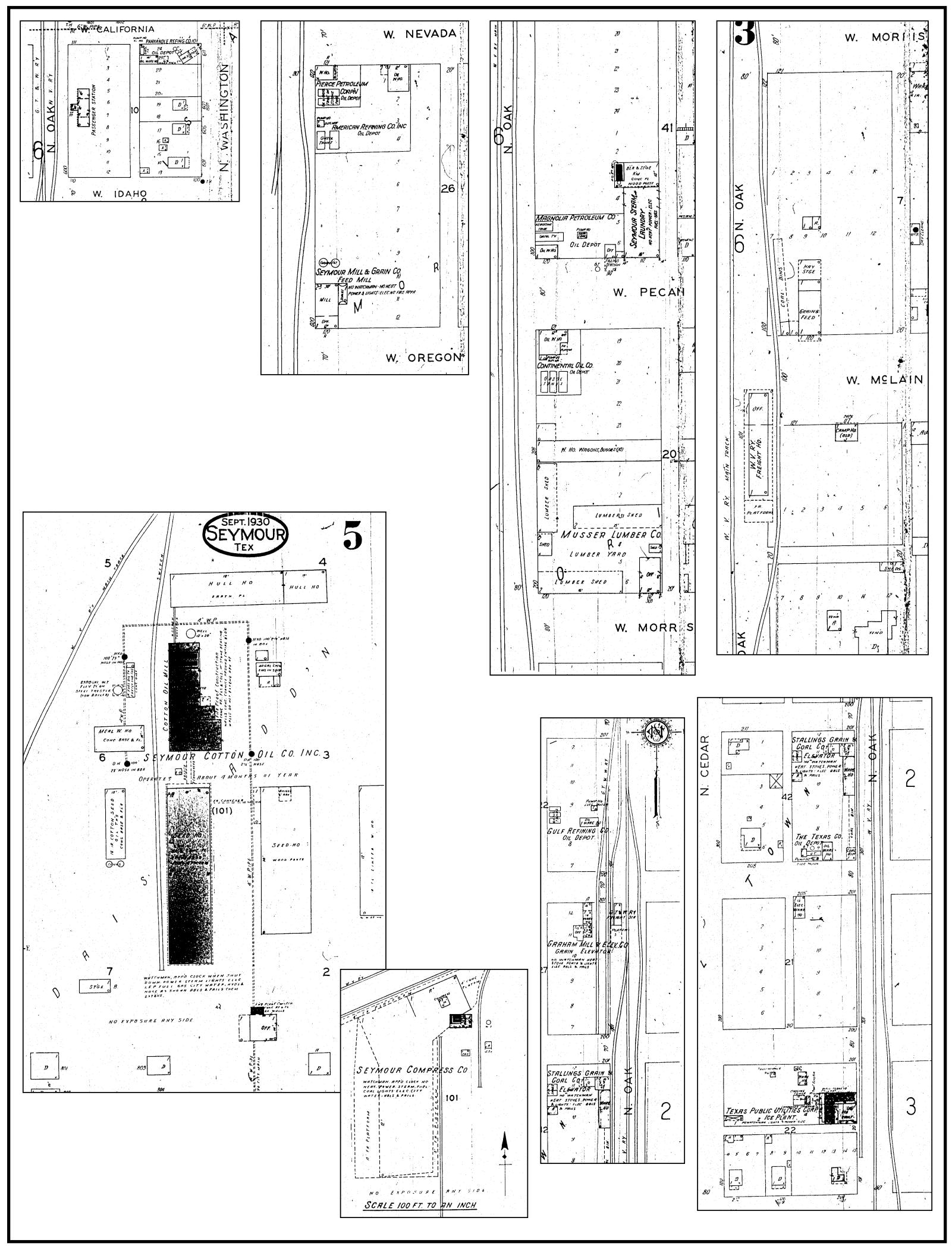

Figure 22. Sanborn maps of portions of Seymour, Baylor County, Texas, 1930. 

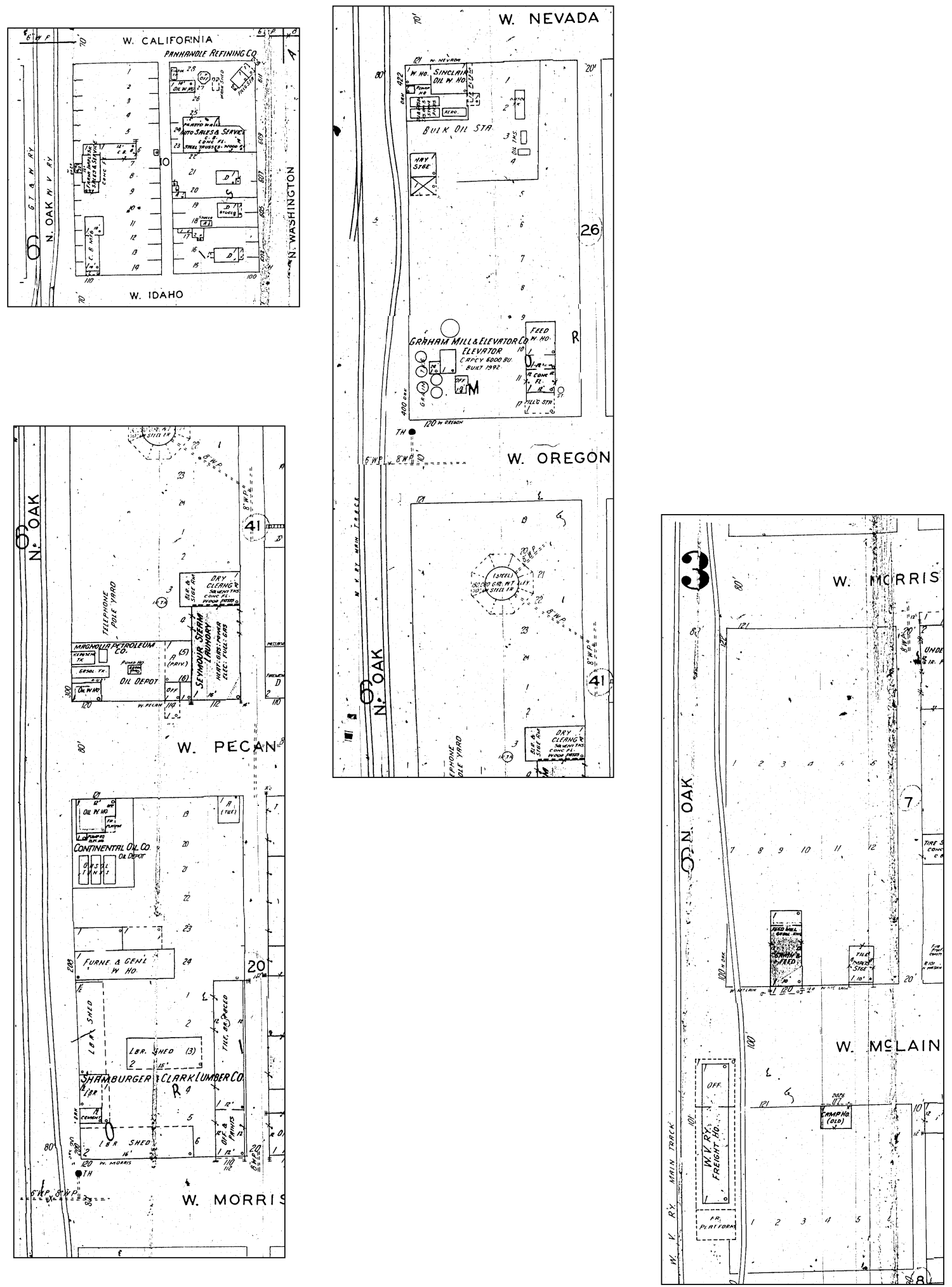

Figure 23. Sanborn maps of portions of Seymour, Baylor County, Texas, 1940. 


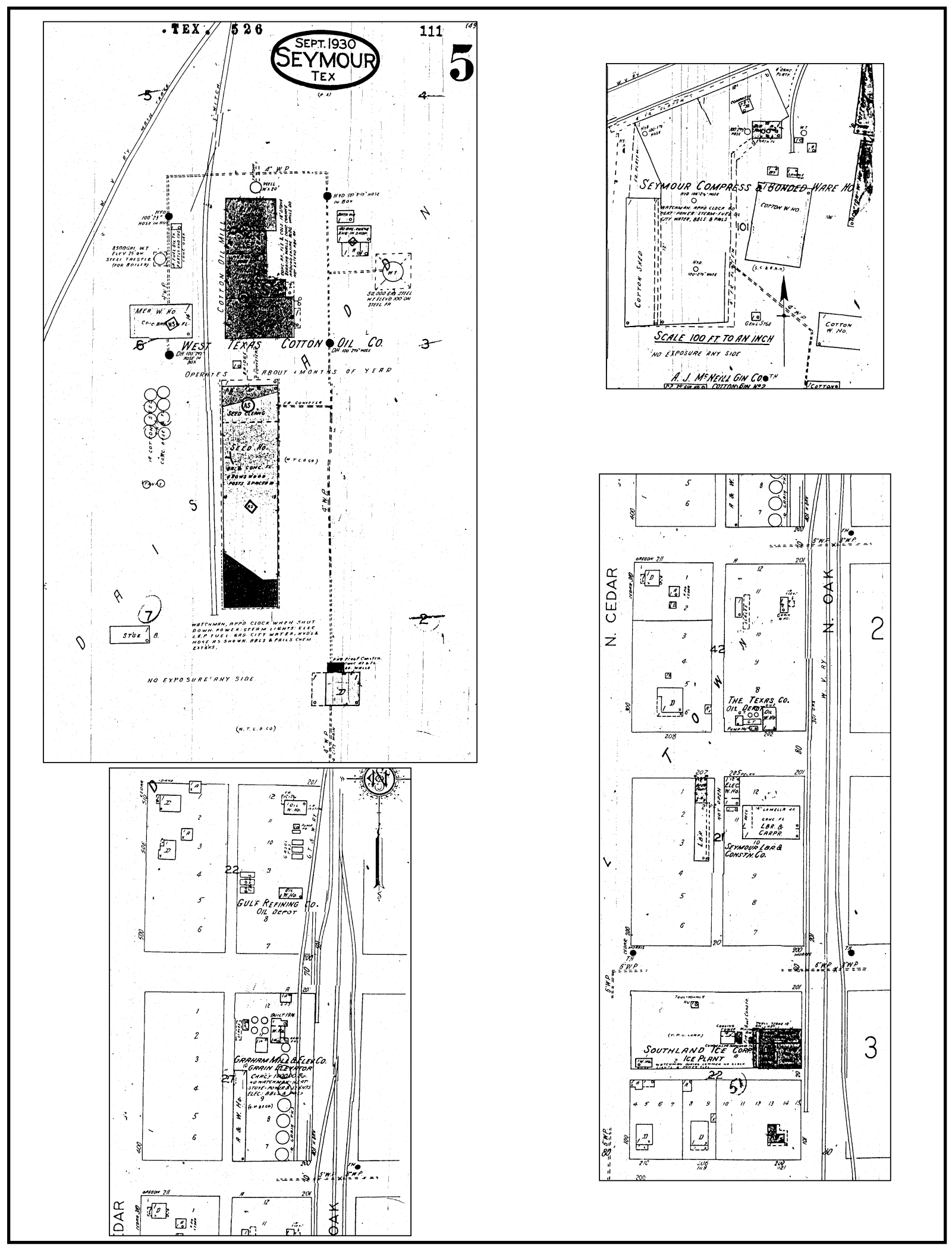

Figure 24. Sanborn maps of portions of Seymour, Baylor County, Texas, 1940. 


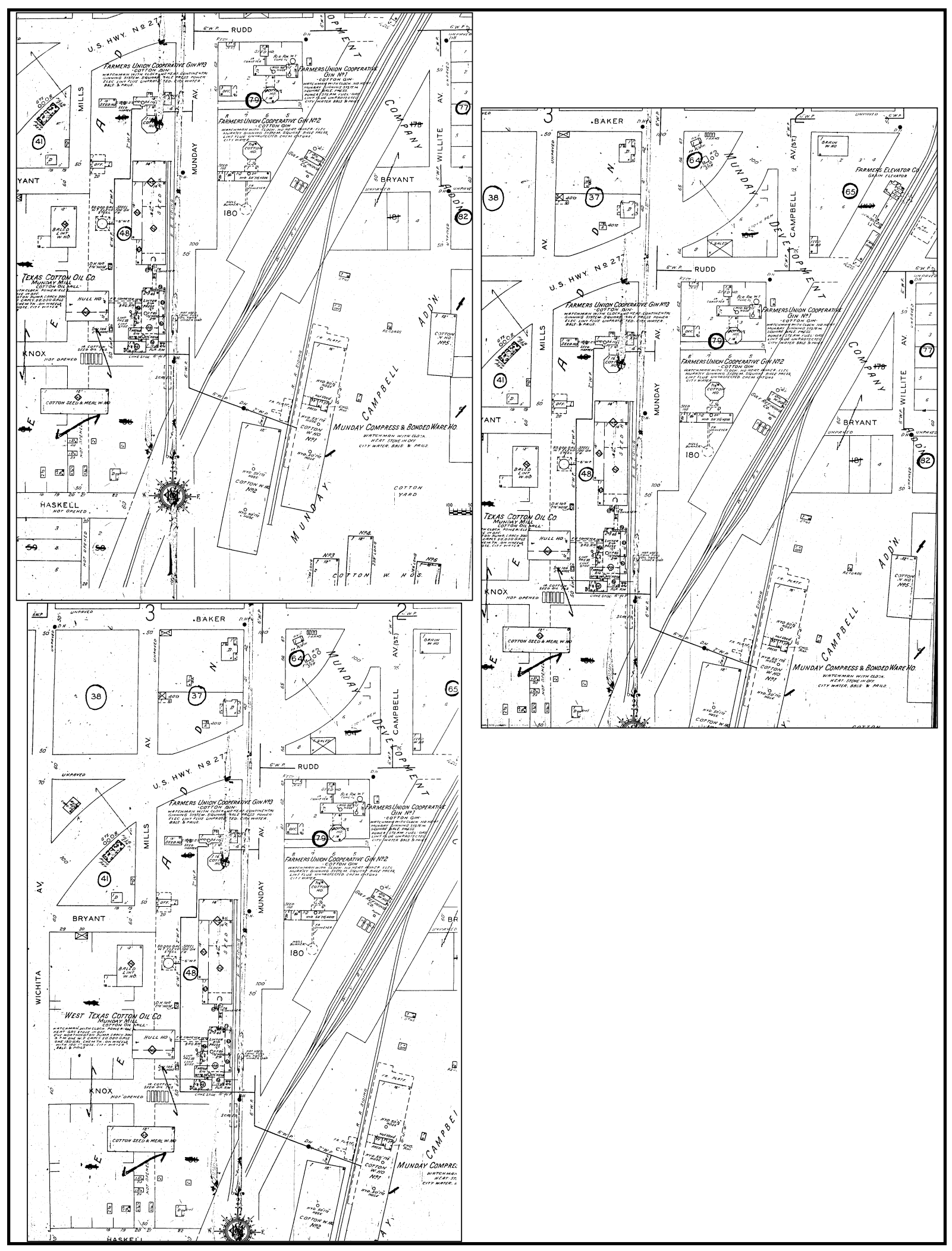

Figure 25. Sanborn maps of portions of Munday, Knox County, Texas, 1942. 

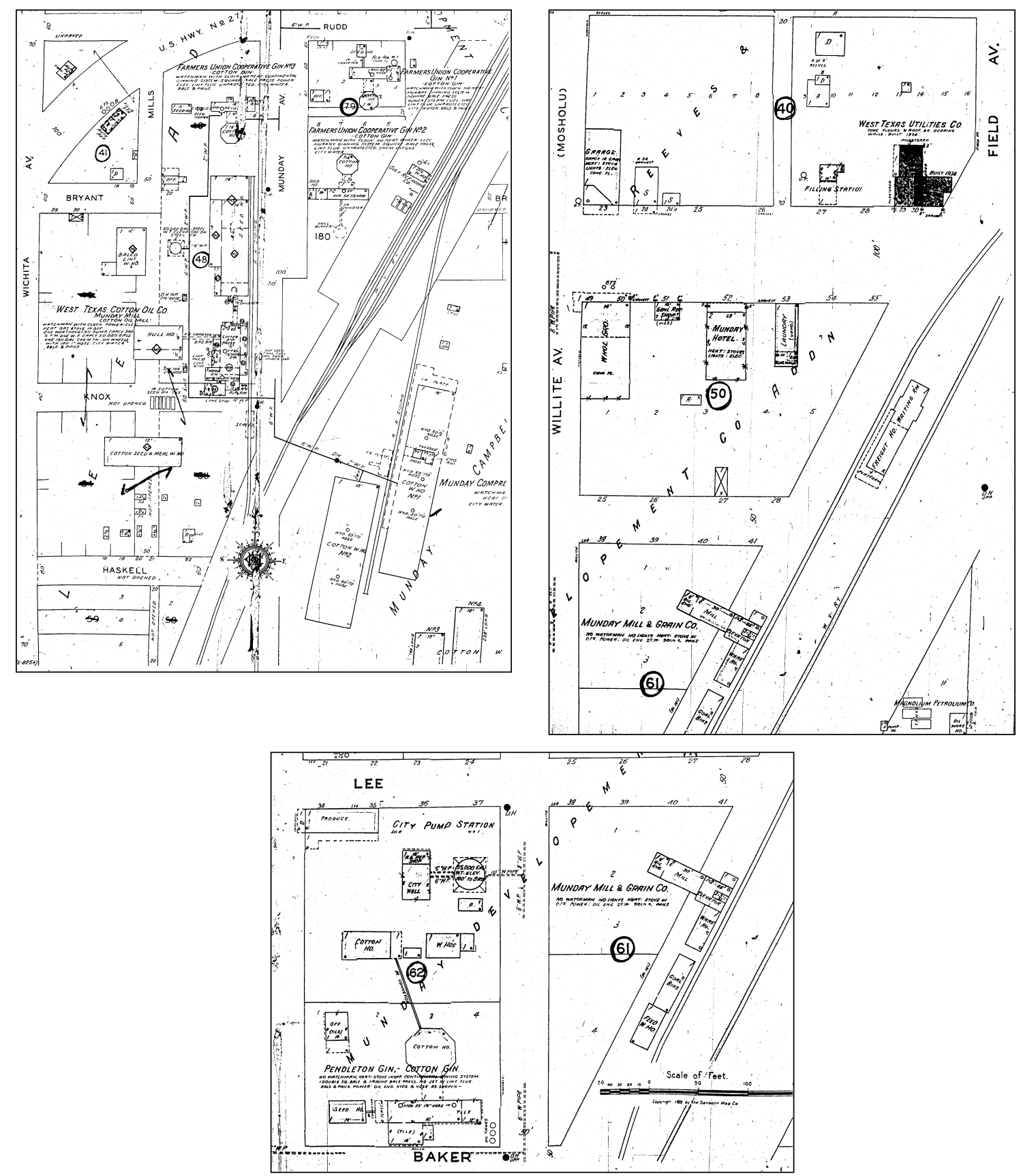

Figure 26. Sanborn maps of portions of Munday, Knox County, Texas, 1942.

drought of the early 1950s. By 1963, cattle ranching was the leading agricultural industry in Wichita County. In Knox County, the League Feed Lot started in 1963 as a way to counter a reduction in cotton acreage. The company emphasized production of grains and feeds for cattle. By the 1980s, Haskell County was largely dependent on ranching, farming, and petroleum, and cotton lost much of its allure as prices fell, expenses rose, and production became difficult in the face of a multiyear drought in the 1990s. During the same period, more than half of Tay- 

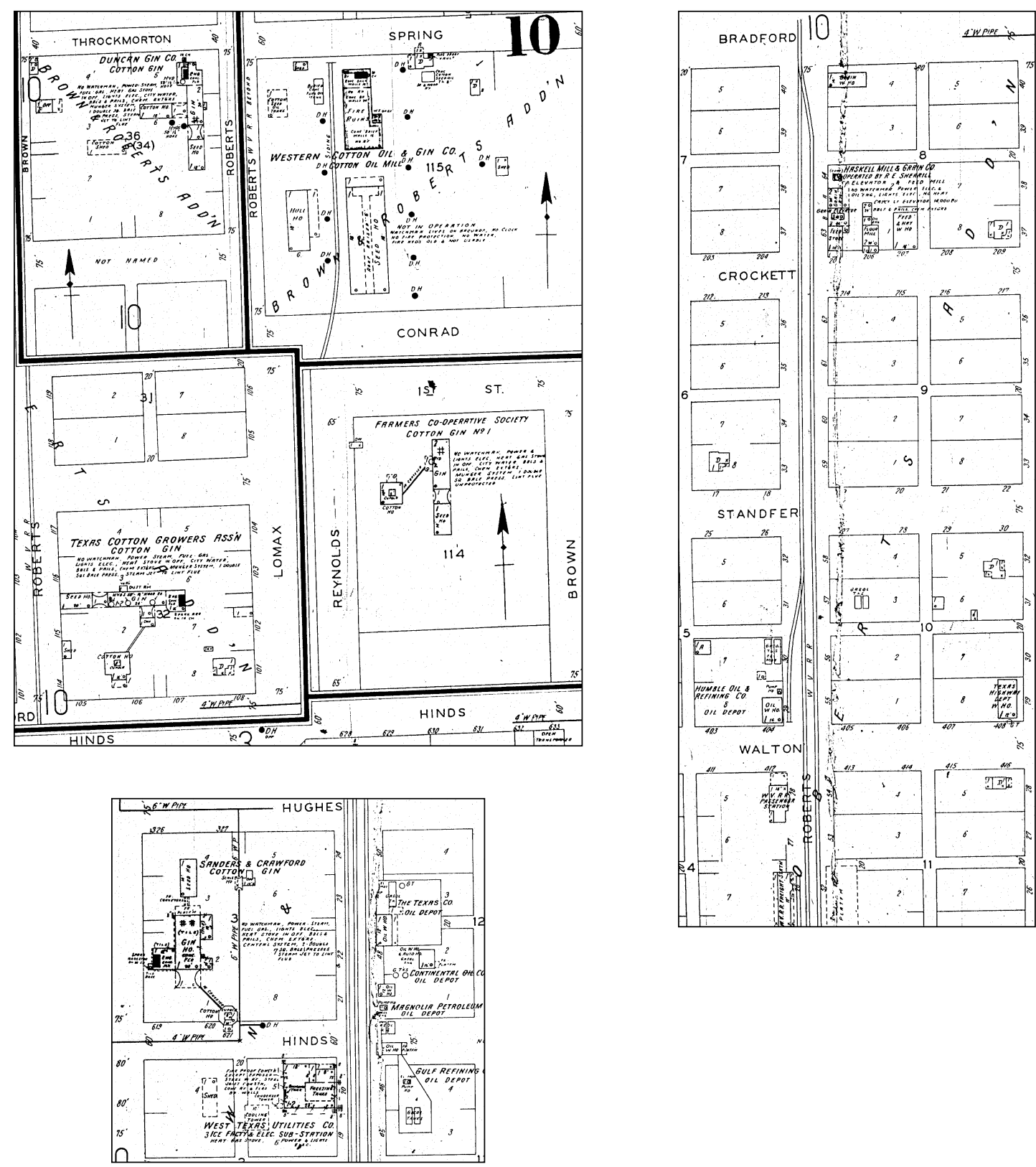

Figure 27. Sanborn maps of portions of Haskell, Haskell County, Texas, 1931. The Farmers Co-operative Society Cotton Gin No. 1 is erroneously located on block 114 instead of on block 95 .

lor County's agricultural income was derived from livestock, a characteristic of the economy that was typical of the project area as a whole (Knox County History Committee 1966:31; Leffler 1996b:224; Sanders and Sanders 1986:111; Tyler 1996b:500; Wichita Program Building Committee 1963:7).

\section{Summary}

The seven-county project area between Wichita County in the north and Taylor County in the south is characterized by soils conducive to commercial-scale agriculture and oil- and gas-bearing geological structures that have been 


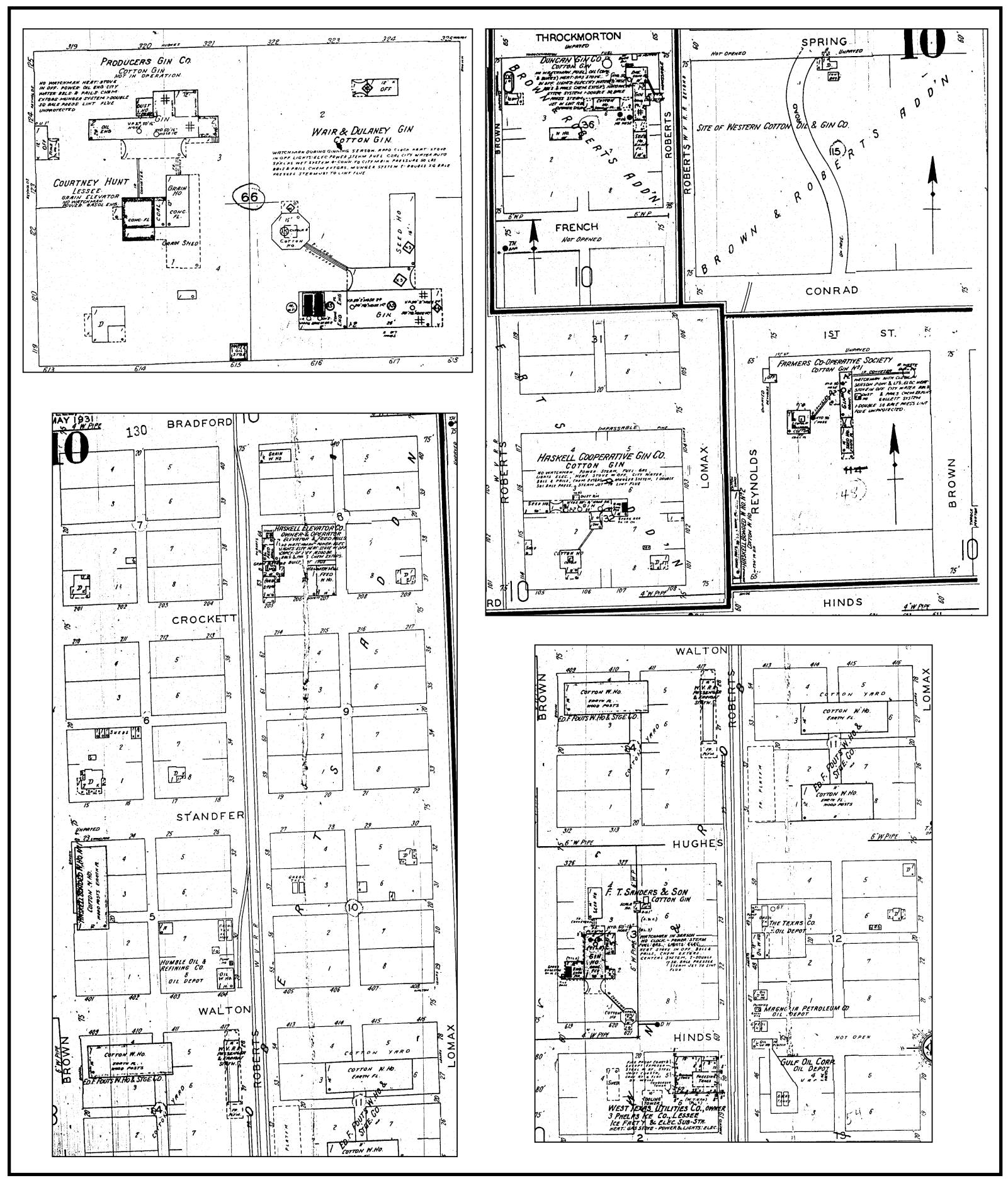

Figure 28. Sanborn maps of portions of Haskell, Haskell County, Texas, 1941.

among the most productive in Texas. The area also is in a marginal climatic region where years of adequate rainfall resulting in abundant crops have created opportunities for capital investment, formation of agriculture-related companies, and construction of agriculture-related improvements. Such episodes have been irregularly but effectively punctuated by years of drought that have 


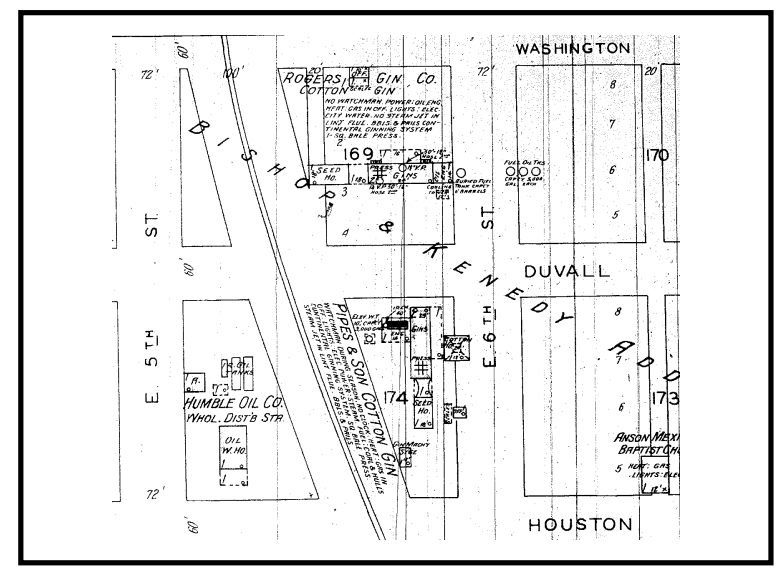

Figure 29. Sanborn map of a portion of Anson, Jones County, Texas, 1930.

ruined crops and resulted in significant emigration cycles and cessation of construction projects.

Development of the full agricultural potential of the region was made possible by the construction of major railroad lines through Wichita Falls and Abilene in the early 1880s and by extension of feeder lines between the two cities through Archer, Baylor, Knox, Haskell, and Jones Counties in 1890 and 1905-1906. Completion of the lines facilitated movements of goods, crops, and livestock during productive years, making commercial agriculture feasible. The railroad also was a mitigating factor in droughty years as it provided seeds to farmers, information about the benefits of crop diversification, and promotional efforts that encouraged immigration to the region.

The earliest period of noteworthy construction occurred in 1881-1884, when a livestockbased economy benefited from favorable weather conditions and the availability of transportation and markets associated with the Fort Worth and Denver City Railroad on the north and the Texas \& Pacific on the south. Improvements clustered around the region's two centers of population-Wichita Falls and Abilene-and occurred sporadically in moreisolated, rural settings.

Drought and severe cold between 1885 and 1887 were followed by beneficial weather conditions that encouraged immigration, the beginnings of concentrated crop production, and consolidation of populations in small towns such as Mankins and Holliday in Archer County and
Goree in Knox County. Attracted by the rate of immigration and convinced of the agricultural productivity of the area, investors built the first railroad feeder line from Wichita Falls to Seymour and tapped into the wheat fields and cattle herds in the region. They bought large tracts of land that they promoted and sold to immigrants. Investors from Wichita Falls also extended their reach along the line, building elevators and mills and purchasing crops in Baylor, Knox, and Haskell Counties. Interest in cotton cultivation increased as well, with the greatest production and largest number of cotton-processing properties occurring in Jones and Taylor Counties.

Agriculture, building, immigration, and the railroads suffered from a drought during the early-to-mid-1890s, but rains returned late in 1896. Agricultural prosperity was accompanied by building projects in Holliday, Seymour, Bomarton, Munday, Stamford, and Abilene, where improvements associated with cotton and wheat processing were constructed, and towns began to improve infrastructure associated with public services such as telephone lines and electrical and water systems. Crop production and continuing immigration also encouraged railroad investors to extend the rail lines once again, and a route was chosen only after a careful examination of soils and crops, the rate of immigration, and available water resources.

Completion of lines from Seymour to Stamford and from Abilene to Stamford in 1905-1906 was followed by population growth, formation of new towns such as Weinert in

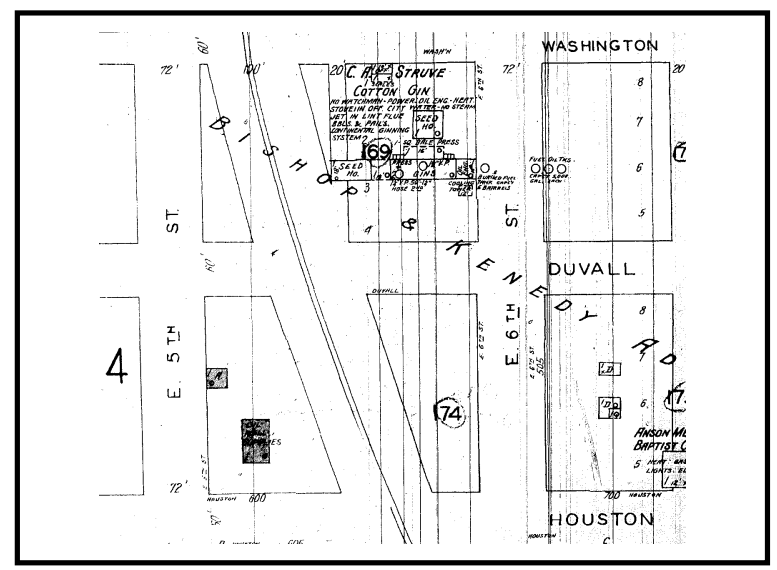

Figure 30. Sanborn map of a portion of Anson, Jones County, Texas, 1939. 
Haskell County, and new construction of agricultural processing facilities until approximately 1908, when the first of several droughts ruined crops. For approximately 3 years, crops failed, farmers emigrated, and the railroad lost income. Construction came to a standstill except in the northern part of the project area where early oil production attracted workers and sparked building episodes in Wichita County.

Improvement in weather conditions between 1912 and 1916 was accompanied by large crop yields and new building projects in towns along the rail line, but it was followed by the worst drought in 60 years. Counties lost most of their populations in 1917-1918 as emigrants flooded to the booming oil fields of Wichita County, they recuperated only after record rains and crop production in 1919.

An extended period of prosperity, largely based on the strength of cotton cultivation, occurred between 1919 and the late 1920s and was accompanied by growth of town and county populations, increases in the numbers of farmers and acres of land cultivated, construction of agricultural processing facilities, and development of alternative sources of water. The strength of the oil and gas industry is revealed, as well, in the spread of marketing facilities along the length of the project area, construction of roads, and the increasing availability of cars and trucks.

The spread of the boll weevil in the late 1920s and the effects of a national depression in the 1930s placed burdens on agricultural production. However, while counties lost population during the 1930s, towns in the project area grew, and facilities associated with cotton and wheat processing not only persisted but even expanded in some communities.

The 1950s saw a movement away from an emphasis on cotton cultivation and a renewal of emphasis on wheat and stock raising. Cultural properties such as feed lots became increasingly common, while the number of properties associated with cotton processing declined.

\section{A HISTORY OF THE DEVELOPMENT OF THE COTTON INDUSTRY AND COTTON-RELATED PROPERTIES IN HASKELL, HASKELL COUNTY, TEXAS}

Haskell County, Texas, in the North Central Plains division of Texas (see Figure 2), is characterized by a rolling landscape that is drained by tributaries of the Brazos River. Soils are sandy and gray, black, and chocolate loams that provide fertile sustenance for short grasses and are readily cultivated. The average rainfall for the county is 24.14 inches, approximately the average for the seven counties between Taylor and Wichita Counties through which U.S. Highway 277 passes.

Anglo-American exploration of the area occurred first in 1849 when an immigrant group crossed California Creek in the southeast part of Haskell County. A member of the group described the area, and 6 years later, William Armstrong and I. G. Searcy led a party to survey the land (Leffler 1996a:501). According to Biggers (The Haskell Free Press, September 8, 1906:2), Armstrong also discovered a set of springs near the present-day Haskell townsite while establishing lines and boundaries.

The Texas legislature established Haskell County on February 1, 1858, carving it out of Shackelford County (Felker 1975:5; [Haskell County (Tex.)], Program Building Committee 1970:n.p.), but even tentative settlement was delayed because of Indian hostilities during the 1850 s and 1860s. John Goff's enthusiasm for Paint Creek in the southwest part of Haskell County was only temporary, and the buffalo hunters who moved in were not interested in permanently locating there (Leffler 1996a:501; Sanders and Sanders 1986:1; Sherrill 1965:49, 63). Decimation of the herds in the mid-to-late 1870 s, however, removed the Indian threat, and the first permanent settlers-George $\mathrm{T}$. Reynolds and J. A. Matthews and their wivesmoved to California Creek where they built a stone ranch house (The Haskell Free Press, September 8, 1906:7; Sherrill 1965:54,63). They soon moved away, and their place was taken by Thomas F. Tucker, who occupied the stone ranch until at least the mid-1880s (The Haskell Free Press, September 8, 1906:7; Sherrill 1965:5556). Rice Springs near present-day Haskell was rediscovered, as well, by Ryus Durrett (Clary 1956:181; Sherrill 1965:54-55).

Although some limited farming was done by the late 1870 s, when R. D. Wilfong grew corn, sorghum, and melons on the Double Mountain Fork of the Brazos River in western Haskell County (The Haskell Free Press, August 11, 1906:1), cattlemen and their herds were dominant. By 1880, 48 individuals were living in the 
county (see Table 1), and they were joined soon after by more ranchers eager to move their herds to the fertile grasslands. Cattle prices doubled in 1882, and rains and grass were abundant, leading to a boom that lasted until 1885 (Sherrill 1965:51, 52). At the same time, a small community began to take form at Rice Springs. W. R. and Elbridge Standifer (also spelled Standefer) built a log hut at the springs in early 1883 (The Haskell Free Press, August 11, 1906:9; Sherrill 1965:56), and they were joined by an individual named Thistle, who built a log house near the future square, and by John Labririe, who built a small home nearby. The new settlers used elm and hackberry logs to construct cabins; a few hauled lumber for frame buildings from Abilene. Commercial construction was limited and consisted of two small stores (The Haskell Free Press, August 18, 1906:9).

By late 1884, the community had a large enough population to file a petition for county organization. Haskell County was officially organized in January 1885, and the town of Haskell near Rice Springs was selected as the county seat ([Haskell County (Tex.)], Program Building Committee 1970:n.p.; Leffler 1996a:501). Within a year, the citizens had built a frame courthouse and a jail. W. F. Draper and J. L. Baldwin established a grocery store, which soon received competition from businesses opened by William Harvey and L. M. Smith, all constructed on the courthouse square. In the county, individuals such as G. W. Cook had begun to experiment with crops; Cook planted a large crop of millet, sorghum, hay, and wheat during 1886, despite a persistent drought that ruined spring crops (The Haskell Free Press, January 1, 1926:1; Sherrill 1965:99).

The drought and hard winters of 1885-1887 were less kind to ranchers, who had overstocked the ranges. According to Sherrill (1965:64), approximately 30 to 40 percent of the cattle died, and thousands of sheep were lost as well. Small farms that had opened were abandoned, and the country around Haskell was thought to be "wholly unfit for farming" (Sherrill 1965:64). But the drought broke in April 1887, and the response by potential settlers, businesses, developers, and farmers was rapid and dramatic. By mid-1887, there were 10 businesses in Haskell, 6 law firms, 4 land companies, and numerous carpenters despite the drought that had "very much retarded the development of the county ..." (The Haskell Free Press, January 1, 1926:1). About the same time, a developer acquired 50,000 acres to subdivide and sell to farmers (Sherrill 1965:110). Within 2 years, 30,000 acres of land sold, and immigrants poured into Haskell County using the recently surveyed Haskell-to-Benjamin and Haskell-toSeymour Roads (Sanders and Sanders 1986:3; Sherrill 1965:110, 112).

On October 13, 1887, George Baggett (also spelled Baggot) sold the first bale of cotton raised in Haskell County (Sherrill 1965:110), and 2 years later, J. L. Jones and N. C. Smith erected a gin on the block east of the square in Haskell where they ginned cotton brought from as far away as Dickens and Cottle Counties (Sherrill 1965:76, 112) (Table 3; Figure 31). With construction of the Wichita Valley Railway to Seymour, only 4 miles to the northeast, Haskell's citizens began to agitate, as well, not only for an extension of the rail to their own town, but for construction of a mill in Seymour so that Haskell County farmers would have a convenient outlet for their substantial wheat crops (The Haskell Free Press, November 22, 1890:4). In November 1890, The Haskell Free Press boasted that the wheat crop along the Double Mountain and Salt Forks of the Brazos River looked so promising that flat boats would be necessary to carry all of it out. If only Seymour would build a roller mill, that town would benefit from the countryside that was tributary to it (The Haskell Free Press, November 22, 1890:4).

In the early 1890s, Haskell lobbied hard for its own rail line. But plans by likely investors were shelved following the 1893 Panic and the drought and hard winters of 1896-1898. Crops were short, cattle and sheep prices were low, and the two-bank town became a town of one as the First National Bank sold out to the Haskell National Bank (Felker 1975:16; Sherrill 1965:65-66, 77, 114). As many as 25 percent of the farmers in Haskell, Jones, and adjoining counties left (Sherrill 1965:113) and did not return until 1898, after a good season of weather and crops in 1897 induced immigration. In 1899, Haskell County produced 830 bales of cotton, and farmers poured into the area, encouraged by both the crops and prices (Sherrill 1965:68, $79,114)$. The cotton crop increased to 2,510 bales the next year, when the county had 256 agricultural units and cotton cultivation had expanded 
to 3,674 acres (Leffler 1996a:501; Sherrill 1965:114-115).

Agricultural prosperity encouraged railroads to look at the region and build lines through it. The first trains of the Texas Central ran into Stamford in early 1900, and a committee went to Sweetwater in 1901 to try and convince the managers of the Kansas City, Mexico and Orient to route their road through Haskell (Sherrill 1965:165). Perhaps in anticipation of such construction, William A. Earnest and F. T. Sanders purchased lots 5-6, block 15, Haskell, from William E. Hughes of Arapahoe County, Colorado, on July 1, 1901, and constructed a cotton mill soon after (Deed Record 16:504) ${ }^{8}$ (see Table 1). In 1902, the railroad committee contacted Morgan Jones to try and induce him to extend the Wichita Valley line from Seymour, but the effort failed when Jones cancelled the agreement (Felker 1975:4; Sherrill 1965:165). The following January, C. C. Waller and M. W. Whittemore of Chicago contracted with the committee to build the Omaha, Kansas \& Texas Railroad, and in August, M. L. Healey offered to contract for construction of the Denton, Decatur \& Western Railroad through Haskell (Sherrill 1965:16, 165-166). But despite all the smoke, there was no fire, and Haskell in 1904 found itself tantalizingly close to the Texas Central in Stamford and the Wichita Valley in Seymour, but without a railroad of its own.

According to Sherrill (1965:166-167), it was the committee's 1905 negotiations with J. D. Beardsley, who agreed to build a rail line from Abilene to Haskell, that convinced Morgan Jones to negotiate with Haskell to extend the Wichita Valley line south from Seymour. In October, the committee agreed on a contract with Jones, whose surveyors were in the field the next month.

Rumors of a railroad and good cotton crops attracted the attention of farmers from other parts of the state that were suffering from early boll weevil infestations. ${ }^{9}$ Haskell's numerous real estate agents heavily promoted the county to Central Texas farmers, in particular those from the cotton-growing center of Bell County. Haskell Real Estate Company, for example, opened offices in Temple and Belton (Bell

\footnotetext{
${ }^{8}$ All county-level legal records cited here are for Haskell County.
}

County), Taylor (Williamson County), Waco and Mart (McLennan County), Hubbard City (Hill County), Gatesville (Coryell County), Rosebud (Falls County), and Whitewright (Grayson County), while Buie and Sparks announced plans to open an office in Taylor (Williamson County) (The Haskell Free Press, December 23, 1905:4; January 6, 1906:5; February 2, 1906:5). The promotional efforts soon bore fruit: in 1.5 months The Haskell Free Press announced the arrivals of H. L. Sherrill of Temple; J. H. Rogers, Will Dwyer, J. M. Carlisle, J. C. Carlisle, and A. J. Pryor of Bell County; and C. S. Burns and G. B. Hooper of Williamson County, all of whom had bought Haskell County farms. Morgan Brothers of Hill County bought lots in Haskell to build a lumberyard, and W. A. Flowers of McLennan County made a proposal to the executive committee of the Commercial Club to build an ice, electric light, and water plant (The Haskell Free Press, December 23, 1905:1, 5; December 30, 1905:5; January 20, 1906:5; January 27, 1906:5; February 3, 1906:8).

The strong wave of immigration from the Blackland Prairie brought farmers and investors who were deeply involved in cotton culture, and production of that crop boomed in Haskell County, reaching 9,043 bales in 1904, 13,948 in $1905,11,678$ in 1906, and 23,207 in 1907 before falling to 19,667 in 1908 and 15,050 in 1909 (Sherrill 1965:118), when drought returned to the region (see Figure 7). Naturally, improvements related to cotton culture soon became the talk of Haskell. In December 1905, Cason, Cox \& Company were rumored to be making preparations to build a large warehouse (The Haskell Free Press, December 23, 1905:5), and construction actually started on the south side of the original townsite early in February 1906 (The Haskell Free Press, February 3, 1906:5; Sherrill 1965:116) (see Table 3). In January 1906, the Haskell Commercial Club met to discuss the need for a cottonseed oil mill. Members resolved

\footnotetext{
${ }^{9}$ According to The Haskell Free Press (May 19, 1906:6), using statements provided by the Department of Agriculture, the counties beginning with Throckmorton and extending west from Haskell almost doubled their production of cotton between 1904 and 1905, while the counties in a large part of Central and East Texas "fell far short" in 1905 of their 1904 crops.
} 


\begin{tabular}{|c|c|c|c|c|c|c|c|c|}
\hline 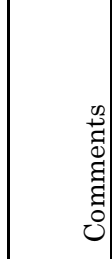 & & 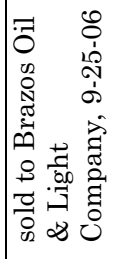 & & & 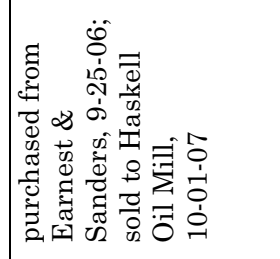 & 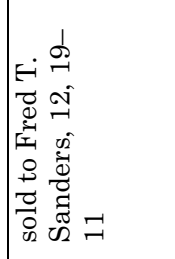 & \multicolumn{2}{|c|}{ 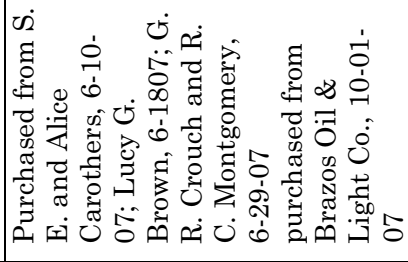 } \\
\hline 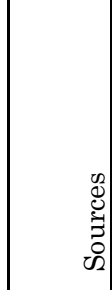 & 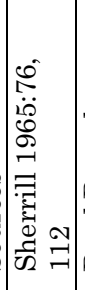 & 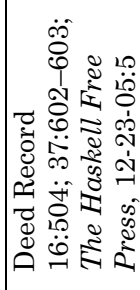 & 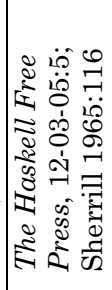 & 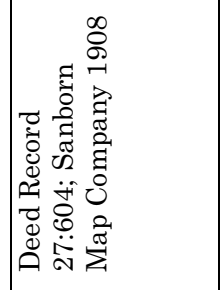 & 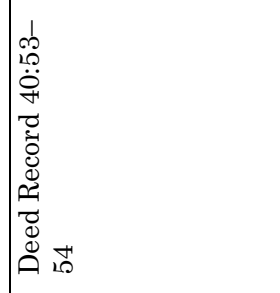 & 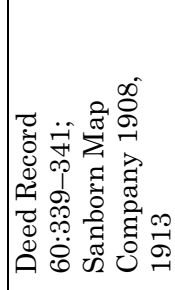 & 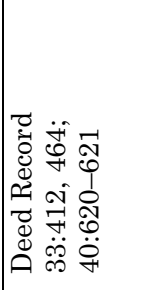 & 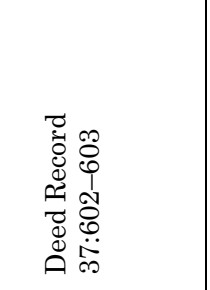 \\
\hline 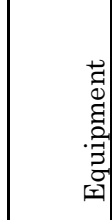 & & 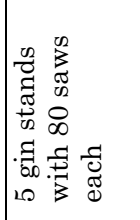 & & & 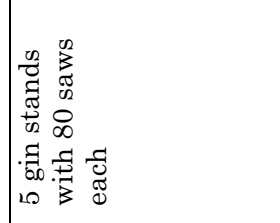 & 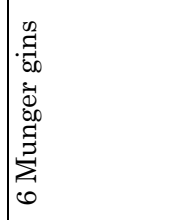 & $\begin{array}{l}: \vec{z} \\
\frac{\vec{\Xi}}{0}\end{array}$ & 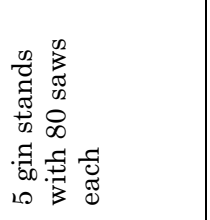 \\
\hline 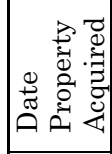 & 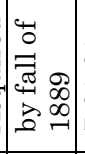 & $\begin{array}{l}\overrightarrow{0} \\
0 \\
0 \\
0 \\
1 \\
\end{array}$ & 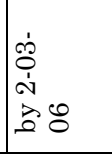 & $\begin{array}{l}0 \\
0 \\
0 \\
\infty \\
\infty \\
\infty\end{array}$ & 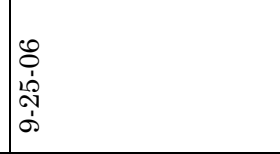 & 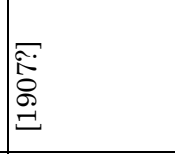 & $\begin{array}{l}5 \\
0 \\
\dot{0}\end{array}$ & $\begin{array}{l}5 \\
\stackrel{1}{1} \\
0 \\
\dot{1} \\
-1\end{array}$ \\
\hline 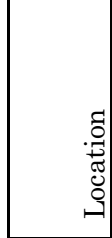 & 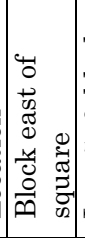 & 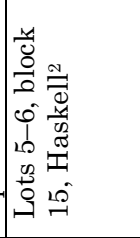 & 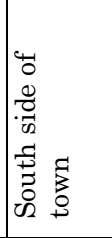 & 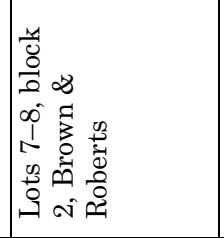 & 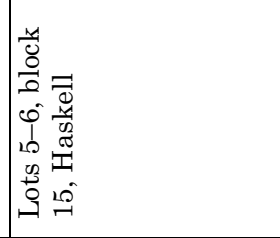 & 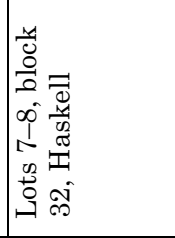 & 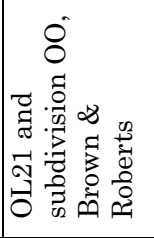 & 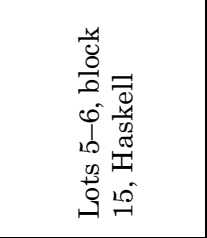 \\
\hline 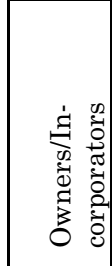 & 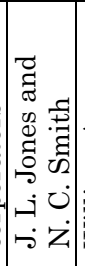 & 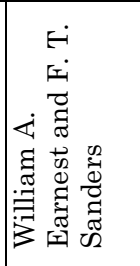 & 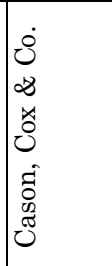 & 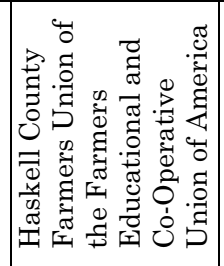 & 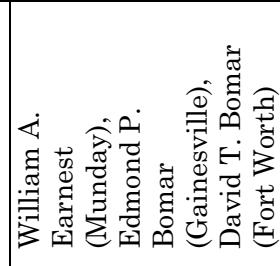 & 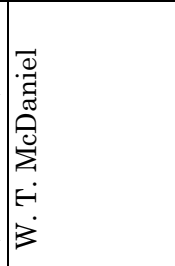 & 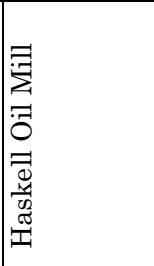 & \\
\hline 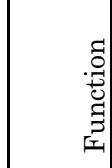 & 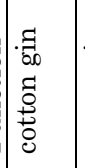 & 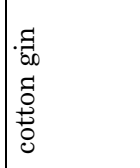 & 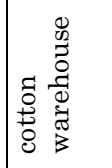 & 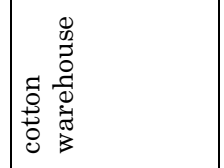 & 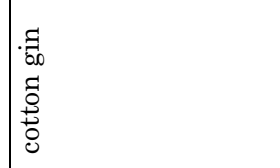 & 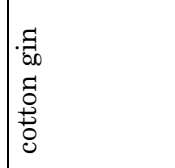 & 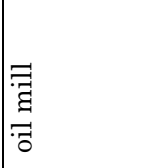 & 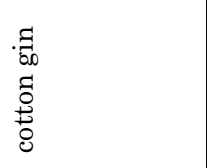 \\
\hline 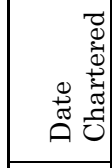 & & & & & $\stackrel{8}{\&}$ & & & \\
\hline 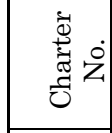 & & & & & 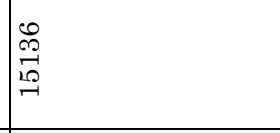 & & & \\
\hline z్ & 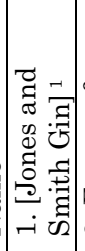 & 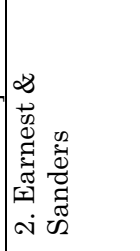 & 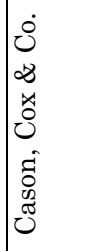 & 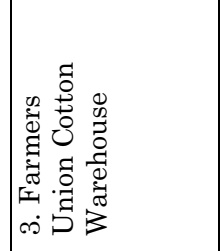 & 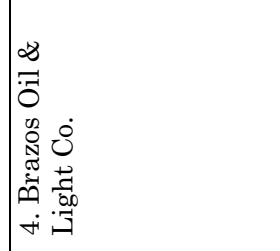 & 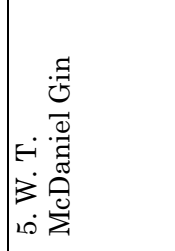 & 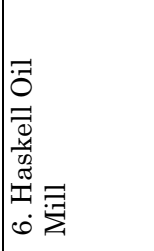 & \\
\hline
\end{tabular}




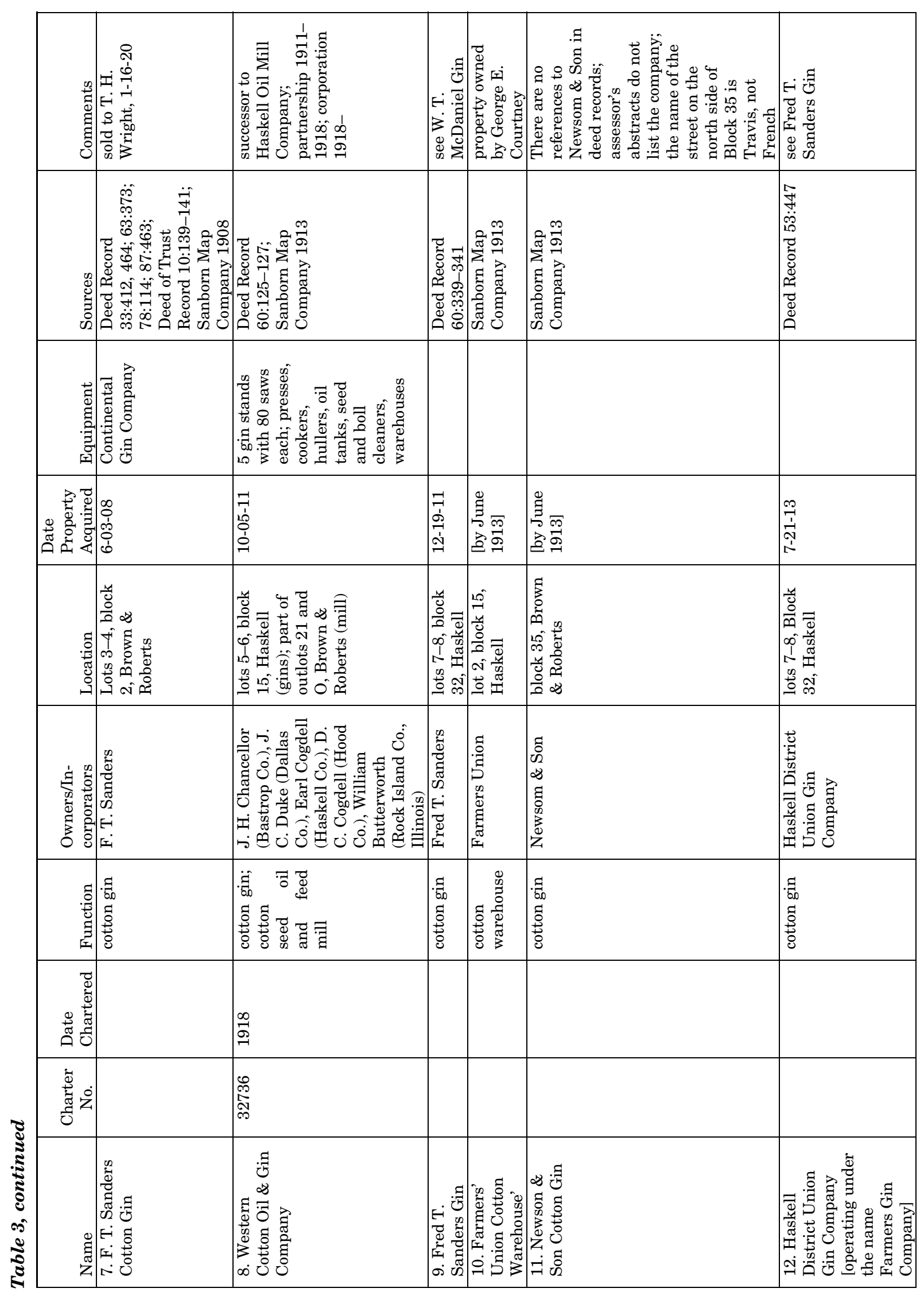




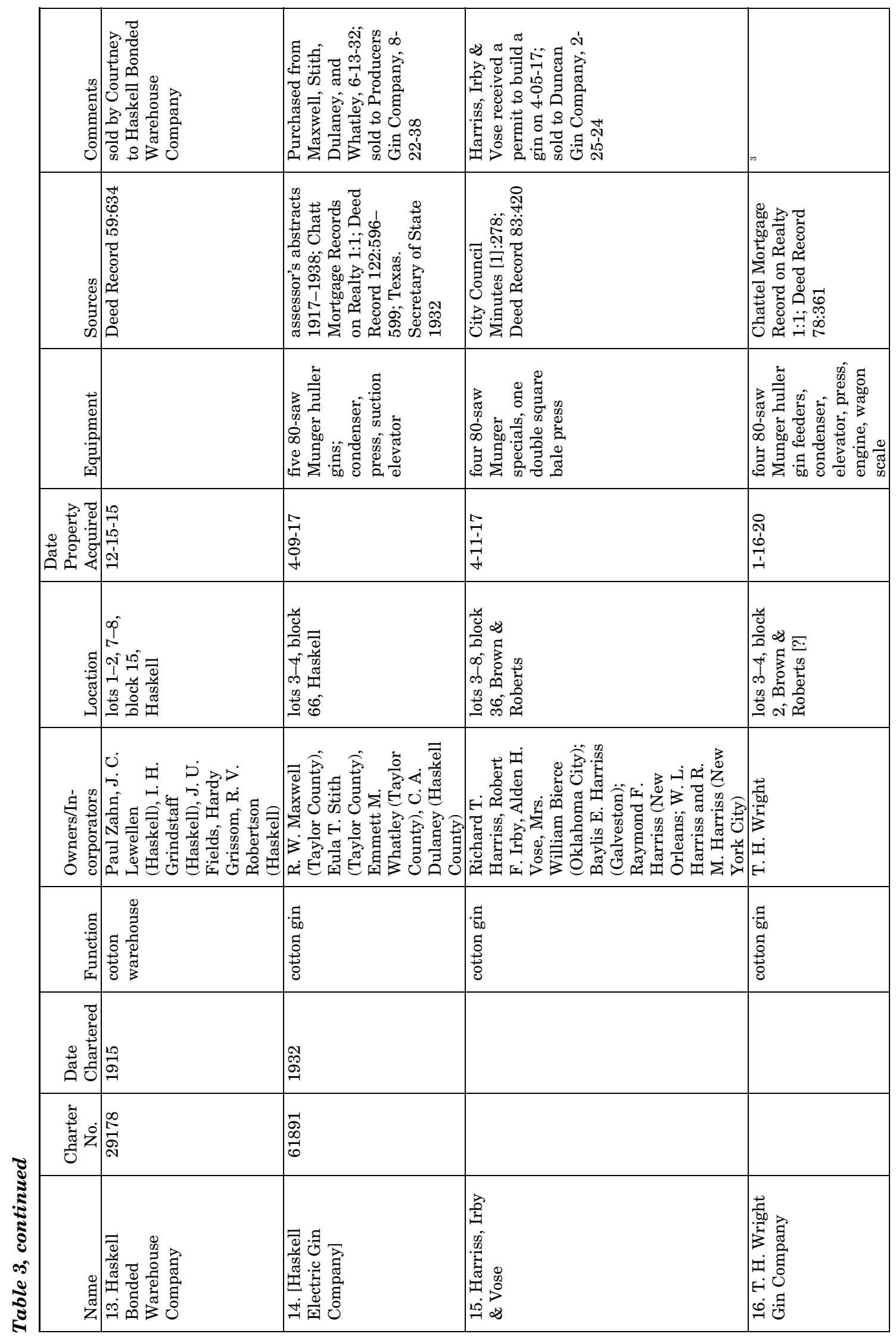




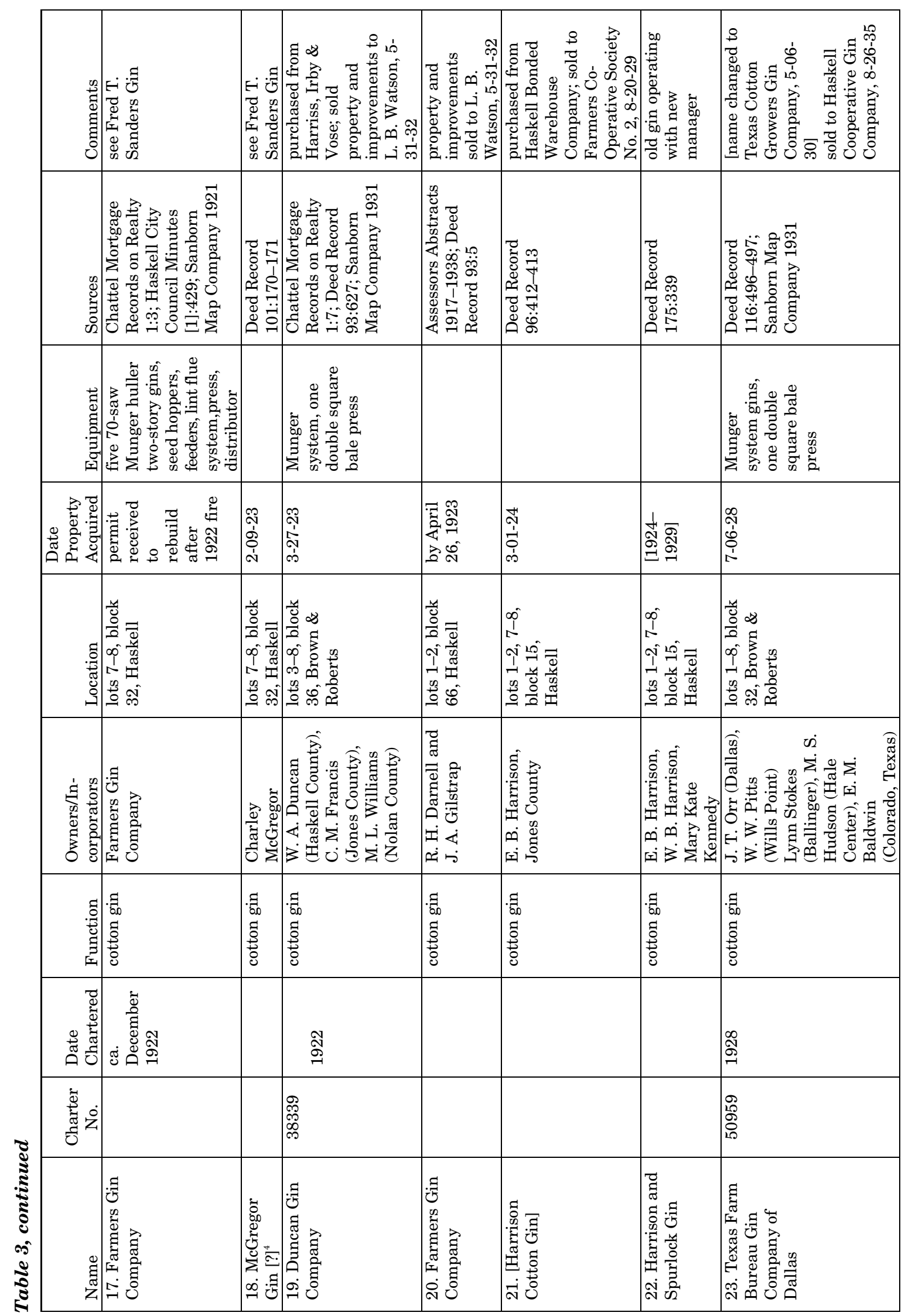




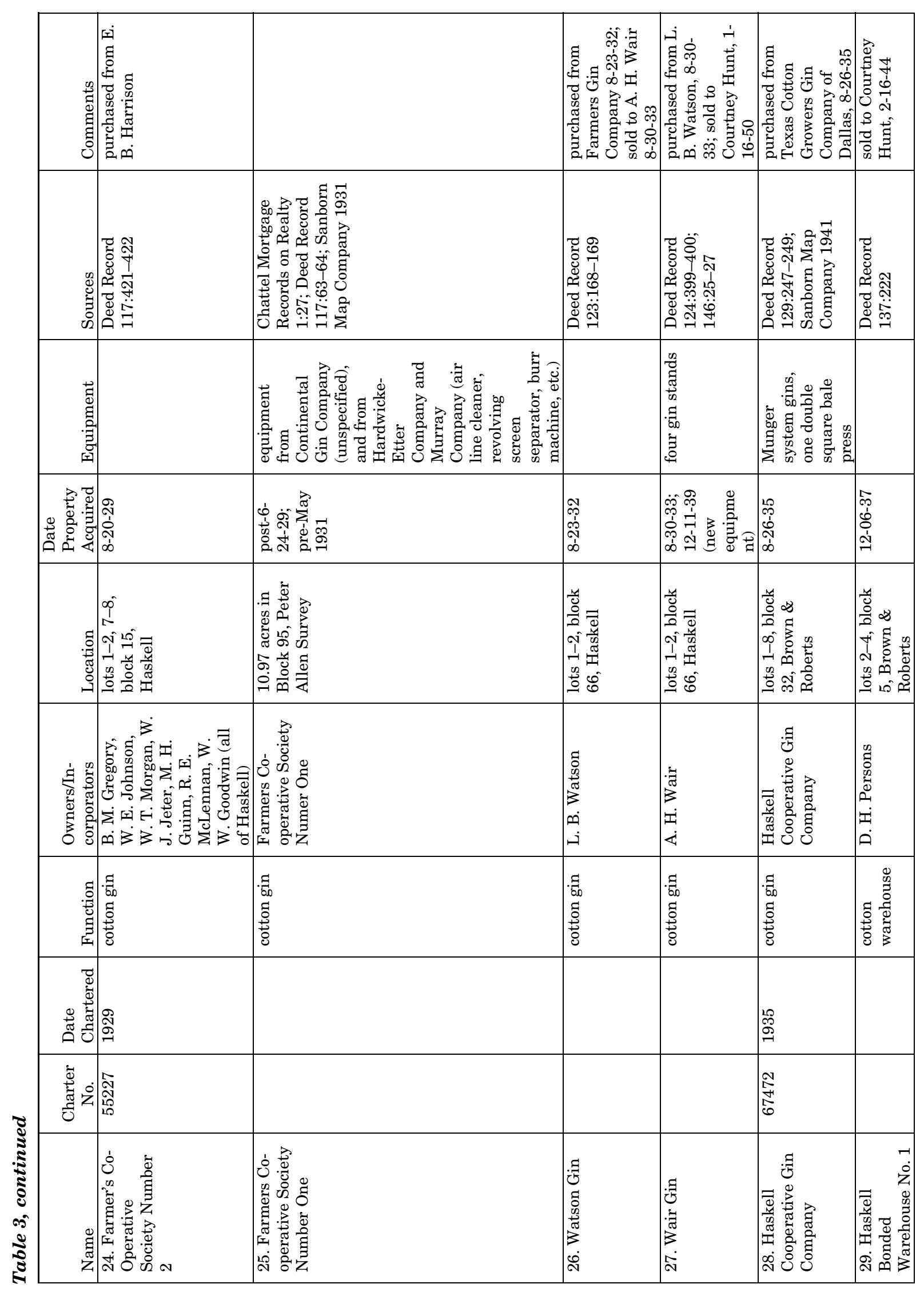




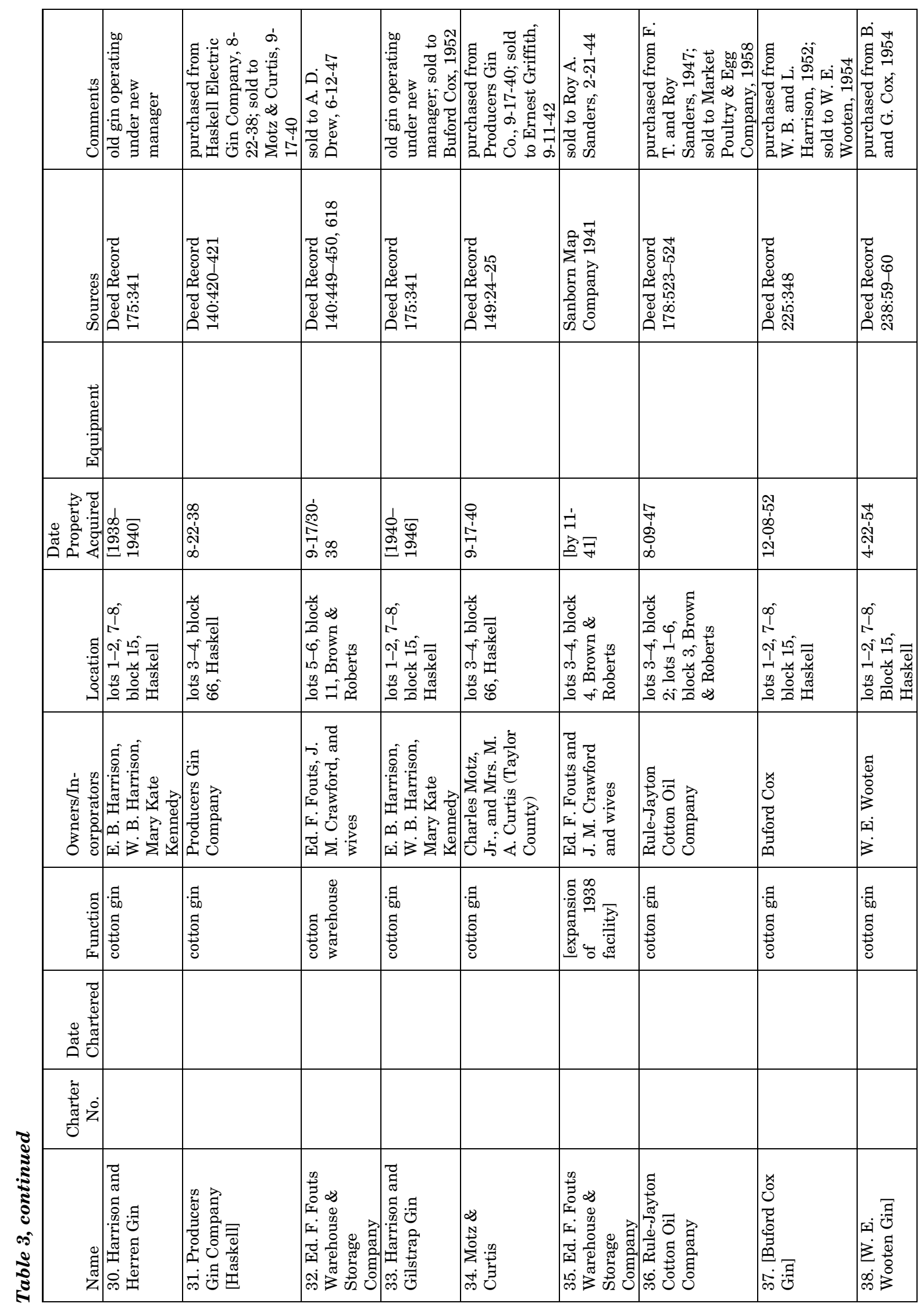




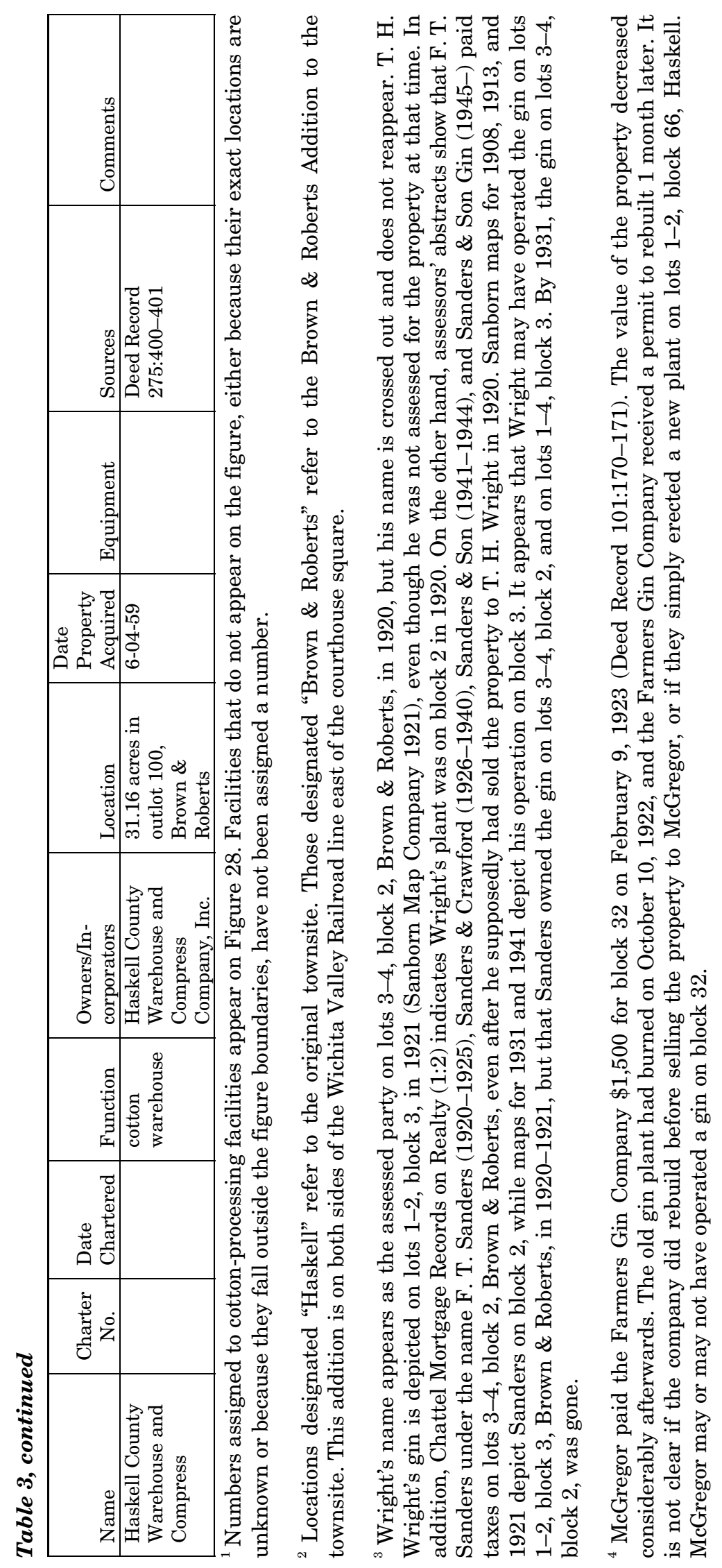




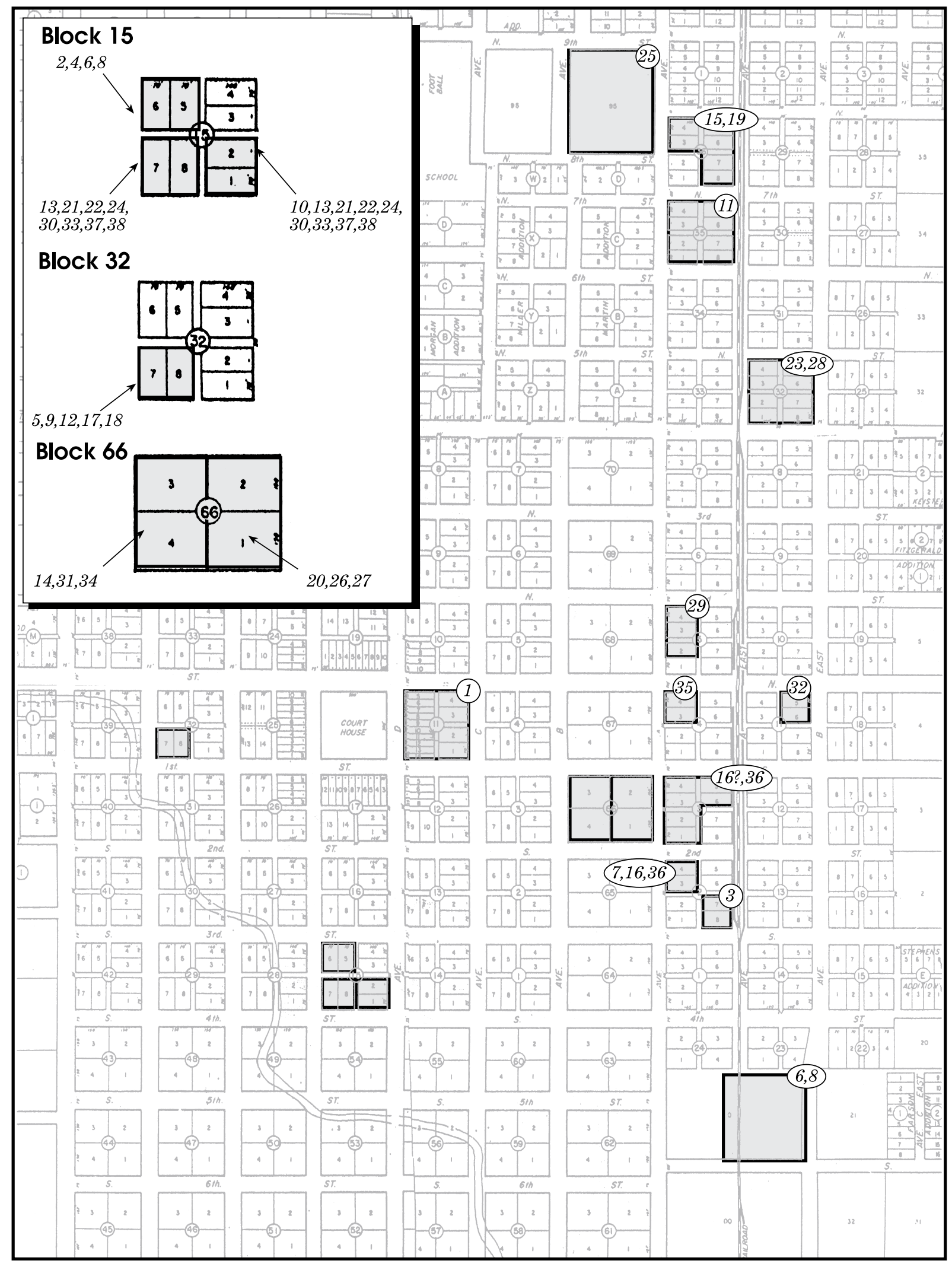

Figure 31. Cotton-processing facilities in Haskell, Haskell County, Texas, ca. 1889-2002. (Information is taken from Haskell city council minutes; Haskell County deed, deed of trust, chattel mortgage, lien, and probate records; and secretary of state corporation records.) 
to organize and charter a company to fund construction of a $\$ 40,000$ oil mill, and an initial solicitation of subscriptions raised several thousand dollars "in a few minutes." Other businessmen at the meeting pledged to begin construction of large stone or brick business houses in town (The Haskell Free Press, January 20, 1906:1).

As grading on the new railroad moved southward from Seymour, The Haskell Free Press editorialized about the advantages that a cottonseed oil mill, flour mill, and public utilities would bring to Haskell. The newspaper drew its readers' attention to the number of people who came to town because there was a gin there (Earnest \& Sanders Gin). Those visitors benefited the community because they did other business while there. Many others would come if there were an oil mill (The Haskell Free Press, February 17, 1906:4). Perhaps encouraged by the prospects of serving all those new visitors, and knowing of the recent immigration from the Blackland Prairie area, C. D. Long of Haskell County; William B. Brazelton, Charles L. Johnson, and W. W. Pryor of McLennan County; and Charles Brewington of Jones County incorporated the Haskell Lumber Company on March 16, 1906 (Texas. Secretary of State $1906 \mathrm{~b})$. The same month, a group of Haskell citizens formed the Haskell Ice, Light and Water Company (also appears as the Haskell Light, Ice and Water Company and Haskell Light, Ice \& Water Company) with a capital stock of $\$ 20,000$ (The Haskell Free Press, April 14, 1906:8).

Substantive action to build improvements for the processing of cotton and cotton products lagged, however. No apparent progress had been made in planning for mills or new gins, and on August 2, 1906, when the Wichita Valley rails were laid into Haskell, the town was still a onegin community despite the newspaper's designation of it as the "Queen City of the West" (The Haskell Free Press, August 4, 1906:1). Indeed, only the Haskell County Farmers Union appears to have been active. After purchasing lots 7-8, block 2, Brown \& Roberts Addition, on August 30, 1906, from Joe Irby of the light company (Deed Record 27:604), the Union set about to erect a cotton warehouse immediately west of the new rail line and south of the future Haskell Light, Ice and Water Company (see Table 3, Figure 9) (Sanborn Map Company
1908). The iron-clad building was intended to hold cotton so that the farmers union could better reap the rewards of holding crops until prices were good, purchasing seed when prices were low, and dealing directly with consumers (The Haskell Free Press, June 9, 1906:10). On the other hand, the much-heralded Brazos Oil \& Light Company failed to build a new oil mill at all, choosing instead on September 25, 1906, to purchase Earnest \& Sanders's older gin outfit that consisted of five gin stands with 80 saws each on lots 5-6, block 15, Haskell townsite (Deed Record 40:53-54) (see Table 3, Figure 32). ${ }^{10}$

Very little cotton manufacturing activity occurred during the balance of 1906, but the next year a new plant with six Munger gins was constructed on lots 7-8, block 32, Haskell, by W. T. McDaniel (see Table 3). McDaniel, who contracted with Continental Gin Company to outfit his property, built a gin building, seed room, and seed house. Fuel was coal, wood, and oil; lights were electrical; and water was provided from an elevated water tank that filled from a well next to the gin building (Assessors Abstracts of City Lots 1907; Probate File No. 190; Sanborn Map Company 1908) (see Figure 32). Later that year, in October 1907, the Brazos Oil \& Light Company sold its gin on lots 5-6, block 15, Haskell, to the Haskell Oil Mill Company, which also was busy acquiring land adjacent to the rail line in block 14 and in outlots $\mathrm{O}$ and $\mathrm{OO}$ of the Brown \& Roberts Addition (Deed Record 33:412, 464, 531; 37:602-608; 40:620621) (see Table 3).

10 The Brazos Oil \& Light Company was incorporated by William A. Earnest of Munday (F. T. Sanders's partner in the gin on block 15), Edmond P. Bomar of Gainesville, and David T. Bomar of Fort Worth (on the board of directors for the Wichita Valley Railroad). They formed the company on January 3, 1906, for the purposes of constructing or purchasing and maintaining mills and gins; manufacturing and supplying ice, gas, light, heat, water, and electric motor power; and erecting mills for the manufacture of cottonseed products. The principal place of business was in Munday; a branch office was in Seymour. Capital stock was $\$ 75,000$, and the board of directors were residents of Munday, Seymour, Wichita Falls, Gainesville, Sherman, and Fort Worth. The principal place of business changed to Dallas on August 30, 1906 (Texas. Secretary of State 1906b). 

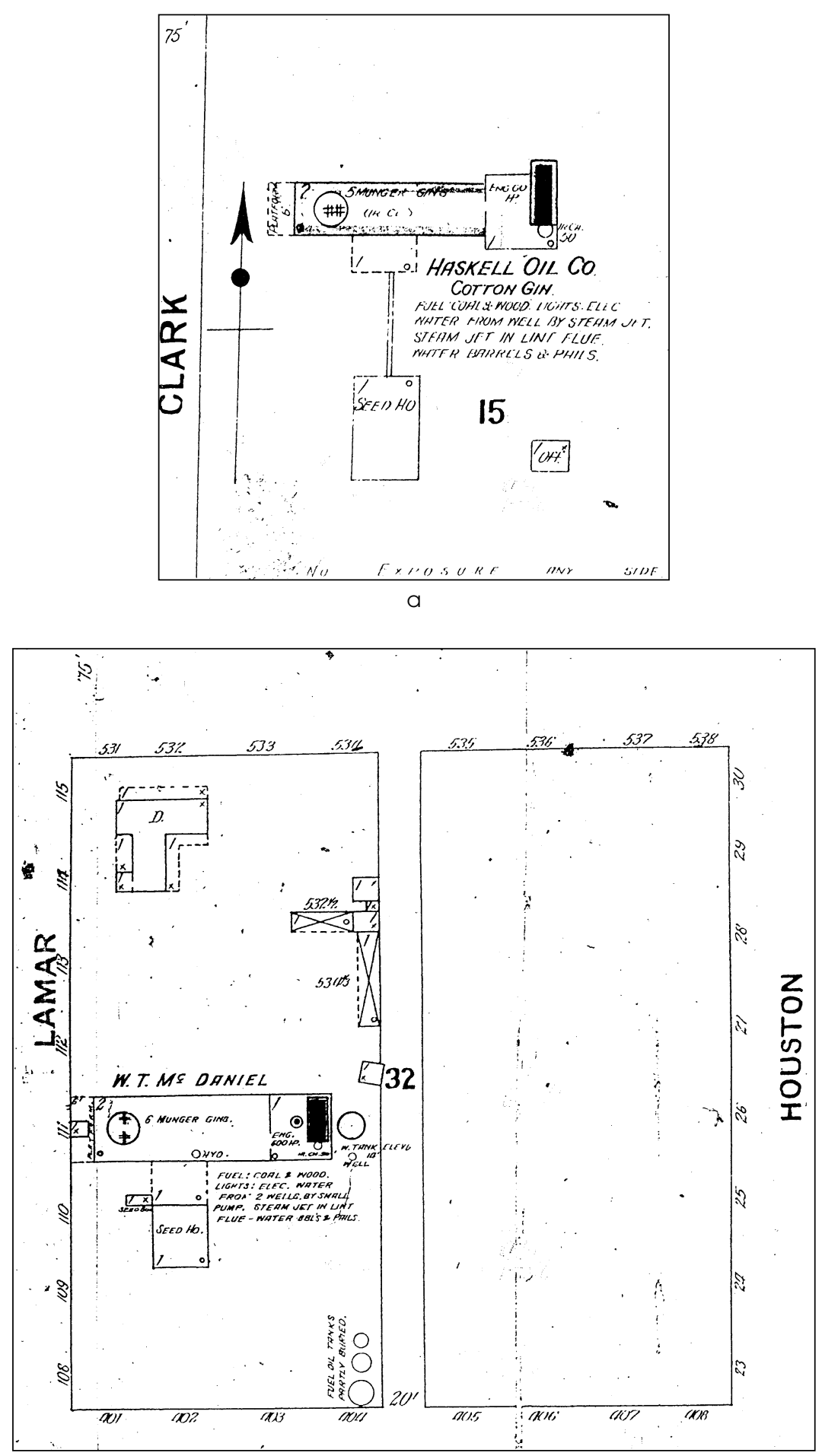

b

Figure 32. Sanborn maps. (a) Haskell Oil Company Cotton Gin on block 15, Haskell. In 1906, this plant was owned by the Brazos Oil \& Light Company; (b) W. T. McDaniel Cotton Gin on block 32, Haskell. 
Perhaps encouraged by the record cotton crop of 1907 (see Figure 7), the Haskell Oil Mill Company kept its gin running on block 15, Haskell, and committed to building a new oil mill on blocks $\mathrm{O}$ and OO, Brown \& Roberts Addition, adjacent to the Wichita Valley line (Sanborn Map Company 1908) (see Table 3, Figure 9). They made verbal contracts with the Haskell Lumber Company and McNeill \& Smith Hardware to provide materials for the plants. However, the Haskell Oil Mill Company failed to pay, and the lumber and hardware companies filed liens against the property in March 1908 (Materialsman Lien 1:72-74, 78-87). Weighted down by its debts, including a debt to the gin manufacturing Murray Company of Dallas County, the board of the Haskell Oil Mill met on September 16, 1908, and authorized its president, Carl Cogdell, to borrow $\$ 10,000$ from the First State Bank of Smithville so that the company could pay its debts and place its mills and gins in operation (Deed Record 91:361-362; Deed of Trust Record 8:226-232). The company was successful in its application, and for a time it was out of the financial woods and able to operate its concrete brick mill (Sanborn Map Company 1908).

In the meantime, Earnest's former partner, F. T. Sanders, was having more success with his own business. On June 3, 1908, he purchased lots 3-4, block 2, Brown \& Roberts Addition, near the new rail line immediately west of the Haskell Light, Ice and Water Company plant and the Farmer's Union Cotton Warehouse and began construction of a cotton gin that he furnished with Continental Gin equipment (Deed Record $33: 412$, 464; 63:373; 78:114; 87:463; Deed of Trust Record 10:139-141; Sanborn Map Company 1908) (see Table 3, Figure 9). However, the storms and worms of 1909 that cut the cotton crop short, drought in 1910 and 1911, and a grasshopper scourge in 1913 took their toll (Sherrill 1965:117-120). The note held on the property belonging to the Haskell Oil Mill came due, and the company was unable to pay. As a result, the First State Bank of Smithville forced a sale of the property, which included lots 5-6, block 15, Haskell; outlots O and OO, Brown \& Roberts Addition; other lots in Haskell and Haskell County; and the gin and mill plants. D. C. Cogdell of Hood County was the successful bidder at $\$ 11,000$ on August 3, 1909. Two months later, he sold most of the property to the Western Cotton Oil \& Gin Company (also appears as Western Cotton Oil and Gin Company), a partnership composed of J. H. Chancellor of Bastrop County, J. C. Duke of Dallas County, Earl Cogdell of Haskell County, D. C. Cogdell of Hood County, and William Butterworth of Rock Island County, Illinois (Deed Record 46:304307; 60:125-127) (see Table 3). As a result, the Western Cotton Oil \& Gin Company became the new owner and operator of the gin plant on block 15 and the mill on outlot OO.

Other companies utterly failed during the same period. A streetcar system that began with great intentions in 1909 closed down in 1910 (Felker 1975:16), and the Haskell Light, Ice and Water Company defaulted on a note and its property sold at a trustee's sale on October 5, 1909 (The Haskell Free Press, October 2, 1909:2). The Haskell Creamery, organized in May 1910, soon closed (Sherrill 1965:139; Texas. Secretary of State 1910). A company formed by Haskell County citizens in September 1911 to construct or purchase cottonseed oil mills and gins dissolved fewer than 2 years later (Texas. Secretary of State 1911). Indeed, only one investor, Fred T. Sanders, seems to have successfully assumed risk. Sanders, who owned and operated the new gin on lots $3-4$, block 2 , Brown \& Roberts Addition, purchased lots 7-8, block 32, Haskell, and the gin plant on it from the estate of W. T. McDaniel on December 19, 1911 (Deed Record 60:339-341; Probate File No. 190) (see Table 3).

With improvement in weather and crop conditions in 1912, acquisition and construction activities resumed. The Farmers Union, whose warehouse previously had been near the railroad on lots 7-8, block 2, Brown \& Roberts Addition, moved its operations to lot 2, block 15, Haskell, where it erected a storehouse of corrugated iron on studs on property owned by George E. Courtney (Deed Record 49:277; 59:634; Sanborn Map Company 1913) (see Table 3, Figure 33). In July 1913, Sanders sold lots 7 8, block 32, Haskell, and the old W. T. McDaniel ([ca. 1907]-1911) and Fred T. Sanders (19111913) cotton gin plant (see Figure 33) to the Haskell District Union Gin Company (Deed Record 53:447). ${ }^{11}$ Two years later, with a large cotton crop of 31,281 bales ready for sale on a rising market (Sherrill 1965:121), the Haskell Bonded Warehouse Company purchased lots 12 and 7-8, block 15, Haskell, from George E. 

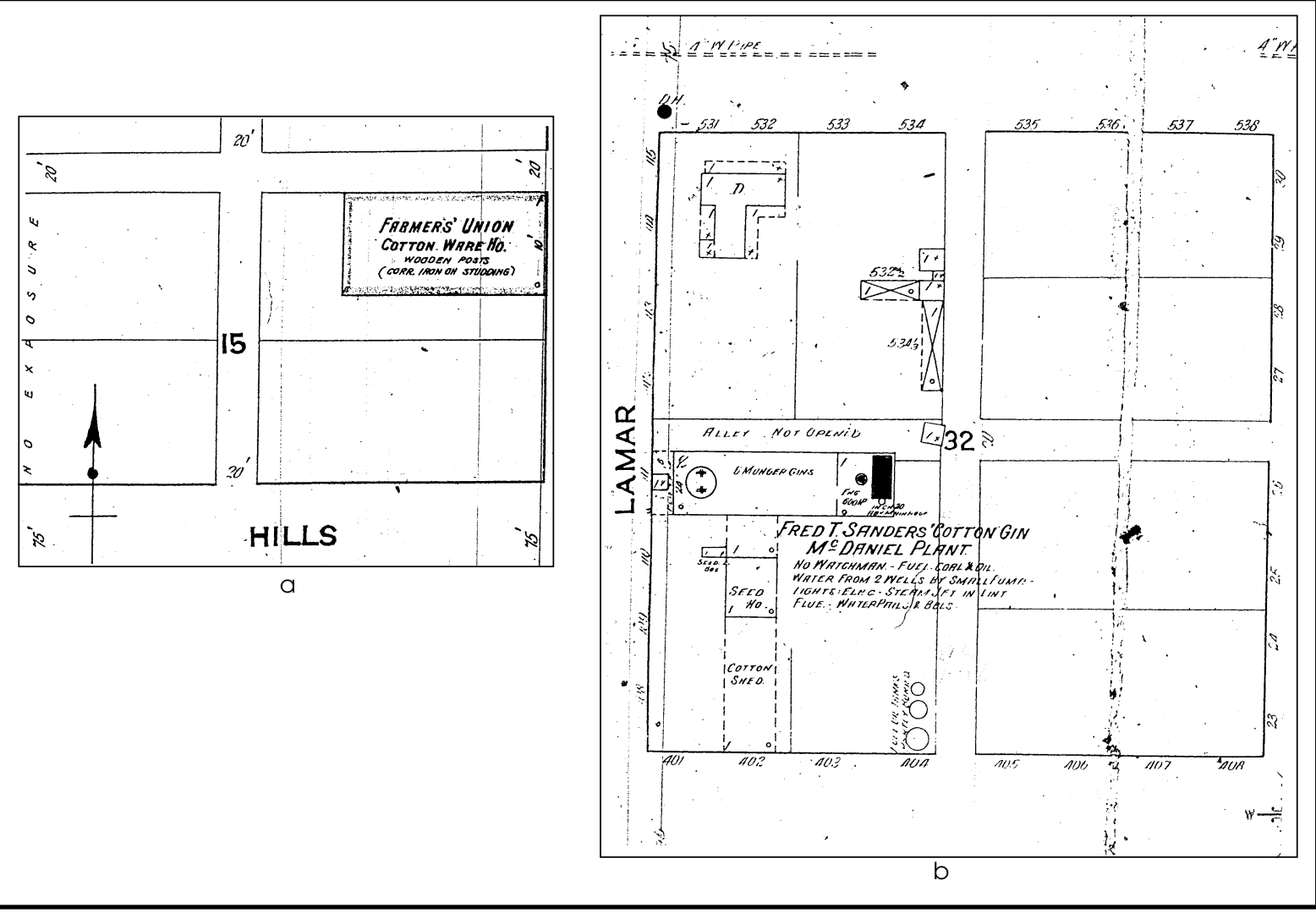

Figure 33. Sanborn maps. (a) Farmers Union Cotton Warehouse on block 15, Haskell; (b) McDaniel-Sanders Gin on block 32, Haskell. Sanders sold the plant for the Haskell District Union Gin Company in 1913.

and Louthene Courtney for $\$ 1,250$ in December 1915 (Deed Record 59:634). ${ }^{12}$ The newly formed company had incorporated only a week before, when it provided the state with a list of 82 subscribers from Haskell, Vontress, Weinert, and Rule. Most of the men were farmers, but community support was broad, and shareholders also included attorneys, the county and district clerks, the county tax collector, a laundry man,

11 The Haskell District Union Gin Company purchased the property from Sanders, but until 1923, the county assessor rendered the property under the name "Farmers Gin Co.," which is the name that appears on the Sanborn map of April 1921 and in a deed of February 9, 1923.

12 The relatively high price of the lots probably reflected the presence of the metal warehouse that had been operated on the property by the Farmers Union since at least 1913 (see previous note). a lumberman, ginners, a physician, a machinist, banks, a druggist, merchants, and a stockman. The purpose of the company was to "erect, purchase or lease and operate warehouses, buildings, elevators, storage tanks, silos and such other places of storage and security as may be necessary for the storage, grading, weighing and classification of cotton, wool, wheat, corn, rice, alfalfa, fruits, silage, and all other farm, orchard and ranch products." The corporation would have the authority to act as a warehouseman, charge for services, sell products in the market, and loan money (Texas. Secretary of State 1915b). Its members operated under the terms of an act passed by the Texas legislature in 1914 for the purpose of creating a regulated system of State-bonded warehouses and creating "a method of co-operative marketing for those engaged in the production of farm and ranch products" (Texas. Thirty-Third Legislature 1914:15-33). 
The economically favorable climate of 1912 1916 also encouraged other forms of investment. Morgan Jones, G. T. Scales, and W. G. Swenson organized to form the Haskell Ice and Light Company in 1915, which bought out the Haskell Ice, Light and Water Company (organized in 1906) and began to extend lines west to Rule and north toward Weinert (Broad \& Bonner [1915]; [Jones] 1915, [1915-1916]; Sanders and Sanders 1986:62; Sherrill 1965:122; Texas. Secretary of State 1915a). On a less positive note, a portion of the Western Cotton Oil \& Gin Company plant (see Figure 13) burned in 1916 at a purported loss of $\$ 75,000$. But the company was sufficiently prosperous to rebuild immediately (Sherrill 1965:85, 122). ${ }^{13}$

The beneficial weather of 1912-early 1916 changed abruptly during the latter part of 1916 (see Figure 7), but advancing prices helped offset short crops (Sherrill 1965:122). Perhaps banking on a return of the larger crops of recent years, two companies purchased property in Haskell and began construction of gins (see Table 3). Both companies were backed largely by nonlocal investors. The first of thesethe Haskell Electric Gin Company-was on lots $3-4$, block 66 , Haskell, land that had been purchased by J. M. Dunagin in March 1917 for a gin site (City of Haskell [Vol. 1]:275; Deed Record 58:583). About 2 weeks later, he sold the lots to Will Stith and R. W. Maxwell of Jones County (City of Haskell [Vol. 1]:275; Deed Record 122:598-599), and they erected a gin plant that they called the Haskell Electric Gin soon after (Assessors Abstracts of City Lots 1917-1918) (see Table 3, Figure 34). The second company-Harriss, Irby \& Vose-was owned by a partnership composed of Richard T. Harriss, Robert F. Irby, Alden H. Vose, and Mrs. William Bierce of Oklahoma County, Oklahoma; Baylis E. Harriss of Galveston; Raymond F. Harriss of New Orleans; and W. L. Harriss and R. M. Harriss of New York City. The partnership purchased lots 3-8, block 36, Brown \& Roberts Addition on April 11, 1917

${ }^{13}$ Sherrill states in one portion of his Haskell County history that the oil mill burned and in another that the seed house burned. A comparison of Sanborn plans from 1913 and 1921 suggests that the mill survived the fire, but that extensive rebuilding of a seed house and hull house occurred.
(Deed Record 83:420), and received a permit from the Haskell City Council to build a cotton gin on their property (City of Haskell [Vol. 1]:275) (see Table 3, Figure 20). But the record-breaking drought that began late in 1916 and persisted for 2 years was inexorable. By September 1917, Proctor \& Gamble's cotton crop report stated that the drought over central, western, and southwestern Texas was unbroken. The high, steady temperatures experienced just during July had brought about such a sharp deterioration that the crop was "practically a failure" (Proctor \& Gamble 1917:24). Twelve months later, the situation was no better. "Sharp deterioration" in the 1918 cotton crop continued, with the West Texas crop "practically a failure"; Central and East Texas were suffering as well (Proctor \& Gamble Co. 1918:38-39). In Haskell County, the meager crop of 12,844 bales ginned in 1917 (half the 1916 crop) dropped precipitously to 891 bales in 1918. Rainfall for the years 19161918 averaged 15.66 inches, with rainfall in 1917 totaling only 12.26 inches (Sherrill 1965:135136) (see Figure 7).

The effects of the weather and poor crop yields were devastating. The West Texas Utilities Company, a private corporation formed by Taylor County citizens to carry on the energy business, filed papers with the Secretary of State on November 7, 1917, but never issued stock, elected officers, or transacted business (Texas. Secretary of State 1917). Up to 50 percent of the farmers left Haskell County (Sherrill 1965:122), and the local newspaper frequently listed residents of the town of Haskell who moved elsewhere. George Courtney, who had operated a successful broom factory for 12 years, closed up and moved his family and factory to Fort Worth. S. A. Huskey, who had helped run the Haskell Bottling Works, moved to Amarillo (The Haskell Free Press, August 31, 1918:2). Dry goods businesses such as Hancock \& Co. ran ads stating their intention to remain in Haskell, but Hunt's announced that "On account of the extreme bad conditions of our country we were forced to move part of our goods to North Texas where we would have a better outlet for them." Nonetheless, Hunt's was "still in Haskell," contrary to rumors otherwise (The Haskell Free Press, August 31, 1918:2, 3). Hundreds of families moved to Wichita Falls, attracted by plentiful jobs in the booming oil fields. Those who stayed were urged by the town doctor to "Be 


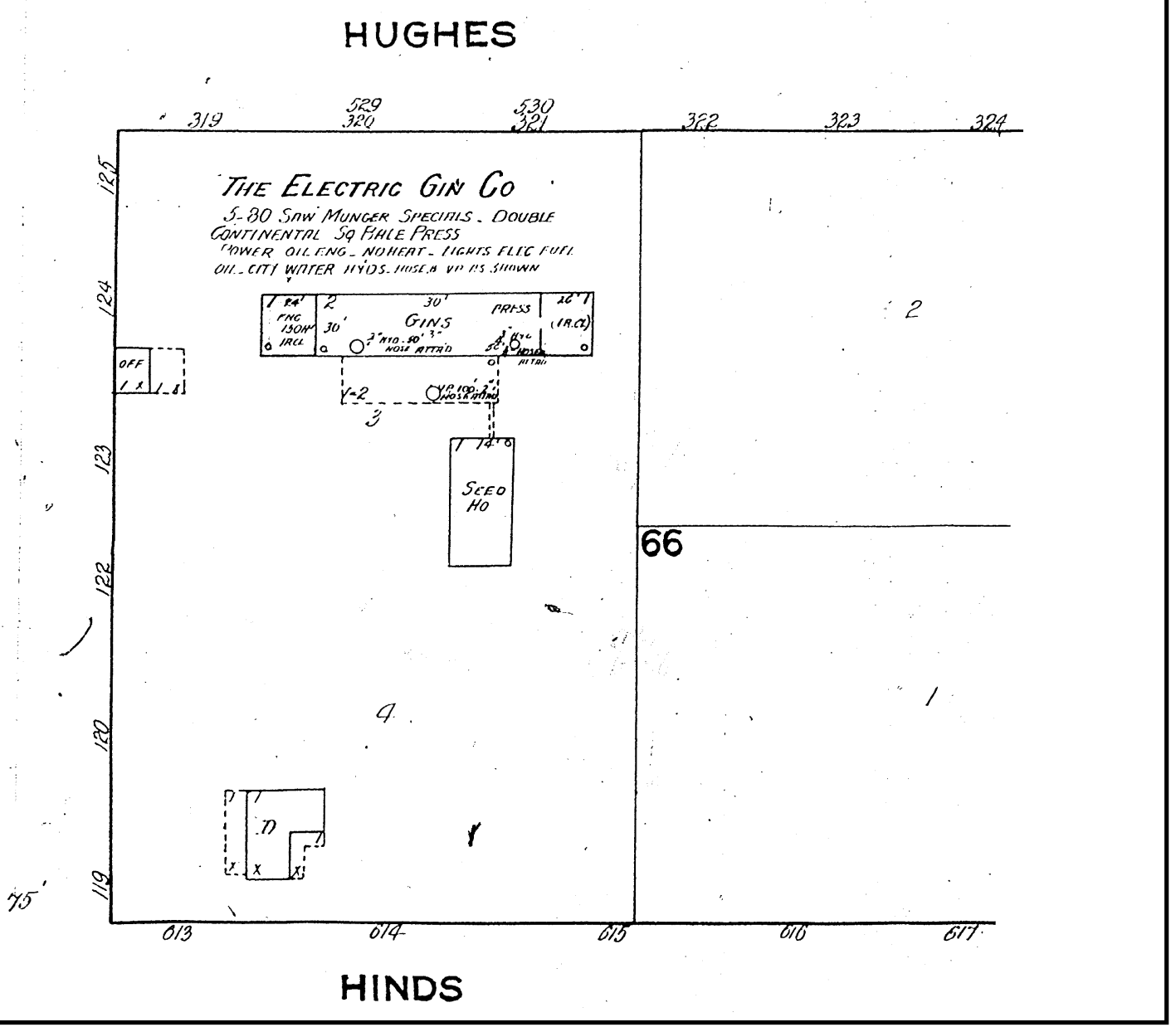

Figure 34. Sanborn map of the Electric Gin Company on block 66 .

faithful ... to your own county and people and e're long ... the drought will cease, [and] bountiful harvests, peace and contentment will be our reward" (The Haskell Free Press, September 7, 1918:3)

Dr. Woods's message was apocryphal. His letter was written during the last days of the drought, and a postscript published on September 7, 1918, carried the news that "splendid rains have fallen and the long drouth is broken" (The Haskell Free Press, September 8, 1918:3). Fortuitously, President Woodrow Wilson had already set aside $\$ 5$ million to extend aid to drought-stricken regions by advancing money to help farmers buy seed approved by the U.S. Department of Agriculture, which also would regulate the planting methods (The Haskell Free Press, September 7, 1918:4).
The farmers left in the county after the mass exodus of 1917-1918 planted intensively, not only during the last 4 months of 1918 , when rainfall averaged 2.61 inches per month or 61 percent of the total for 1918, but throughout 1919 as well, when rainfall totaled 35.93 inches (see Figure 7). Haskell resident R. E. Sherrill wrote:

In the fall of 1918, the largest grain crop ever planted in the county was planted by a small number of farmers; many farmers having moved away or were away in the army or navy. After two dry years, 1917 and 1918, when the land had produced no crops, no weeds, no grass, it needed no plowing. It was already prepared and ready for planting. Farmers got seed wheat from any possible 
source, and planted till oat planting time. They planted oats till feed planting time. They planted feed till cotton planting time. They harvested, threshed and marketed grain till time to gather feed. They gathered and marketed feed till cotton gathering time. They gathered and sold cotton till the winter 1919-20 was well nigh over, and till farmers in this country, with no cultivation, were worn out planting, gathering and marketing the largest crop per man they ever raised or probably ever will receive again. For there never before came together such crops and such prices, and probably never will come again. ... Deposits in the two Haskell Banks ran over a million dollars in November, 1919 (Sherrill 1965:128-129).

Reaction among investors who were involved with processing agricultural products was quick and presaged a decade-long flurry of company formation and construction of industrial plants as weather and markets remained generally beneficial and strong. As early as November 1918, the partnership of the Western Cotton Oil \& Gin Company filed incorporation documents. Investors were W. A. Earnest of Haskell, J. H. Chancellor of Smithville, D. C. Cogdell of Granberry, and J. C. Duke of Dallas, and they intended to purchase, operate, and maintain a cottonseed oil mill; to buy cottonseed, cottonseed cake, hulls, and meal; and to sell the products of the mill, which was on their property in Haskell adjacent to the Wichita Valley line (Texas. Secretary of State 1918) (see Table 3, Figure 20).

A drop in the price of cotton in 1920 brought a short-term financial setback (Sherrill 1965:129-130), but prosperity returned almost immediately, attracting men such as W. A. Duncan, who moved to Haskell in July 1922 and immediately formed the Duncan Gin Company with C. M. Francis of Jones County and M. L. Williams of Nolan County (Felker 1975:163; Texas. Secretary of State 1922). Eight months later, the Duncan Gin Company bought the Harriss, Irby \& Vose plant on lots 3-8, block 36, Brown \& Roberts Addition (Deed Record 93:624) (see Table 3, Figure 20).

The Farmers Gin Company, which operated the old McDaniel-Sanders gin plant on lots 7-8, block 32 , Haskell, lost its plant to fire on October 10, 1922, about the same time officers R. H. Darnell and J. A. Gilstrap applied to incorporate (City of Haskell [Vol. 1]:429). They then acquired lots 1-2, block 66, Haskell, two blocks west of the railroad and adjacent to the Electric Gin Company plant (Sanborn Map Company 1921), where they built a new gin (Assessors Abstracts of City Lots 1923-1924) (see Table 3, Figure 31 ). They sold the older gin property on block 32 to Charley McGregor on February 9, 1923 (Deed Record 101:170-171), but it is not clear if a new plant was on that property as well (see Table 3).

The town lost its oil mill in 1923 to a fire that was so costly that the owners were unable to rebuild. Thereafter, investors focused on gin and warehouse construction. In March 1924, the Haskell Bonded Warehouse Company voted to dissolve and sell its lots (1-2, 7-8, block 15, Haskell) and warehouse to E. B. Harrison of Jones County for $\$ 1,500$ (Deed Record 96:412413) (see Table 3, Figure 31). Harrison then hired Jones and Son Sheetmetal to build a gin plant, Jones's first in a business that eventually expanded to include gin cleaning services (Felker 1975:24-25). The plant was owned by Harrison and operated under his name and that of the plant manager, M. F. Spurlock, from 1924 to 1929 (Deed Record 175:339) (see Table 3). Harrison and his family then sold the property to the Farmer's Co-operative Society Number 2 of Haskell, which incorporated on August 26, 1929 (Texas. Secretary of State 1929b) under the terms of the Farmers' Co-Operative Society Act of $1925^{14}$ (Texas. Secretary of State 1925:659-661). The new corporation joined the Texas Farm Bureau Gin Company of Dallas County which had purchased block 32 , Brown \& Roberts Addition, on July 6, 1928, and erected a gin plant there soon after (Deed Record 116:496-497; Texas. Secretary of State 1928) (see Table 3, Figure 31). In the northern part of town, two blocks west of the railroad, the Farmers Co-operative Society Number One (also appears as "Farmers Cooperative Society

14 Spellings of works such as "Farmers," "Farmer's," "Co-operative," and "Co-Operative" reflect the variety of spellings used in corporation and other legal records. 
Number One," "Farmers Cooperative Society No. 1," and "Farmers Co-Operative Society No. 1) purchased 10.97 acres from C. W. and Lola Bell Shelley on June 24, 1929 (Deed Record 117:63$64)$. The society immediately erected a gin plant and furnished it with equipment from Continental, Murray, and Hardwicke-Etter Gin Companies (Chattel Mortgage Records on Realty 1:27) (see Table 3, Figure 31).

The strength of the 1920s agricultural economy in Haskell County was apparent in the new gin companies that acquired property in Haskell and built plants there. It also was evident in the willingness of gin operators to go into debt and invest in new equipment for their plants: between 1920 and 1929, the Haskell Electric Gin Company, Farmers Gin Company, Farmers Co-Operative Society No. 1, T. H. Wright, F. T. Sanders, Sanders \& Crawford, and E. B. Harrison took out substantial loans with the Continental, Murray, and Hardwicke-Etter Gin Companies; San Antonio Machinery \& Supply; and Tips Foundry \& Machine (Chattel Mortgage Records on Realty [1917-1969]). The prosperity of the 1920s also was evident in the formation of enterprises such as the Haskell Laundry Company (1923); Jones and Son Sheetmetal (1923), which diversified into the manufacture of gin cleaning machinery in 1926; Haskell County Fair Association (1924); Haskell Hotel Company, to which numerous gin and other companies subscribed (1925); and Haskell Amusement Company (1929) (Sherrill 1965:88, 139; Texas. Secretary of State 1923, 1924, 1925, 1929a). Finally, actual or planned improvements to local and county-wide infrastructure included extension of the Haskell-Weinert Road to Munday by the State Highway Department in 1926 (Sanders and Sanders 1986:5). In 1928, the Stamford \& Western Gas Company ran a line into town (Sherrill 1965:88). The Haskell National Bank entirely remodeled its building, the Haskell Telephone Company erected a new office building (Sherrill 1965:88), and the town promoted itself as an outstanding location for the new Texas Technological College after garnering the support of 16 other West Texas communities. Haskell offered the locating board a tract of 2,000 acres northwest of town and extolled the assets of the county, where "the corn and cotton lands of central and south Texas and the grain and forage-crop regions of North and West Texas, overlap each other" (Grissom et al. [ca. 1925]:n.p.).
Sanborn Map Company maps of Haskell in May 1931 reveal a town with seven operating gins (Haskell Electric Gin Company and Farmers Gin Company on block 66, Haskell; Duncan Gin Company on block 36, Brown \& Roberts Addition; Texas Cotton Growers Association on block $32,{ }^{15}$ Brown \& Roberts Addition; Farmers Co-operative Society No. 1 on block 95, Peter Allen Survey; Sanders \& Crawford on block 3, Brown \& Roberts Addition; and Farmer's Cooperative Society No. 2 on block 15, Haskell) (Figure 35) (see Table 3, Figures 27 and 31). In addition, there were five oil depots in the Brown \& Roberts Addition run by Humble Oil \& Refining (block 5), The Texas Company, Continental Oil, Magnolia Petroleum (block 12), and Gulf Refining (block 13) (Sanborn Map Company 1931).

Rainfall was average in 1931 but went well over the average in 1932, when Haskell County farmers refused to reduce cotton acreage voluntarily (see Figure 7). Production increased to ca. 82,000 bales, or 118 percent more than the 1931 crop, and the largest, by far, in the history of the county. Perhaps in response to the large harvest, L. B. Watson bought the Farmers Gin Company plant on lots 1-2, block 66, Haskell, on August 23, 1932 (Deed Record 123:168-169) (see Table 3). But size was not of long-term benefit because prices dropped precipitously to $4 \phi$ per pound in 1932 from $11.5 \%$ per pound at the beginning of the 1931 season (Sanders and Sanders 1986:107-108; Sherrill 1965:133). Weather remained favorable in 1933, when Watson sold his plant to A. H. Wair (Deed Record 124:399-400) (see Table 3), and cotton yields (50,369 bales) responded accordingly (Sherrill 1965:134). But the size of the crop dropped precipitously in 1934 to 11,916 bales, following unfavorable weather (Sherrill 1965:134). Yields rose again in 1935 to 41,717 bales with a guaranteed price of $12 \phi$ per pound thanks to an allotment and control plan, and nine individuals from Haskell, Weinert, Rule, and Sagerton were sufficiently encouraged by the economics to form the Haskell Cooperative Gin Company. Probably formed under the auspices of the Co-operative

${ }^{15}$ This was the plant owned by the Texas Farm Bureau Gin Company since 1928. That corporation changed its name to Texas Cotton Growers Gin Company in 1930 (Texas. Secretary of State 1928). 


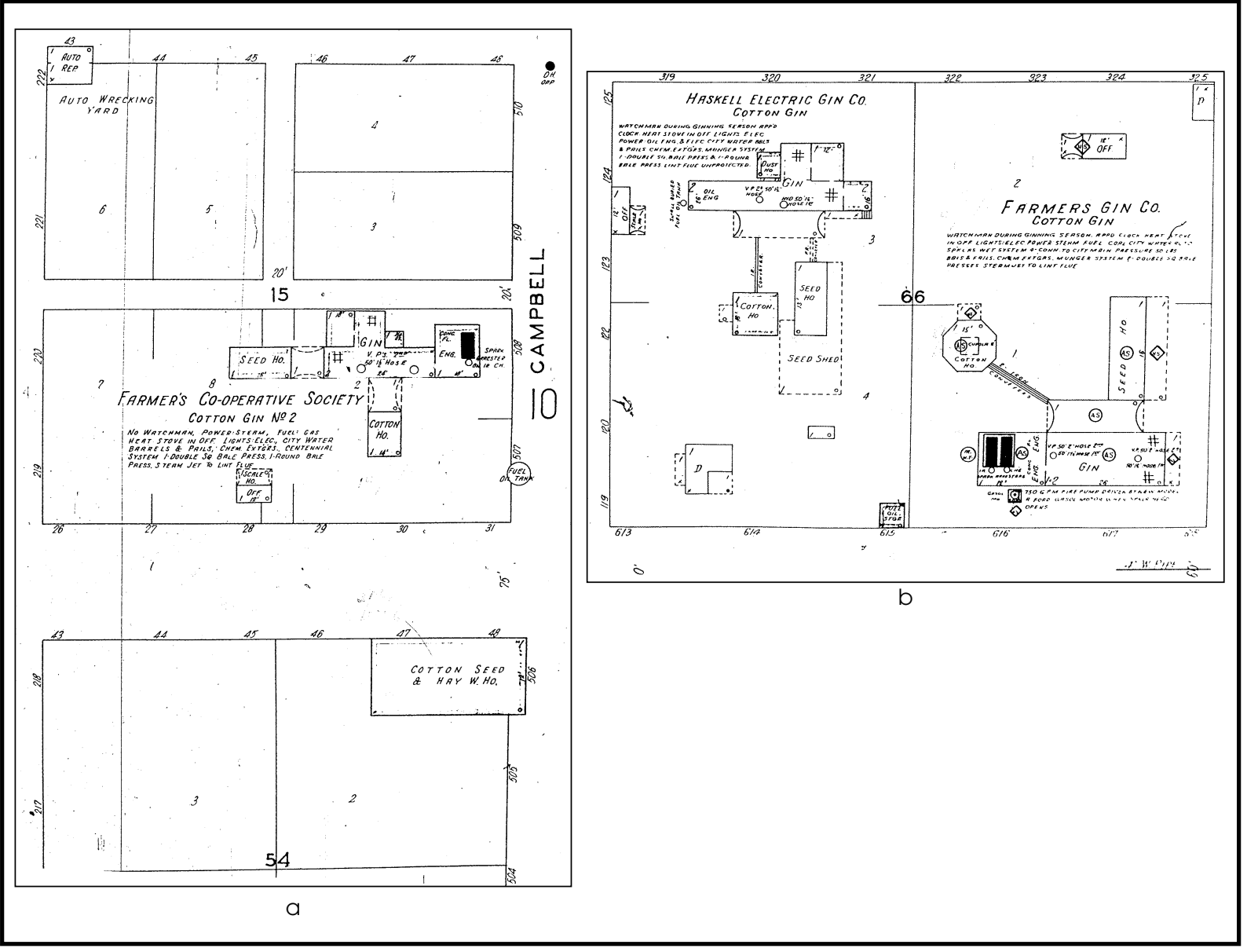

Figure 35. Sanborn maps. (a) Farmer's Co-Operative Society Gin No. 2 on block 15, Haskell; (b) The Farmers Gin Company and Haskell Electric Gin Company Cotton Gins on block 66, Haskell.

Marketing Act of the State of Texas (1925) amended in 1934 (Texas. Thirty-Third Legislature 1934:81-84), the corporation intended to market, manage, handle, and sell the agricultural products or byproducts of its members; to manufacture, sell, or supply members with machinery, equipment, or supplies; and to finance any of those activities (Texas. Secretary of State 1935). They purchased the Texas Farm Bureau Gin Company (Dallas) plant (lots 1-8, block 32, Brown \& Roberts Addition) on August 26, 1935 (Deed Record 129:247-249) and began operations there (see Table 3 ).

In 1936, six residents of Haskell and six from Rochester met and formed the Haskell County Farmer's Co-operative Gin Company of Haskell (Texas. Secretary of State 1936) under the auspices of the Co-operative Marketing Act, but there is no evidence in deed records that the co-operative purchased property to operate a gin. However, activity in the rest of the ginning and warehouse community was busy between 1937 and 1938: on December 6, 1937, D. H. Persons purchased lots 2-4, block 5, Brown \& Roberts Addition, from Clyde F. and Eula H. Elkins of Lubbock and constructed the Haskell Bonded Warehouse No. 1 soon after (Assessors Abstracts of City Lots 1938; Deed Record 164:20-21). In 1938, E. B. Harrison, whose plant was on lots 1-2 and 7-8, block 15, Haskell, changed operating managers from M. F. Spurlock to R. W. Herren (Deed Record 175:341); Producers Gin Company bought out the Haskell Electric Gin Company (lots 3-4, block 66, Haskell) (Deed Record 40:420-421), and Ed. ${ }^{16}$ F. Fouts bought lots 5-6, block 11, Brown \& Roberts 
Addition (Deed Record 140:449-450, 618), and constructed a cotton warehouse (see Table 3 ).

Simultaneously, companies invested heavily in new equipment in the 1930 s. These companies included the Farmers Cooperative Society No. 1, Farmers Gin Company, Inc., A. H. Wair, Harrison \& Gilstrap, Haskell Cooperative Gin Company, and Sanders \& Crawford. They contracted with the Continental, Gullette, Munger, and Cen-Tennial Cotton Gin Companies, and with John E. Mitchell Company of Dallas. Improvements included sprinkler systems, new gin stands, saws, and other ginning equipment (Chattel Mortgage Records on Realty [19171969]).

Haskell County lost approximately 10 percent of its population during the $1930 \mathrm{~s}$, but its cotton processing industries appear to have flourished, six of its seven cotton gins of 1931 having persisted, some under new ownership, until 1941 (Duncan Gin Company on block 36, Brown \& Roberts Addition; Haskell Cooperative Gin Company on block 32, Brown \& Roberts Addition; Farmers Co-Operative Society on

${ }^{16}$ The use of a period after "Ed" is intentional, as this is how it appears in the records. block 95, Peter Allen Survey; F. T. Sanders \& Son on block 3, Brown \& Roberts Addition; Wair \& Dulaney on block 66, Haskell; and Harrison and Herrin [also spelled Herren and Harren; also spelled Harrison \& Herrin] on block 15, Haskell) (Figure 36) (see Table 3, Figure 28). Cotton warehouse facilities had expanded from one in 1931 on block 54, Haskell, and probably associated with the Farmer's Cooperative Society Cotton Gin No. 2 on block 15, Haskell, to three facilities in 1941. The first of these, Haskell Bonded Warehouse No. 1 was on lots 2-4, block 5, Brown \& Roberts Addition. The other two were owned by Ed. F. Fouts who had expanded his large warehouses and cotton yards on block 11, Brown \& Roberts Addition, to block 4, Brown \& Roberts Addition, where he built a third warehouse and cotton yard (Sanborn Map Company 1941) (see Figure 28).

During the 1940s, the rate of population loss in Haskell County slowed to 7.8 percent, but the town's population grew by almost 26 percent. The rate of growth in Haskell then slowed until 1970, after which it decreased until, by 1990 , the population of the town was 3,362 and of the county, 6,820-less than half that of 1950 (Leffler 1996a:501-502; Tyler 1996b:500-501). By the mid-1980s, cotton had lost some of its

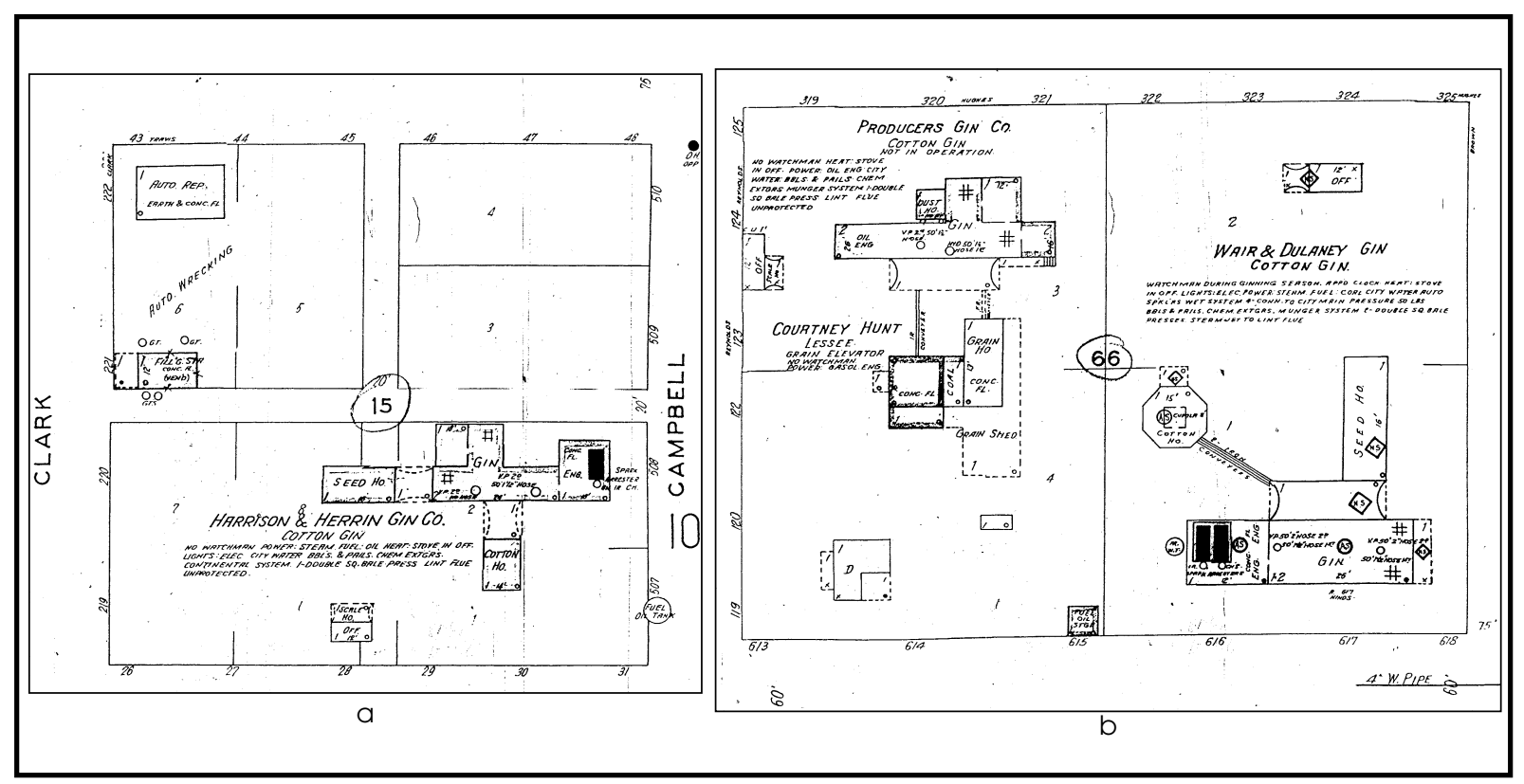

Figure 36. Sanborn maps. (a) Harrison and Herrin [Herran, Herren] Gin on block 15; (b) Wair \& Dulaney Gin on block 66. The Producer's plant which had been sold in 1940, was not in operation the following year. 
popularity as prices fell and expenses rose (Sanders and Sanders 1986:111), and a tenacious drought in the 1990s drove many agriculturists to turn from cotton to livestock production.

Investment in cotton-related industries slowed as well, despite the appearance of mechanical cotton harvesters in the 1950s and an increasing tendency toward fewer, but much larger, farms (Sanders and Sanders 1986:106, $110)$. In the 1940s, Fouts expanded his warehouse operation, but one of the old ginning companies simply changed names-Harrison \& Herrin to Harrison \& Gilstrap in 1940-and then sold out its plant on block 15, Haskell, to Buford Cox in 1952; Cox sold out to W. E. Wooten 2 years later (Deed Record 175:341; 225:348; 238:59-60). Charlie Motz Jr. and Mrs. M. A. Curtis bought the old Producers Gin Company plant on block 66, Haskell, in 1940, and resold it to Ernest Griffith in 1942; Griffith appears to have disassembled the plant shortly thereafter (Deed Record 149:24-25; 153:462; 154:122-123, 216-217; 156:418; 178:96-97). The Rule-Jayton Cotton Oil Company, which owned much of the property formerly owned by Western Cotton Oil \& Gin Company but never rebuilt the burned plant, also owned the gin plant on blocks 2-3, Brown \& Roberts Addition, that it had purchased from Fred Sanders and his son in 1947. However, operation had ceased by 1958, when Rule-Jayton sold the property to the Market Poultry \& Egg Company (Deed Record 178:457-458, 523-524; 273:1-2). By 1949 , operating gins included the Duncan Gin (block 36, Brown \& Roberts Addition), Haskell Cooperative Gin (block 32, Brown \& Roberts Addition), and the Harrison \& Herrin Gin (block 15, Haskell) (Sanborn Map Company 1949) (Figure 37) (see Table 3). By the 1970s, the old Duncan Gin had been sold to the K-G Gin Company, which later went out of business. In 2002 , the only historic gin company still in operation of the many that had been adjacent to the Wichita Valley Railway line was the Haskell Cooperative Gin Company.

In summary, cotton production began in Haskell County in 1887, when George Baggett sold the first bale. The first gin in Haskell was erected in 1889 east of the square by J. L. Jones and N. C. Smith. Cotton production increased steadily until the early 1900 s, when a combination of boll weevil-induced crop failures in the Blackland Prairie region of Texas and heavy promotion of the North Central Plains by newspapers and real estate agents brought a flood of immigrants who were experienced in cotton culture. Their arrival and the ensuing increase in cotton production did much to convince officers of the Wichita Valley Railway to extend the rail line south from Seymour in Baylor County.

Completion of the Wichita Valley Railroad in 1906 provided impetus to local and outside investors in cotton processing plants, and two cotton warehouses and three cotton gins began or continued operation between 1906 and 1908 . While one new gin plant was erected west of the courthouse and the Haskell Oil Mill Company continued to use an older mill south of the courthouse, the balance of the plants were adjacent or near the new Wichita Valley Railroad line.

Sufficient rain and large crops between 1911 and 1915 were accompanied by another round of buying and selling plants and of new construction and expansion of existing plants. Due to drought, activity then ceased, for the most part, until the 1920s, when numerous new companies and farmers cooperatives either bought old gin plants or built new ones. Contrary to conventional wisdom, which has represented the 1930s as a decade of depression and inactivity, Haskell experienced a continuation of company formation and the use of ginning plants as Haskell and surrounding counties enjoyed large cotton harvests in 1932-1933 and 1935. Indeed, stagnation does not appear to have occurred until the 1940 s, with significant decline in the number of cotton processing facilities occurring during the drought years of the $1950 \mathrm{~s}$.

Three properties associated with the cotton industry that are adjacent to the Wichita Valley Railroad line in Haskell still survive; two of them are in operation:

1. Block 32, Brown \& Roberts Addition-Texas Farm Bureau Gin (1928-1935), Haskell Cooperative Gin (1935-present): J. T. Orr (Dallas), W. W. Pitts (Wills Point), Lynn Stokes (Ballinger), M. S. Hudson (Hale Center) and E. M. Baldwin (Colorado, Texas) associated on April 10, 1928, for the purposes of forming a ginning and storage corporation to be called Texas Farm Bureau Gin Company. The principal place of business was Dallas, the life 


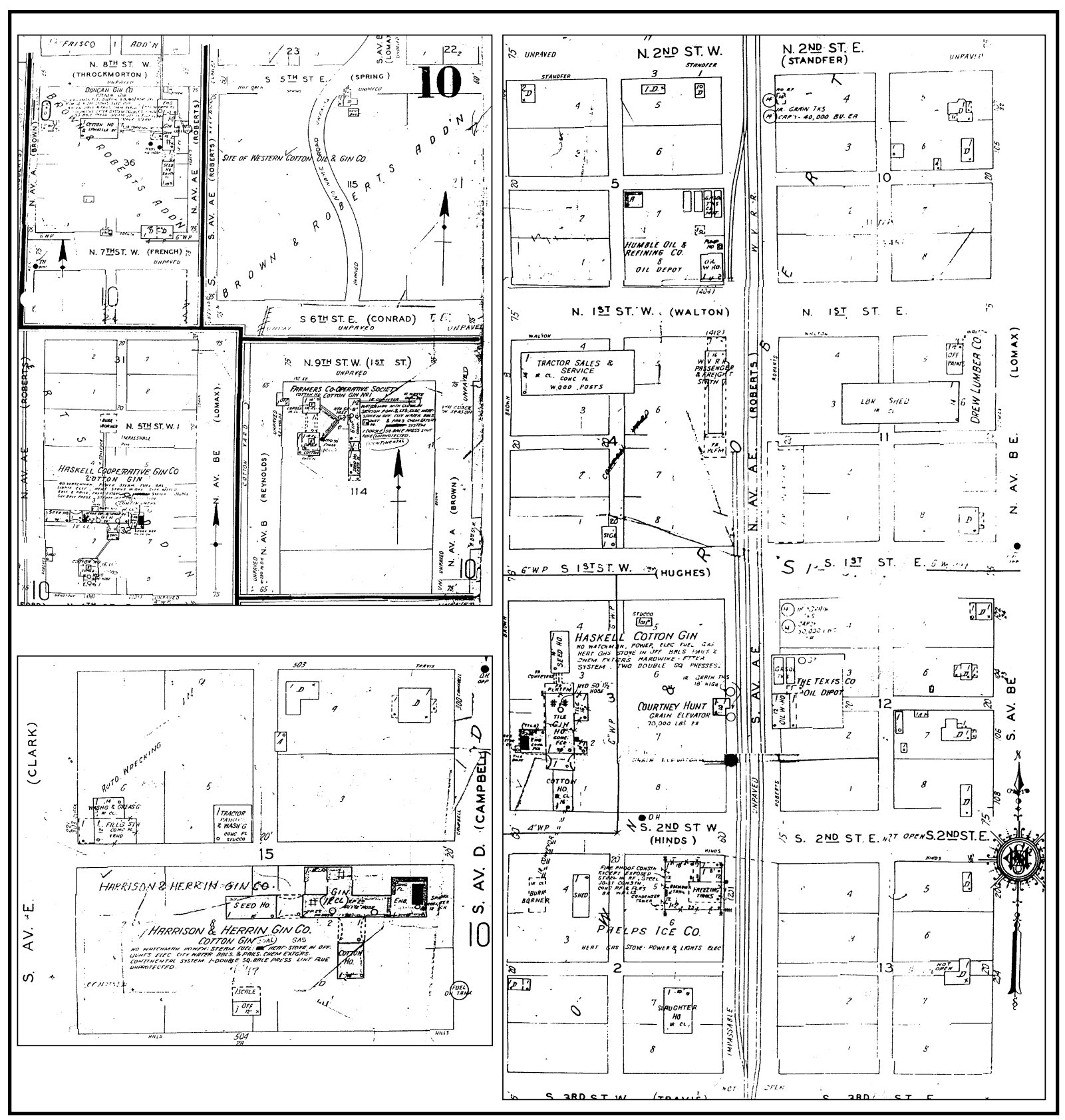

Figure 37. Sanborn maps of cotton processing facilities in Haskell, 1949.

of the corporation was 50 years, and the capital stock was $\$ 200,000$. On July 6,1928 , the company bought lots 1-2 and 7-8, block 32, Brown \& Roberts Addition, from J. M. and Irene Davis and lots $3-6$, block 32, from Catherine E. and Mart Clifton (Deed Record 116:496-497) and built a gin plant soon thereafter.
On May 6, 1930, the stockholders voted to change the name of the company to Texas Cotton Growers Gin Company and increase the capital stock to $\$ 1,000,000$ (Texas. Secretary of State 1928). One year later, the company's facility in Haskell consisted of a gin, seed house, office, cotton house, and shed. It operated 
using a Munger system and had one double-square bale press (Sanborn Map Company 1931).

On August 26, 1935, the Texas Cotton Growers Gin Company sold its plant to the Haskell Cooperative Gin Company, a corporation formed on May 13, 1935, by A. L. Adams, W. F. Wells, J. F. Simmons, Willis Harrell, J. C. Lewellen, and F. A. Linville of Haskell; G. L. Walker of Weinert; J. S. Hays of Rule; and R. T. Jeter of Sagerton. The term of the corporation was to be 50 years, and capital stock was $\$ 50,000$ (Texas. Secretary of State 1935). The cooperative appears to have made few, if any, changes to the plant by 1941 (Sanborn Map Company 1941). By 1949 the cooperative had added a conveyor north of the gin plant, which led to a burr burner in the apparently abandoned right of way of North $5^{\text {th }}$ Street (Sanborn Map Company 1949).

The original gin building is intact, as is the burr burner, and the plant still operates with ContinentalMurray equipment. Since 1949, however, there have been numerous alterations and additions. A seed house on the east side of the gin building has been removed and replaced with an open seed pad. A row of cyclones, to handle trash from the gin, has been installed on the north side of the gin building between it and the burr house. The cotton house south of the gin has been replaced by a large, multicomponent metal building that houses a module feeder, separator, and storage or warehouse space. These last additions were constructed after 1991 , when the cooperative also installed a new Continental press. Construction was done by Terry Joe Brigaman, a local contractor (Jones 2002).

Since 1991, there have been only 2 good years for the local cot- ton industry, and the cooperative has had trouble getting enough cotton. Crops of ca. 15,000 bales in 1992 and 1997 have been offset by crops averaging 7,000 bales or less from 1993 to $1996,2,300$ bales in 1998, and 396 bales in 1999. In addition, local competition has increased in recent years due to the reopening and modernization of the ca. 1929 Farmers Cooperative Society Number One Gin plant on Block 95, Peter Allen Survey (Jones 2002).

2. Block 36, Brown \& Roberts Addition-Harriss, Irby \& Vose Gin (1917-1923), Duncan Gin (19231970s), K-G Gin Company (Jerry Don Klose) (1970s-1990s): On April 11, 1917, a partnership composed of Richard T. Harriss, Robert F. Irby, Alden H. Vose, and Mrs. William Bierce of Oklahoma County, Oklahoma; Baylis E. Harriss of Galveston; Raymond F. Harriss of New Orleans; and W. L. Harriss and R. M. Harriss of New York City, purchased lots 3-8, block 36 , Brown \& Roberts Addition, from Edward W. and Daisy Hill of Robertson County, Texas, for $\$ 500$ (Deed Record 83:420). The partnership constructed a gin plant soon after (Assessors Abstracts of City Lots 1918) and operated it despite the ravages of the 1917-1918 drought. In 1921, the plant consisted of a T-shaped facility. The southernmost element was a seed house, which was separated from the press and gin building on the north by a concrete platform. The press and gin room, containing one double-square bale press and four 80-saw Munger specials, was adjacent to an offset, iron-clad engine room. A cotton house formed the base of the $\mathrm{T}$ and centered on the press and gin room. Other buildings on the site included a roofless coal bin, wagon shed, and office (Sanborn Map Company 1921).

On March 27, 1923, Harriss, 
Irby and Vose sold lots 3-8, block 36, Brown \& Roberts Addition, to the Duncan Gin Company for $\$ 14,000$ (Deed Record 93:627). The company was formed by W. A. Duncan of Haskell County, C. M. Francis of Jones County, and M. L. Williams of Nolan County, who received a charter in July 1922 for the purposes of constructing, purchasing, and maintaining cotton gins (Texas. Secretary of State 1922). On February 5, 1924 , the company purchased the balance of block 36 (lots 1-2) at a tax sale (Deed Record 96:185).

Duncan's gin plant retained the 1921 configuration through 1931 (Sanborn Map Company 1931). By 1941, Duncan had added a room to the north end of the office and a collector to the east side of the gin room (Sanborn Map Company 1941). A more-major change occurred by 1949 , with the removal of the cotton house to a position west of its earlier location and the addition of a burr burner on the block north of the plant (Sanborn 1949). By the late $1970 \mathrm{~s}$, the plant had been sold to K-G Gin Company (Jones 2002). Either the Duncan family or the gin company removed the detached cotton house and engine room, leaving a two-story, wood-frame building clad in corrugated metal. The roof retained its gable configuration, and windows were six-light industrial metal awning units. The office and scale house was a wood-frame, gable-roof building clad in asbestos shingles and having a shed-roof addition on the west side. A concrete apron adjacent to the building included scales and other equipment.

3. A part (31.16 acres) of outlot 100 , Brown \& Roberts AdditionHaskell County Warehouse and Compress Company, Inc. (19591989), Texas Compress and Warehouse Corporation (1989-present):
This warehouse complex is on 31.16 acres in outlot 100 , Brown \& Roberts Addition, on the west side of and adjacent to the Wichita Valley Railroad line. The property was owned in 1920 by M. H. and C. C. Gilliam, who sold it to F. A. and Nora Linville on January 19, 1920, for $\$ 2,325$ (Deed Record 111:501-502). The Linvilles' property was valued at an unimproved rate by the county. However, F. A. Linville was one of the incorporators of the Haskell Cooperative Gin Company in 1935 (Texas. Secretary of State 1935), and a local informant (Jones 2002) believed that the cooperative had stored cotton at the 31.16-acre site "almost since it began."

On May 22, 1959, F. A. Linville, now a widower, sold the property to R. W. Herren for $\$ 9,318.75$ (Deed Record 274:459-460). Two weeks later, Herren sold the property to the Haskell County Warehouse and Compress Company, Inc. (Deed Record 275:400-401), which had incorporated on May 20, 1959 (Texas. Secretary of State 1959). The five-man board of directors included Herren, who had run E. B. Harrison's gin on block 15 in Haskell from 1938 to 1940 (Deed Record 175:341), and Buford Cox, who had purchased Harrison's gin in 1952 (Deed Record 225:348). The company constructed improvements on the 31.16 acres, the value of which increased from $\$ 12,000$ in 1972 to $\$ 19,500$ in 1976 , and $\$ 78,000$ in 1981 (Assessors Abstracts of City Lots 1972-1981).

On January 19, 1989, the shareholders of the Haskell County Warehouse and Compress Company voted to dissolve the company (Texas. Secretary of State 1959) and on April 18 , they sold the 31.16 acres and six lots in block 43, Frisco Addition, Haskell, to the Texas Compress and Warehouse Corporation for $\$ 175,000$ 
(Deed Record 445:186-187). The Texas Compress and Warehouse Corporation, formed in February 1984 by A. C. Culpepper, Annette D. Culpepper, A. W. Culpepper, and J. R. Culpepper, all of Kennett, Missouri, initially used an agent in Seymour (Texas. Secretary of State 1984). In 2002 , the complex was operated by R. Culpepper of Stamford (Jones 2002).

The plant consists of a threebuilding warehouse complex, loading docks, and several small offices, sheds, and outbuildings. The warehouses are one-story, gable-roof buildings clad in corrugated metal siding and roofing. Sliding metalclad doors are at the gable ends of each warehouse. A continuous linear loading dock constructed of concrete extends along the east side of each warehouse adjacent to the railroad. East of the warehouse are four buildings, including an office and scale house, garage, and two sheds. The office and scale house is a gableroof, wood-frame building with a corrugated metal roof and stuccoed exterior walls. Windows are oneover-one wood sash, and doors are wood panel types. The sheds are wood frame and metal clad. ${ }^{17}$

${ }^{17}$ Architectural descriptions of the cotton-related properties are taken from materials prepared by Joe C. Freeman for the Texas Department of Transportation. 



\section{BIBLIOGRAPHY}

Abilene Reporter, The

$1884 \quad$ Illustrated Northwest Texas; or the Third Annual Special Edition of the Abilene Reporter. The Abilene Reporter, Abilene, Texas.

Description of Abilene, Taylor County, and surrounding counties in the 1880s; promotional brochure published during the height of the livestock industry and beginning of crop cultivation.

A. H. Belo \& Company

1912 Texas Almanac and State Industrial Guide, 1912. A. H. Belo \& Company, [Dallas].

Helpful descriptions of counties and towns along the present-day Highway 277 route.

1926

The Texas Almanac and State Industrial Guide. A. H. Belo \& Company, Dallas.

Excellent statistics documenting petroleum production in Texas by fields, 1896-1925.

Anderson, H. Allen

1996a Abilene and Northern Railway. In The New Handbook of Texas, vol. 1, edited by Ron Tyler, p. 10.

The Texas State Historical Association, Austin.

Helpful general treatment of the subject that provides a broad overview and bibliographic references for the reader interested in more in-depth treatments. Not always a reliable source of information, but good for general data. ${ }^{18}$

1996b SMS Ranches. In The New Handbook of Texas, vol. 5, edited by Ron Tyler, pp. 738-739. The Texas State Historical Association, Austin.

1996c Waggoner Ranch. In The New Handbook of Texas, vol. 6, edited by Ron Tyler, pp. 785-786. The Texas State Historical Association, Austin.

Anderson, H. Allen, and John Leffler

1996 Knox County. In The New Handbook of Texas, vol. 3, edited by Ron Tyler, pp. 1,149-1,150. The Texas State Historical Association, Austin.

Anonymous

[1909?] Report on conditions in the Wichita Valley, [April 1909?]. File 50077, Box 205, Fort Worth \& Denver Railway Collection, Southwest Collection, Texas Tech University, Lubbock.

With Sherrill (1965), the documents within the Fort Worth \& Denver Railway Collection are the most fundamental sources for understanding the relationships among weather, regional agricultural trends, economic development, human behavior, and railroad construction. ${ }^{19}$

1911 Report on crop conditions, May 16, 1911. File 50232, Box 206, Fort Worth \& Denver Railway Collection, Southwest Collection, Texas Tech University, Lubbock.

1915 Memorandum of Crop Conditions, May 29, 1915. File 50232, Box 206, Fort Worth \& Denver Railway Collection, Southwest Collection, Texas Tech University, Lubbock.

Archer County Family History Committee, The

1986 Archer County Family History: Shortgrass Saga. Archer County Family History Committee, n.p.

Genealogies and family histories of Archer County residents.

${ }^{18}$ This comment generally pertains to entries from the Fort Worth \& Denver Railway Collection.

${ }^{19}$ This comment generally pertains to entries from the Grenville M. Dodge Papers. 
Aynesworth, Mrs. Jos. H. (arranger)

1942 Jos. H. Aynesworth: a Texan: Life and Writings. Childress County News, Childress, Texas. Description of Joseph H. Aynesworth, a Wichita Falls lawyer who represented oil interests. Includes his history of the Wichita County area, reprinted from the Wichita Falls Daily Times.

Baker, V. E. 1909

Letter from V. E. Baker, Stamford, Texas, April 23, 1909, to D. B. Keeler, Ft. Worth, Texas. File 50421, Box 208, Fort Worth \& Denver Railway Collection, Southwest Collection, Texas Tech University, Lubbock.

Baker, W. A. 1909

Letter from W. A. Baker, Munday, Texas, February 23, 1909, to O. E. Maer, Wichita Falls, Texas. File 50044, Box 205, Fort Worth \& Denver Railway Collection, Southwest Collection, Texas Tech University, Lubbock.

Baylor County Historical Society

1972 Salt Pork to Sirloin: The History of Baylor County, Texas[,] from 1879 to 1930. Nortex Offset Publications, Inc., [Quanah].

General overview history of Baylor County with more in-depth histories of businesses, schools, social organizations, and founding families. Excellent photographs of early gins, compresses, mills, ice houses, bottling companies, and oil and gas properties.

Billingsley, William C.

1996 Fort Worth and Denver Railway. In The New Handbook of Texas, vol. 2, edited by Ron Tyler, p. 1,125. The Texas State Historical Association, Austin.

Bomar, D. T.

1907

Letter from D. T. Bomar, on Wichita Valley Railway, Stamford, Texas, February 12, 1907, to W. A. Baker, Munday, Texas. File 50044, Box 205, Fort Worth \& Denver Railway Collection, Southwest Collection, Texas Tech University, Lubbock.

Britton, Sarah Ann

1955 The Early History of Baylor County. The Story Book Press, Dallas.

Personal account of Baylor County history that includes reprinted material.

Broad \& Bomar

[1915] Letter from Broad \& Bomar, [Fort Worth, Texas], [1915], to Morgan Jones, Abilene, Texas. Morgan Jones Collection, Financial documents, 1902-1944, Microfilm J78C, Reel 1, p. 230. The Southwest Collection, Texas Tech University, Lubbock.

Financial documents in the Morgan Jones Collection detail his involvement in businesses along the route of the Wichita Valley Railway and Railroad.

Caffey, David L.

1981 The Old Home Place: Farming on the West Texas Frontier. Eakin Press, Burnet, Texas. History of the Caffey family, farmers south of Anson, Jones County. Does not include information of particular use to the region.

Casey, Clifford B.

1974 A Baker's Dozen. We Were Thirteen: The Caseys of Tuscola, Taylor County, Texas. Pioneer Book Publishers, Inc., Seagraves.

Family and community history in Taylor County, ca. 1870s-1974 with emphasis on the 1899-1974 period.

Central West Texas Dry Farming Congress

1911 Official Program of the Central West Texas Dry Farming Congress. N.p., Abilene, Texas. File 50627, Box 209, Fort Worth \& Denver Railway Collection, Southwest Collection, Texas Tech University, Lubbock. 
The program illuminates, through the titles of specific programs, the interests and concerns of farmers following an early twentieth-century drought.

Clack, Mary Hampton

1979 Early Days in West Texas. In Pioneer Days. . . Two Views. Zachry Associates Inc., Abilene, Texas.

Interesting reminiscence of rural Taylor County life during the earliest days of settlement south of present-day Abilene, Texas.

Clary, Annie Vaughan

1956 The Pioneer Life. American Guild Press, Dallas.

General treatment of Haskell County history that borrows heavily from Sherrill (1975).

Cogdell, Earl

1912

Letter from Earl Cogdell, Haskell, Texas, March 28, 1912, to D. B. Keeler, Fort Worth, Texas. File 50816, Box 211, Fort Worth \& Denver Railway Collection, Southwest Collection, Texas Tech University, Lubbock.

Cotter, G. F. 1908

Letter from G. F. Cotter, Fort Worth, [Texas], February 10, 1908, to D. B. Keeler, Fort Worth, Texas. File 50297, Box 207, Fort Worth \& Denver Railway Collection, Southwest Collection, Texas Tech University, Lubbock.

1909 Letter from G. F. Cotter, At Haskell, Texas, August 25, 1909, to D. B. Keeler, Fort Worth, Texas. File 50458, Box 208, Fort Worth \& Denver Railway Collection, Southwest Collection, Texas Tech University, Lubbock.

Cravens, Chris 1996

Wichita Valley Railway. In The New Handbook of Texas, vol. 6, edited by Ron Tyler, p. 960. The Texas State Historical Association, Austin.

Davis, Charles G.

1996 Mabelle, Texas. In The New Handbook of Texas, vol. 4, edited by Ron Tyler, p. 359. The Texas State Historical Association, Austin.

Dodge, C. P. 1907

Letter from C. P. Dodge, Beaumont, Texas, September 9, 1907, to Morgan Jones, Fort Worth, Texas. File 50264, Box 207, Fort Worth \& Denver Railway Collection, Southwest Collection, Texas Tech University, Lubbock.

Dodge, G. M. 1905

Letter from G. M. Dodge, New York City, August 18, 1905, to H. Walters, New York City. Grenville M. Dodge Papers, Volume 18, State Historical Society of Iowa - Des Moines. The Grenville M. Dodge Papers are an excellent source of information about the involvement of the Fort Worth \& Denver City and Wichita Valley lines in the project area. Political and economic concerns are clearly identified..$^{20}$

Downs, Fane 1996

Abilene, Texas. In The New Handbook of Texas, vol. 1, edited by Ron Tyler, pp. 8-9. The Texas State Historical Association, Austin.

Duff, Katharyn 1970

Abilene. .. On Catclaw Creek. The Reporter Publishing Co., Abilene, Texas.

Excellent overview of the pre-1870s history of Taylor County and the general region, settlement near Buffalo Gap, construction of the Texas \& Pacific Railroad and its impact on

${ }^{20}$ This comment generally pertains to entries from The New Handbook of Texas. 
settlement patterns and regional economics, and economic trends in twentieth-century Taylor County as the oil and gas industries become more important.

Felker, Rex A.

1975

Haskell: Haskell County and Its Pioneers. Nortex Press, Quanah, Texas.

Good bi-centennial history of Haskell County and its communities that helps bring Sherrill (1975) forward to the 1970s. Information about pioneer families and businesses is particularly helpful.

Gausewitz, H. A.

1917 Letter from H. A. Gausewitz, Fort Worth, [Texas], March 15, 1917, to D. B. Keeler, Henrietta, Texas. File 50085, Box 205, Fort Worth \& Denver Railway Collection, Southwest Collection, Texas Tech University, Lubbock.

Gilbert, C. E. 1884

Illustrated Northwest Texas, or the Third Annual Special Edition of the Abilene Reporter. C. E. Gilbert, Abilene, Texas.

See Abilene Reporter, The.

Glisson, A. A. 1908

Letter from A. A. Glisson, Fort Worth, Texas, March 2, 1908, to Homer D. Wade, Stamford, Texas. File 50022, Box 205, Fort Worth \& Denver Railway Collection, Southwest Collection, Texas Tech University, Lubbock.

1911 Letter from A. A. Glisson, Fort Worth, Texas, August 19, 1911, to D. B. Keeler, [Fort Worth, Texas]. File 50748, Box 210, Fort Worth \& Denver Railway Collection, Southwest Collection, Texas Tech University, Lubbock.

Goree, R. D. [1890s]

Texas Supremacy Over All States. Clarke \& Courts, Stationers, Galveston.

Brochure designed to encourage immigration to Knox County in the early twentieth century.

Graves, Lawrence L.

1996 Baylor County. In The New Handbook of Texas, vol. 1, edited by Ron Tyler, pp. 426-428. The Texas State Historical Association, Austin.

Gray, Mrs. R. D. 1963

Early Days in Knox County. Carlton Press, New York.

County history focusing on local communities and including vignettes of early settlers and residents of the county from about 1880 to the mid-twentieth century.

Grissom, Hardy, O. E. Patterson, R. E. Sherrill, B. Cox, and R. C. Couch [?]

[ca. 1925] Haskell, the Strategic Location for the Texas Technological College, N.p., n.p.

A snapshot of Haskell in the mid-1920s, when the town hoped to be selected as the location of the new state technological college.

Hart, Brian 1996

Wichita County. In The New Handbook of Texas, vol. 6, edited by Ron Tyler, pp. 952-953. The Texas State Historical Association, Austin.

Haskell, City of

City Council Minutes

Excellent source of information about city policies vis-à-vis businesses in Haskell; building permits are recorded occasionally.

Haskell County

Assessors Abstracts of City Lots

Chattel Mortgage Records on Realty 
Deed Records

Deed of Trust Records

Materialsman Liens

Probate Files

County records are the primary and essential sources of information about property ownership and construction of improvements.

[Haskell County (Tex.)], Program Building Committee

$1970 \quad$ Long Range County Program. N.p., n.p.

General information about Haskell County history with specific statistics about population trends; a snapshot of Haskell and Haskell County in 1970.

Haskell Free Press, The

Excellent source of information about events that were important to the development of the community.

Hastings, F. S.

1911

Letter from F. S. Hastings, [Stamford, Texas], May 29, 1911, to S. M. Swenson \& Sons, New York City. File 50232, Box 206, Fort Worth \& Denver Railway Collection, Southwest Collection, Texas Tech University, Lubbock.

1914 Letter from F. S. Hastings, Stamford, Texas, August 21, 1914, to S. M. Swenson \& Sons, New York City. File 50232, Box 206, Fort Worth \& Denver Railway Collection, Southwest Collection, Texas Tech University, Lubbock.

1915 Letter from F. S. Hastings, Stamford, Texas, February 26, 1915, to S. M. Swenson \& Sons, New York City. File 50232, Box 206, Fort Worth \& Denver Railway Collection, Southwest Collection, Texas Tech University, Lubbock.

Hastings, Frank S.

1912 Letter from Frank S. Hastings, Stamford, Texas, September 21, 1912, to S. M. Swenson \& Sons, New York City. File 50232, Box 206, Fort Worth \& Denver Railway Collection, Southwest Collection, Texas Tech University, Lubbock.

Hendrickson, Kenneth E., Jr.

1996 Wichita Falls, Texas. In The New Handbook of Texas, vol. 6, edited by Ron Tyler, pp. 955-956. The Texas State Historical Association, Austin.

Hipple, Belle Maxine Burnison (compiler and editor)

$1972 \quad$ Legacy of the Knox County Prairie: A History of Gillespie-Thorpe Communities. San Felipe Press, Austin.

Brief county-level treatment; focus is on the Gillespie and Thorp communities.

Hunt, William R.

1996 Seymour, Texas. In The New Handbook of Texas, vol. 5, edited by Ron Tyler, p. 983. The Texas State Historical Association, Austin.

Jenkins, Edloe A.

1996 Goree, Texas. In The New Handbook of Texas, vol. 3, edited by Ron Tyler, p. 252. The Texas State Historical Association, Austin.

Johnson, Elmer H.

1931 The Natural Regions of Texas. The University of Texas Bulletin No. 3113. Bureau of Business Research, Research Monograph No. 8. The University of Texas at Austin.

An under-used, but fundamental, text for historians and cultural geographers that clearly describes climatic, geological, vegetational, and other variables that affect regional economics, human behavior, and history.

Jones, Leon 2002

Interviewed by Martha Doty Freeman, Haskell, Texas, 17 July 2002. 
Source helpful to placing the cotton industry of the 1990s in context; good description of the workings of a cotton gin.

Jones, Morgan

$1898 \mathrm{a}$

$1898 \mathrm{~b}$

1901

$1902 \mathrm{a}$

$1902 b$

[Jones, Morgan]

1907

1915

[1915-1916]

Kean, E. S. 1909

Keeler, D. B. 1907

1908

$1909 \mathrm{a}$

$1909 b$
Letter from Morgan Jones, Fort Worth, Texas, May 28, 1898, to General G. M. Dodge, New York City. Grenville M. Dodge Papers, Volume 15, State Historical Society of Iowa-Des Moines.

Letter from Morgan Jones, Fort Worth, Texas, September 25, 1898, to General G. M. Dodge, New York [City]. Grenville M. Dodge Papers, Volume 15, State Historical Society of IowaDes Moines.

Letter from Morgan Jones, Wichita Falls, Texas, April 29, 1901, to General G. M. Dodge, New York City. Grenville M. Dodge Papers, Volume 16, State Historical Society of Iowa-Des Moines.

Letter from Morgan Jones, Wichita Falls, Texas, April 9, 1902, to General G. M. Dodge, New York. Grenville M. Dodge Papers, Volume 17, State Historical Society of Iowa-Des Moines.

Letter from Morgan Jones, Wichita Falls, Texas, June 20, 1902, to General G. M. Dodge, New York City. Grenville M. Dodge Papers, Volume 17, State Historical Society of Iowa-Des Moines.

Letter from [Morgan Jones], [n.p.], September 24, 1907, to C. V. Dodge, Beaumont, Texas. File 50264, Box 206, Fort Worth \& Denver Railway Collection, Southwest Collection, Texas Tech University, Lubbock.

Letter from [Morgan Jones], [n.p.], April 9, 1915, to T. Bomar, Ft. Worth, Texas. Financial documents, 1902-1944, Microfilm J78C, Reel 1, p. 231. Southwest Collection, Morgan Jones Collection, Texas Tech University, Lubbock.

Documents in this collection pertaining to the Wichita Valley line are helpful in illuminating Jones's investments, not only in railroads, but also in land and a variety of companies that dealt in agriculture and utilities. ${ }^{21}$

Statement of Expendatures [sic] from Fund Arising from Assessment Upon Stock of Haskell Ice Light Co. Financial documents, 1902-1944, Microfilm J78C, Reel 1, n.p., Southwest Collection, Morgan Jones Collection, Texas Tech University, Lubbock.

Letter from E. S. Kean, Abilene, Texas, January 17, 1909, to D. B. Keeler, Fort Worth, Texas. File 50383, Box 208, Fort Worth \& Denver Railway Collection, Southwest Collection, Texas Tech University, Lubbock.

Letter from D. B. Keeler, Fort Worth, Texas, May 31, 1907, to Frank Trumbull, New York City. File 50140, Box 206, Fort Worth \& Denver Railway Collection, Southwest Collection, Texas Tech University, Lubbock.

Letter from D. B. Keeler, Fort Worth, Texas, February 8, 1908, to S. M. Hudson. File 50122, Box 206, Fort Worth \& Denver Railway Collection, Southwest Collection, Texas Tech University, Lubbock.

Letter from D. B. Keeler, [n.p.], March 1, 1909, to G. F. Cotter, Ft. Worth, Texas. File 50044, Box 205, Fort Worth \& Denver Railway Collection, Southwest Collection, Texas Tech University, Lubbock.

Letter from D. B. Keeler, On F. W. \& D. C., June 10, 1909, to G. F. Cotter, Fort Worth, Texas.

${ }^{21}$ This comment generally pertains to entries from the Morgan Jones Collection. 
File 50425, Box 208, Fort Worth \& Denver Railway Collection, Southwest Collection, Texas Tech University, Lubbock.

1910 Letter from D. B. Keeler, at Stamford, Texas, July 1, 1910, to H. A. Gausewitz, Wichita Falls, Texas. File 50085, Box 205, Fort Worth \& Denver Railway Collection, Southwest Collection, Texas Tech University, Lubbock.

1912 Letter from D. B. Keeler, On Line, March 8, 1912, to A. D. Parker, Denver [Colorado]. File 50808, Box 211, Fort Worth \& Denver Railway Collection, Southwest Collection, Texas Tech University, Lubbock.

1913 Letter from D. B. Keeler, [n.p.], August 22, 1913, to A. D. Parker, Denver [Colorado]. File 50869, Box 211, Fort Worth \& Denver Railway Collection, Southwest Collection, Texas Tech University, Lubbock.

1914 Letter from D. B. Keeler, [n.p.], August 10, 1914, to F. S. Hastings, Stamford, Texas. File 50232, Box 206, Fort Worth \& Denver Railway Collection, Southwest Collection, Texas Tech University, Lubbock.

Kelly, Louise (compiler)

$1982 \quad$ Wichita County Beginnings. Eakin Press, Burnet, Texas.

Summary history of Wichita County, focusing on historical Indian occupation, early European and Euro-American exploration, settlement beginning in 1855, establishment of ranches, creation of the county, importance of farming, construction of railroads and branch lines, and development of the oil industries. Includes biographies and community histories.

Knox County History Committee

1966 Knox County History. The Haskell Free Press, Haskell, Texas.

Broad overview of Knox County with helpful information about the development of the cotton, grain, cattle, and oil and gas industries; includes community histories that provide data about agricultural-related businesses.

Laxson, Homer C.

1958 Economic Survey of Wichita County, Texas. Bureau of Business and Economic Research at Midwestern University, Wichita Falls.

Good treatment of county history and analysis of population changes; excellent analysis of events that have impacted the county's population statistics.

Leffler, John $1996 a$

$1996 \mathrm{~b}$

Lewis, Monte 1996

Loftin, Jack 1979
Haskell County. In The New Handbook of Texas, vol. 3, edited by Ron Tyler, pp. 501-502. The Texas State Historical Association, Austin.

Taylor County. In The New Handbook of Texas, vol. 6, edited by Ron Tyler, pp. 223-225. The Texas State Historical Association, Austin.

Archer County. In The New Handbook of Texas, vol. 1, edited by Ron Tyler, pp. 224-225. The Texas State Historical Association, Austin.

Trails Through Archer. Eakin Publications, Burnet, Texas.

General Archer County history beginning with prehistoric Indian occupation and extending through Spanish, French, and Anglo exploration and occupation; and development of military and trade trails, the livestock and oil industries.

McConnell, H. G.

1907 Letter from H. G. McConnell, Haskell, Texas, October 12, 1907, to D. B. Keeler, Fort Worth, Texas. File 50231, Box 206, Fort Worth \& Denver Railway Collection, Southwest Collection, Texas Tech University, Lubbock. 
McDaniel, Mary Kerr

1977 Reflections of Ninety Years. G. McDaniel, Beverly Hills, California.

Highly personal memoir of life in and around Seymour, Baylor County.

Munday Historical Society (compiler)

1981

"My Home Town": A History of Munday, Texas. McCrain Publishing Co., Archer City.

General information about the establishment and growth of Munday, agriculture in the area, and the impact of the railroad; histories of churches, public schools, banks, the newspaper, and clubs; descriptions of local life and customs; biographies of residents.

Newberry, Mary Y., and Kirby Clayton

1963 Your County Program: Jones County. N.p., n.p.

Statistical analysis of labor, agriculture, industry, organizations, health and public welfare, human resources, and other topics.

Odintz, Mark

1996

Jones County. In The New Handbook of Texas, vol. 3, edited by Ron Tyler, pp. 994-995. The Texas State Historical Association, Austin.

O'Keefe, Ruth Jones 1969

Archer County Pioneers. Pioneer Book Publishers, Inc., Hereford, Texas.

Overview history of Archer County that reprints pertinent articles from newspapers and by a variety of authors; description of early ranches and oil development; biographies of pioneer families.

Overton, Richard C.

1953 Gulf to Rockies: The Heritage of the Fort Worth and Denver-Colorado and Southern Railways, 1861-1898. University of Texas Press, Austin.

Excellent study of the creation, construction, and expansion of the Fort Worth and Denver-Colorado and Southern Railways and their feeder lines through the project area. Includes helpful reference materials, particularly to the Grenville M. Dodge Collection at the State Historical Society of Iowa-Des Moines.

Parfet, Ion 1956

The Trail of the Diamond Duster. N.p., [Wichita Falls,].

An imaginative treatment of the history of Wichita County, focusing on Wichita Falls and seen through the eyes of a fictitious character strongly reminiscent of Joseph A. Kemp.

Pool, William C. 1975

A Historical Atlas of Texas. Encino Press, Austin.

Like The New Handbook of Texas, not always a reliable source of information, but good for general data, particularly regarding droughts and railroad construction.

Poole, J. E. $1911 \mathrm{a}$

Letter from J. E. Poole, Haskell, Texas, September 30, 1911, to W. B. Shepperd, Wichita Falls, Texas. File 50627, Box 209, Fort Worth \& Denver Railway Collection, Southwest Collection, Texas Tech University, Lubbock.

1911b Letter from J. E. Poole, Haskell, Texas, October 6, 1911, to J. B. Keeler, Fort Worth, Texas. File 50627, Box 209, Fort Worth \& Denver City Railway Collection, Southwest Collection, Texas Tech University, Lubbock.

Proctor \& Gamble

Proctor \& Gamble Cotton Crop Report. In The Cotton Oil Press II (September):24.

Snapshot of the effects of the 1917-1918 drought on Texas cotton crops.

Proctor \& Gamble Co.

Special Report on the Cotton Crop. In The Cotton Oil Press II (September):38-39.

Snapshot of the effects of the 1917-1918 drought on Texas cotton crops. 
Ray, Earl Vernon

1989 The Sailor's Destiny. E. V. Ray, Cisco, Texas.

History of the development of the Samuel Butman Ranch in Jones County.

Ricci, Connie

1996

Anson, Texas. In The New Handbook of Texas, vol. 1, edited by Ron Tyler, p. 193. The Texas

State Historical Association, Austin.

Sanborn Map Company

$1892 \quad$ Seymour, Baylor County, Texas.

1908a Anson, Jones County, Texas.

1908b Haskell, Haskell County, Texas.

1908c Seymour, Baylor County, Texas.

1908d Stamford, Jones County, Texas.

1913a Haskell, Haskell County, Texas.

1913b Stamford, Jones County, Texas.

1914 Anson, Jones County, Texas.

1916 Seymour, Baylor County, Texas.

1921 Haskell, Haskell County, Texas.

1922 Anson, Jones County, Texas.

1925a Munday, Knox County, Texas.

1925b Seymour, Baylor County, Texas.

1930 Seymour, Baylor County, Texas.

1931 Haskell, Haskell County, Texas.

1940 Seymour, Baylor County, Texas.

1941 Haskell, Haskell County, Texas.

1942 Munday, Knox County, Texas.

1949 Haskell, Haskell County, Texas.

Essential records of the development of towns and of their constituent businesses. However, mistakes do occur, and information on the maps should be used in conjunction with county records.

Sanders, R. S., and Betty Sanders

1986 Just Passing Through Weinert: A History of Northeastern Haskell County, Texas. Quality Printing Company, Inc., Abilene, Texas.

General historical treatment of exploration and settlement of northeast Haskell County and Weinert; identification and history of business firms, the railroad, communication, education, and rural community growth and decline; and family histories.

Shelton, Hooper, and Homer Hutto

1978 First 100 Years of Jones County, Texas. Shelton Press, Stamford, Texas. 
General history of the county, with information about development of towns and early settlers and their descendants.

Sherrill, R. E. 1965

Haskell County History. The Haskell Free Press, Haskell, Texas.

Sherrill occasionally misses dates by a year or two, but his is the single most important source of information about the project area in general and Haskell and Haskell County in particular. A businessman who kept detailed crop and weather records, Sherrill deftly made the connections among weather events, population movements, crop failures and successes, business development, and railroad construction.

Sledge, Robert Watson

1986 God's Field, God's Building:The Lytle Gap-Potosi Methodist Church, 1879-1982. Potosi United

Methodist Church, Abilene, Texas.

Church-based community history of the eastern Taylor and western Callahan Counties area.

Spence, Vernon Gladden

1971 Colonel Morgan Jones, Grand Old Man of Texas Railroading. University of Oklahoma Press, Norman.

Useful biographical treatment of Morgan Jones, who spearheaded construction of the Wichita Valley Railway and Railroad and of the Abilene and Northern Railroad through the project area.

Stamford Commercial Club, The

[1908?] Stamford, the Hub of the Land of Opportunities, Central West Texas. The Fastest Growing Town in Texas. The Place Where the Cotton Grows. Stamford News Print, Stamford, Texas. Promotional brochure for Stamford, "where the cotton grows," with brief descriptions of local industries and lists of opportunities for investment.

Sterley, W. F.

1911

Letter from W. F. Sterley, Fort Worth, Texas, November 9, 1911, to D. B. Keeler, [Fort Worth, Texas]. File 50780, Box 210, Fort Worth \& Denver Railway Collection, Southwest Collection, Lubbock.

Texas. Comptroller of Public Accounts

1921-1959 Haskell County, Texas, ad valorem tax records.

See comments for Haskell County legal records.

Texas. Secretary of State

1906a Charter No. 15136: Brazos Oil \& Light Company.

1906b Charter No. 15510: Haskell Lumber Company.

1910 Charter No. 21854: Haskell Creamery.

1911 Charter No. 23574: Knox City Cotton Oil Company.

1915a Charter No. 28230: Haskell Ice \& Light Company.

1915b Charter No. 29178: Haskell Bonded Warehouse Company.

1917 Charter No. 31817: West Texas Utilities Company.

1918 Charter No. 32736: Western Cotton Oil Company.

1922 Charter No. 38339: Duncan Gin Company.

1923 Charter No. 39354: Haskell Laundry Company. 
1924 Charter No. 41975: Haskell County Fair Association.

1925 Charter No. 44366: Haskell Hotel Company.

1928 Charter No. 50959: Texas Farm Bureau Gin Company.

1929a Charter No. 55146: Haskell Amusement Company.

1929b Charter No. 55227: Farmers Co-Operative Society No. 2 of Haskell, Texas.

1932 Charter No. 61891: Haskell Electric Gin, Inc.

1935 Charter No. 67472: Haskell Cooperative Gin Company.

1936 Charter No. 72147: Haskell County Farmer's Co-operative Gin Company, of Haskell, Haskell County, Texas.

1959 Charter No. 155925: Haskell County Warehouse and Compress Company, Inc.

1984 Charter No. 693644: Texas Compress \& Warehouse Corporation. An important primary source of information about company formation and the individuals involved.

Texas. Thirty-Third Legislature

[1914] General Laws of the State of Texas Passed at the Second Called Session of the Thirty-Third Legislature Convened August 24, 1914, and Adjourned September 22, 1914. N.p., [Austin].

Helpful information about state laws that affect agricultural production, investment, and company formation. ${ }^{22}$

Texas. Thirty-Ninth Legislature

$1926 \quad$ Revised Civil Statutes of the State of Texas Adopted at the Regular Session of the ThirtyNinth Legislature 1925 Including Constitution of the United States and Constitution of the State of Texas. Vol. I. A. C. Baldwin \& Sons, Austin.

Texas. Forty-Third Legislature

[1934] General and Special Laws of the State of Texas Passed by the Forty-Third Legislature at the Second Called Session Convened at the City of Austin, January 29, 1934, and Adjourned February 27, 1934. N.p., [Austin].

Thomas, O. P. 1907 a

Letter from O. P. Thomas, Abilene, Texas, November 25, 1907, to D. B. Keeler, Fort Worth, Texas. File 50022, Box 205, Fort Worth \& Denver Railway Collection, Southwest Collection, Lubbock.

1907b Letter from O. P. Thomas, Abilene, Texas, December 6, 1907, to D. B. Keeler, Ft. Worth, Texas File 50022, Box 205, Fort Worth \& Denver Railway Collection, Southwest Collection, Lubbock.

Trumbull, Frank

1907 Letter from Frank Trumbull, New York, May 31, 1907, to D. B. Keeler, Fort Worth, Texas. File 50120, Box 206, Fort Worth \& Denver Railway Collection, Southwest Collection, Texas Tech University, Lubbock.

Tyler, Ron (editor in chief)

1996a Agricultural Adjustment Administration. In The New Handbook of Texas, vol. 1, edited by

${ }^{22}$ This comment generally pertains to entries that refer to laws passed by the Texas legislature. 
Ron Tyler, pp. 56-57. The Texas State Historical Association, Austin.

1996b Haskell, Texas. In The New Handbook of Texas, vol. 3, edited by Ron Tyler, pp. 500-501. The Texas State Historical Association, Austin.

University of Texas. Bureau of Business Research

1948 An Economic Survey of Jones County Prepared for The Texas and Pacific Railway Company. University of Texas. Bureau of Business Research, Austin.

Economic survey of part of the area served by the Texas and Pacific Railway Company. Includes statistical analyses of numerous aspects of natural, human, and capital resources; population, agricultural, mercantile, and oil and gas data. Briefly reviews early economic development and factors influencing growth of the county.

1949 An Economic Survey of Taylor County Prepared for The Texas and Pacific Railway Company. University of Texas. Bureau of Business Research, Austin.

See comments for University of Texas. Bureau of Business Research 1948.

Voellinger, Melissa W., and Eugene R. Foster

1991 An Inventory and Assessment of Historic Architectural Resources With the Vera Project Area, Knox and Baylor Counties, Texas. Espey, Huston \& Associates, Inc., Austin.

General overview of county histories (Baylor and Knox), identification of historic properties, and association of architectural styles with historical overview.

Wade, H. D. 1909

Letter from H. D. Wade, Stamford, Texas, November 9, 1909, to D. Miller, Chicago. File 50381, Box 208, Fort Worth \& Denver Railway Collection, Southwest Collection, Texas Tech University, Lubbock.

[Wade, Homer D.]

1910 Letter from [Homer D. Wade], [Stamford, Texas], September 6, 1910, to [R. H.] Baker, [n.p.]. File 50734, Box 210, Fort Worth \& Denver Railway Collection, Southwest Collection, Texas Tech University, Lubbock.

1912 Letter from [Homer D. Wade], [Stamford, Texas], September 10, 1912, to S. M. Swenson \& Sons, New York City. File 50232, Box 206, Fort Worth \& Denver Railway Collection, Southwest Collection, Texas Tech University, Lubbock.

1915 Letter from [Homer D. Wade], [Stamford, Texas], September 23, 1915, to S. M. Swenson and Sons, New York City. File 50232, Box 206, Fort Worth \& Denver Railway Collection, Southwest Collection, Texas Tech University, Lubbock.

Wade, Homer D. 1913

Letter from Homer D. Wade, [n.p.], September 1, 1913, to S. M. Swenson \& Sons, New York City. File 50232, Box 206, Fort Worth \& Denver Railway Collection, Southwest Collection, Texas Tech University, Lubbock.

1914

Letter from Homer D. Wade, [n.p.], January 8, 1914, to S. M. Swenson \& Sons, New York City. File 50232, Box 206, Fort Worth \& Denver Railway Collection, Southwest Collection, Texas Tech University, Lubbock.

Webb, Walter Prescott

$1931 \quad$ The Great Plains. Ginn and Company, Boston.

General study that sometimes over-generalizes but is helpful in delineating areas marginally suitable for agriculture.

Werner, George C.

1996a Burlington System. In The New Handbook of Texas, vol. 1, edited by Ron Tyler, pp. 846-847. The Texas State Historical Association, Austin. 
1996b Colorado and Southern Railway. In The New Handbook of Texas, vol. 2, edited by Ron Tyler, p. 230. The Texas State Historical Association, Austin.

1996c Wichita Valley Railroad. In The New Handbook of Texas, vol. 6, edited by Ron Tyler, p. 960. The Texas State Historical Association, Austin.

Western Land Company

[1880] A Descriptive Pamphlet of Northwest Texas, Issued Monthly by the Western Land Company, Seymour, Baylor County, Texas. Miller \& Ross, Weatherford, Texas.

A promotional piece that expresses the "hype" associated with development of this part of Texas and reveals plans for its agricultural and urban development.

West Texas Utilities Company

1927 Out of the Dreams of Yesterday: West Texas Utilities Company. West Texas Utilities Company, [Abilene].

Superb overview of the activities of the West Texas Utilities Company during the 1920s, with excellent photographs and descriptions of the associated facilities. Largely through inference, the company describes the connections among its affiliated companies and the interdependence of electrical generation plants, dams, ice plants, gins, mills and elevators, oil and gas facilities, and municipal infrastructure.

White, Raymond Elliott

1957 The History of the Texas Cotton Ginning Industry, 1822-1957. Master's thesis, The University of Texas at Austin.

A broad overview of the ginning industry from the plantation period to the twentieth century. Includes helpful information about cooperative ginning and a bibliography that references more in-depth studies, such as those published by the Texas Agricultural Experiment Station in its bulletins.

Wichita County Program Building Committee

$1963 \quad$ Long Range Program for Wichita County, 1963. Wichita County Program Building Committee, [Wichita Falls, Texas].

See comments for University of Texas. Bureau of Business Research 1948. A planning document designed to meet the county residents' needs. Good overview of Wichita County at mid century.

Wichita Falls Chamber of Commerce

[1908?] The Land of Opportunity in the Wichita Falls County of Texas. Marlow \& Huey, Wichita Falls.

Good description of Wichita Falls early the last century, with descriptions of cotton and grain production and specific agricultural-related companies.

Wichita Falls Country Emigration Association

[ca. 1889] The Famous Wichita and Red River Valley Country. Worley, printer, Dallas.

Good promotional brochure with map labeling the area from Wichita County to Haskell as "Wichita Falls County." Crops are emphasized, primarily wheat. The role of the Fort Worth and Denver City Railway is spelled out.

Wichita Falls, Texas. Bureau of Business \& Economic Research. Midwestern University Red River Valley Business Report.

Economic analyses of business enterprises in Wichita County; issues focus on the postWorld War II era.

Williams, Diane E.

$2001 \quad$ Historical Overview, Property Types, and National Register Eligibility Assessments; Environmental Investigations; Highway 277 Right-of-Way Construction, Portions of Archer, Baylor, Knox and Wichita Counties, Texas (Goree to Holliday). Diane E. Williams, Austin.

Broad overview of the northern part of the project area. The historical synthesis is organized on a county-by-county and community-by-community basis, rather than a regional basis. 
Zachry, Juanita Daniel

1980 The Settling of a Frontier: A History of Rural Taylor County. Nortex Press, Burnet, Texas. Provides county-wide information about ranching, crop raising, introduction of cotton, impacts of weather and 1930s government programs; includes histories of communities in Taylor County and associated families.

1999 A Living History: Taylor County and the Big County. Quality Press, Abilene, Texas. A series of short articles describing different landmarks, events, and Taylor County topics, including flight, the Paramount Theater, Wooten Hotel, oil, important residents, the West Texas Fair, etc. 
APPENDIX: Population, Crop, and Livestock Data from Agricultural and Population Censuses for Wichita, Archer, Baylor, Knox, Haskell, Jones, and Taylor Counties 



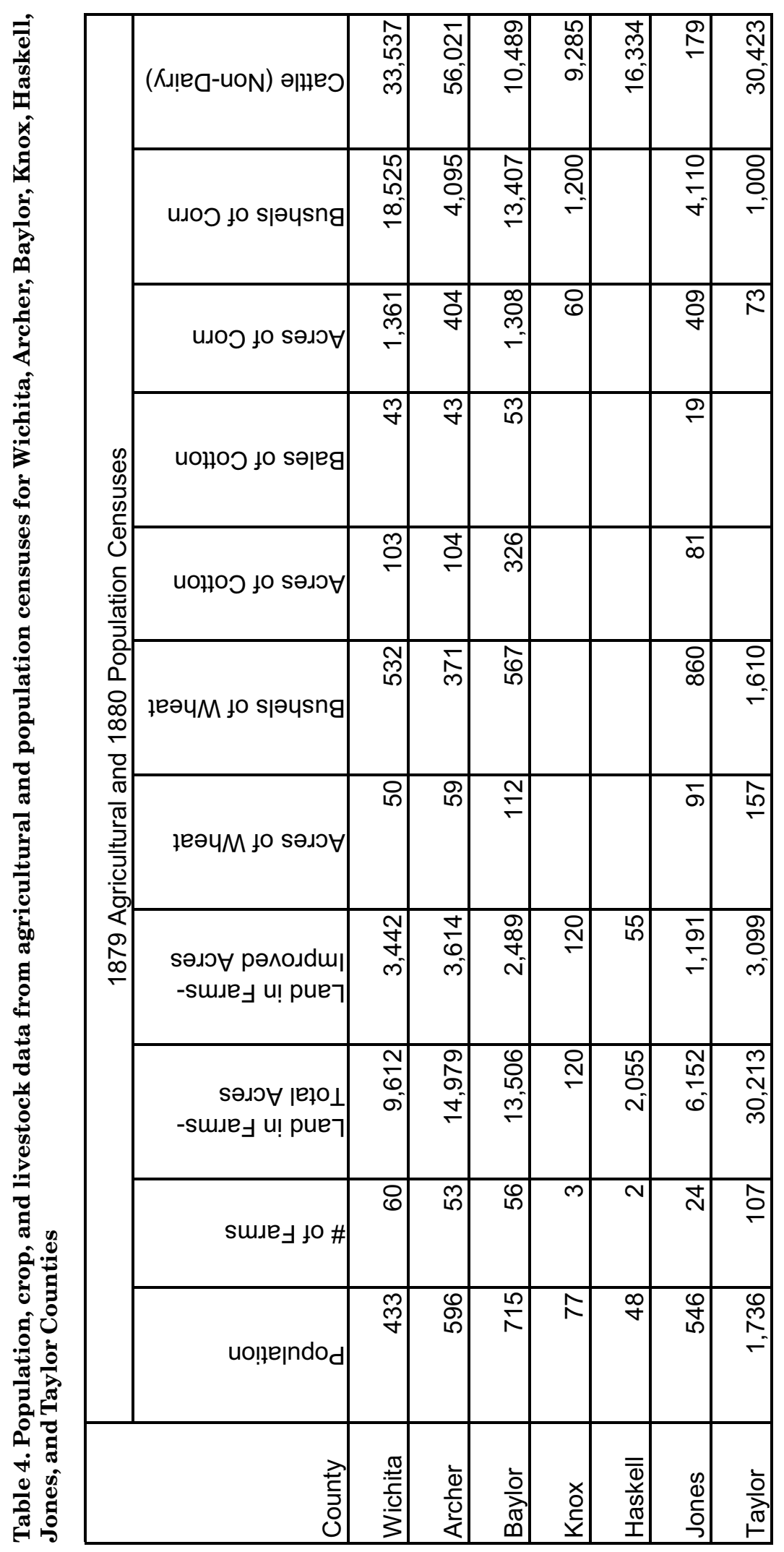




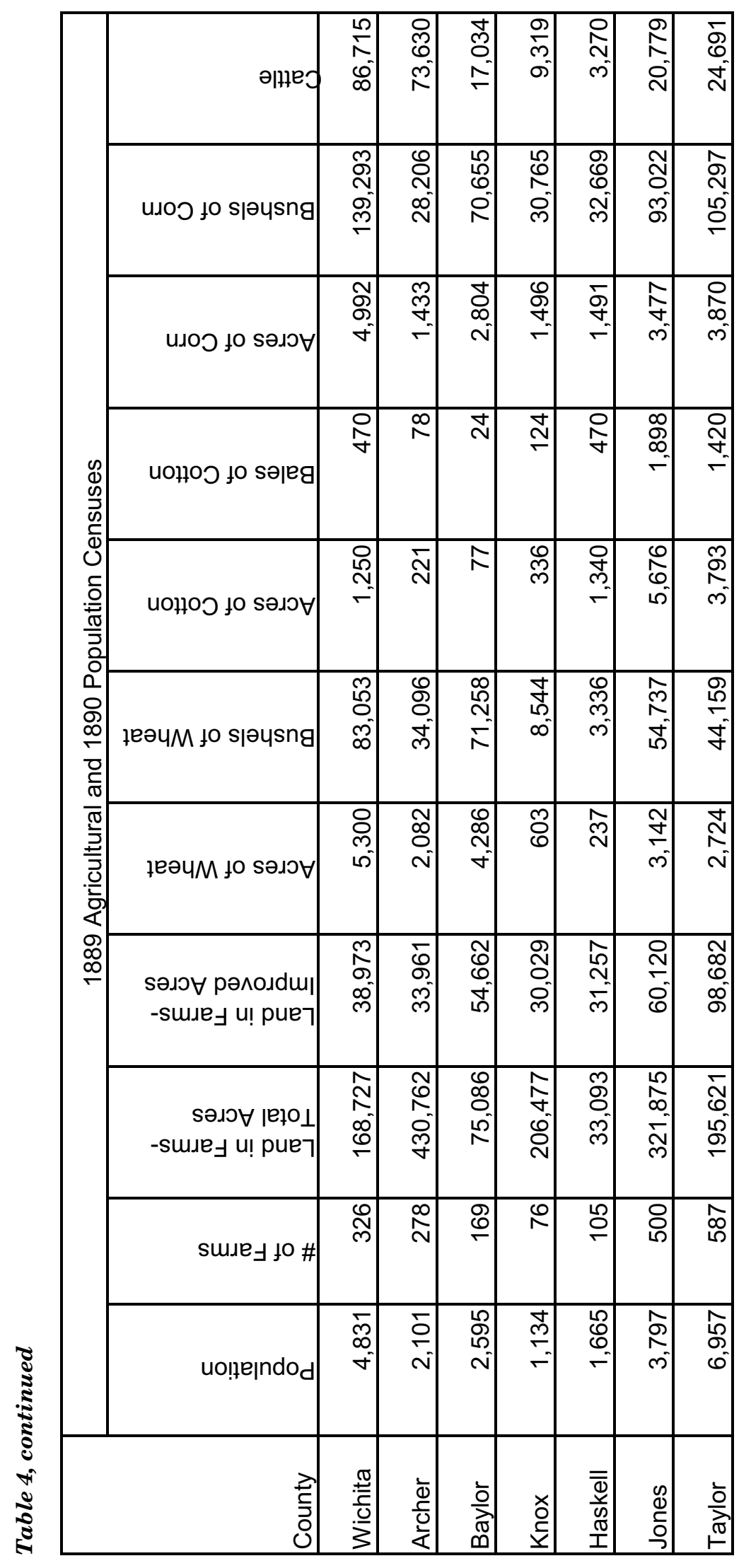




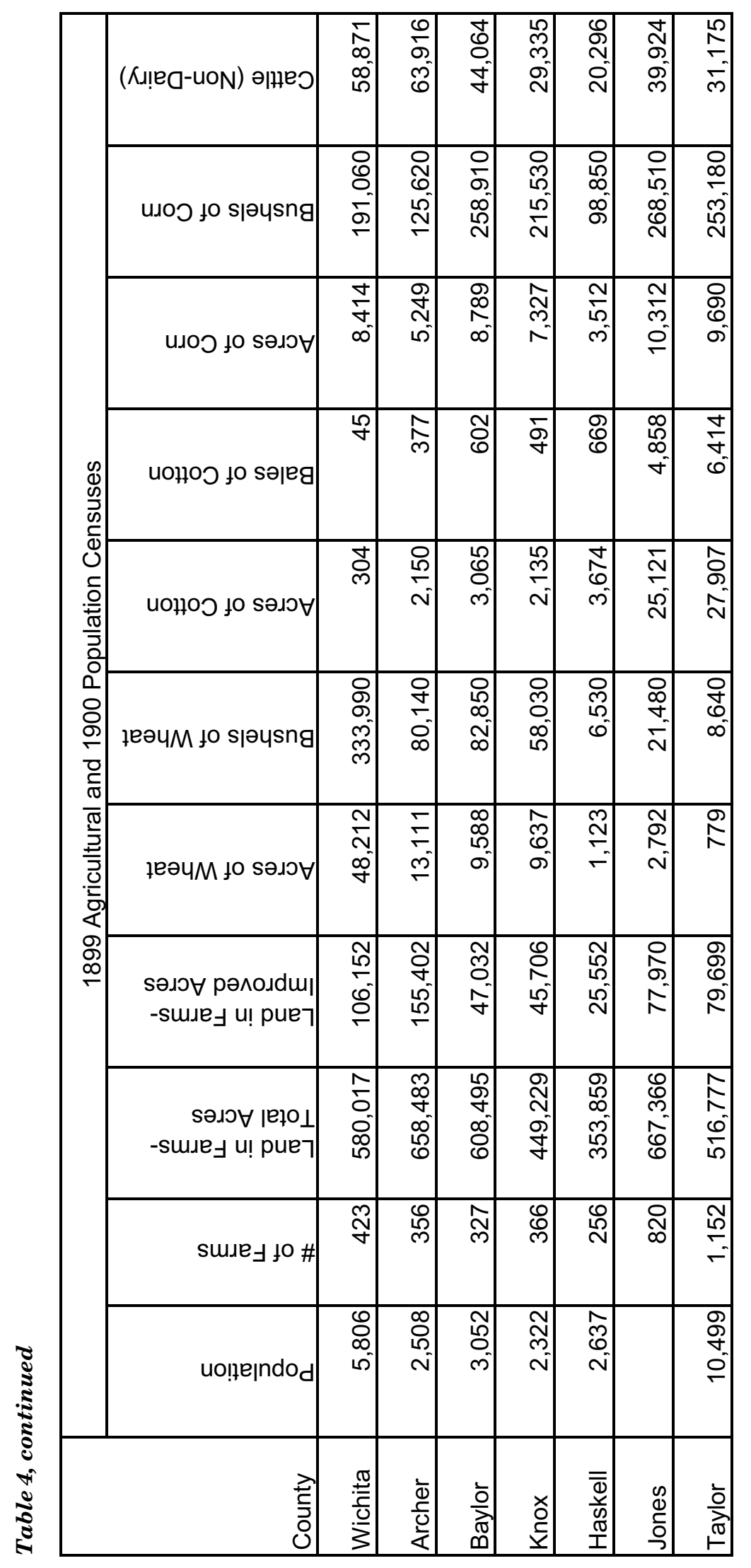




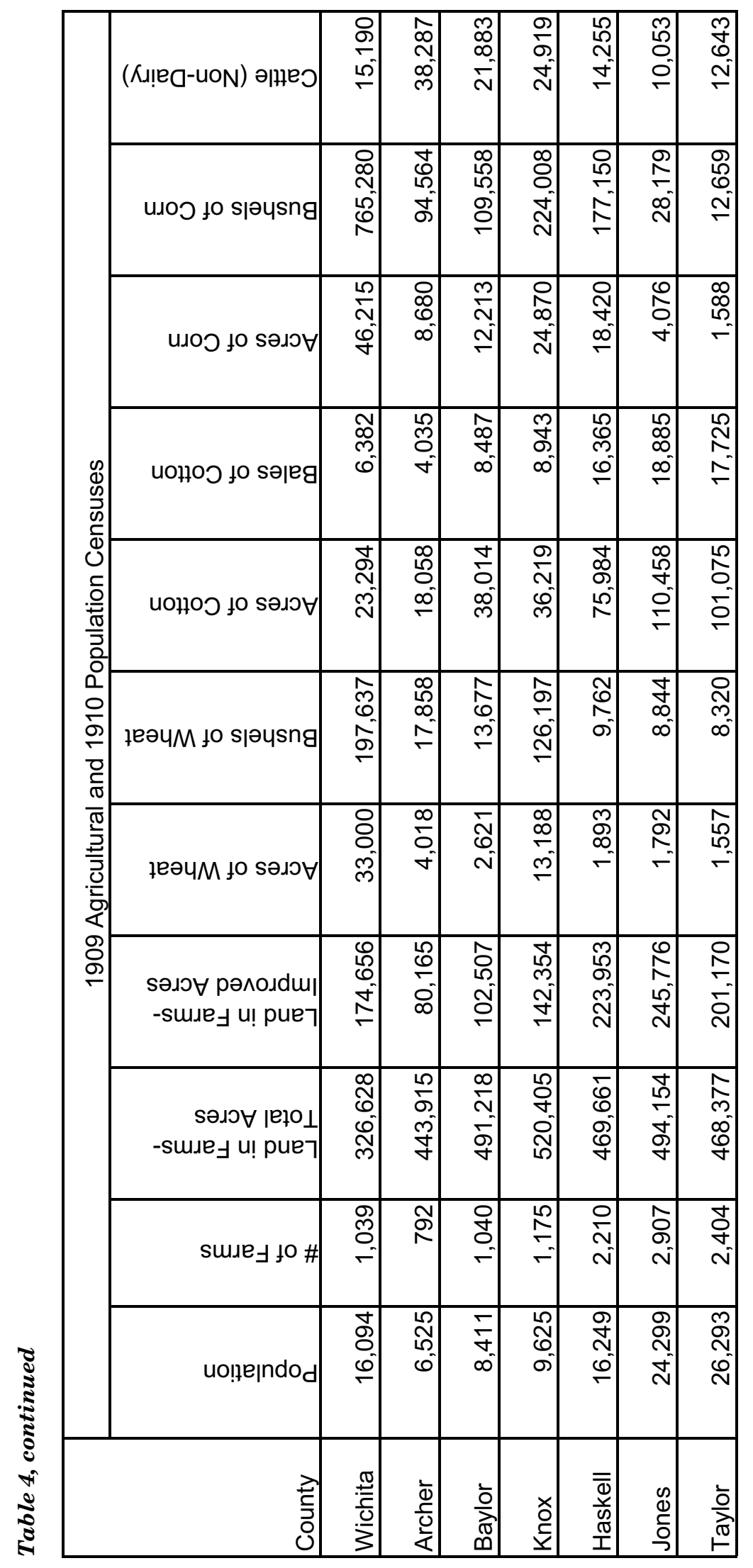




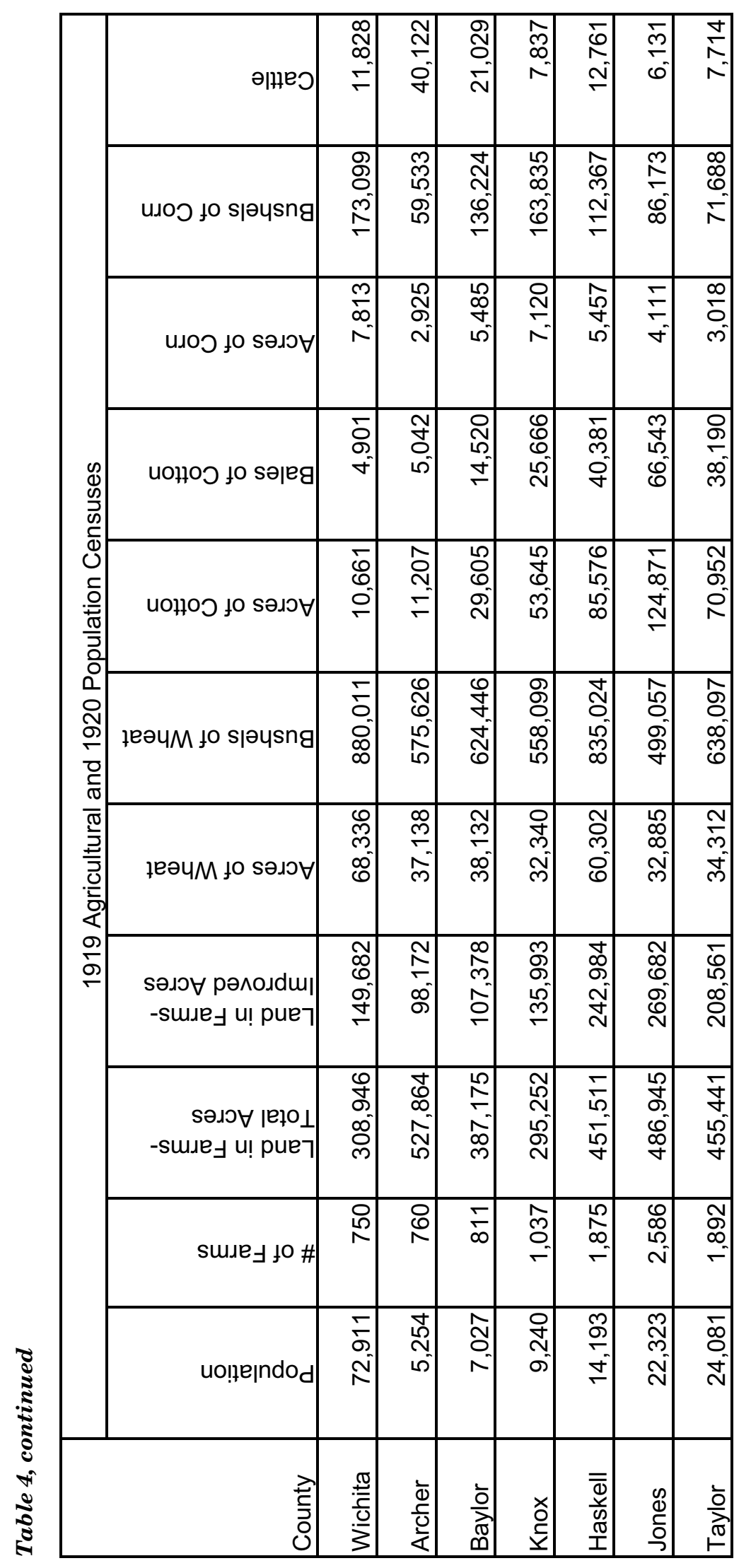




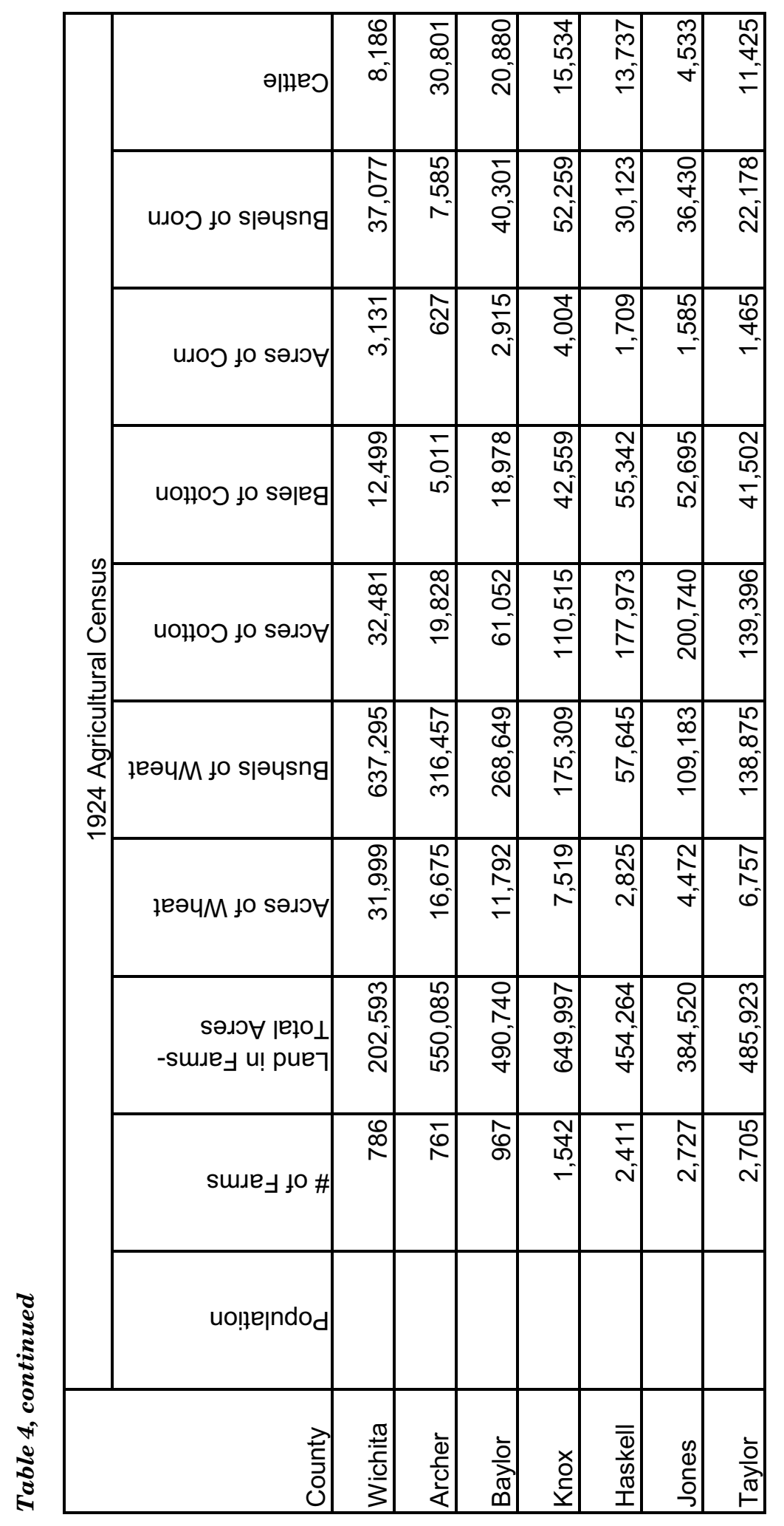




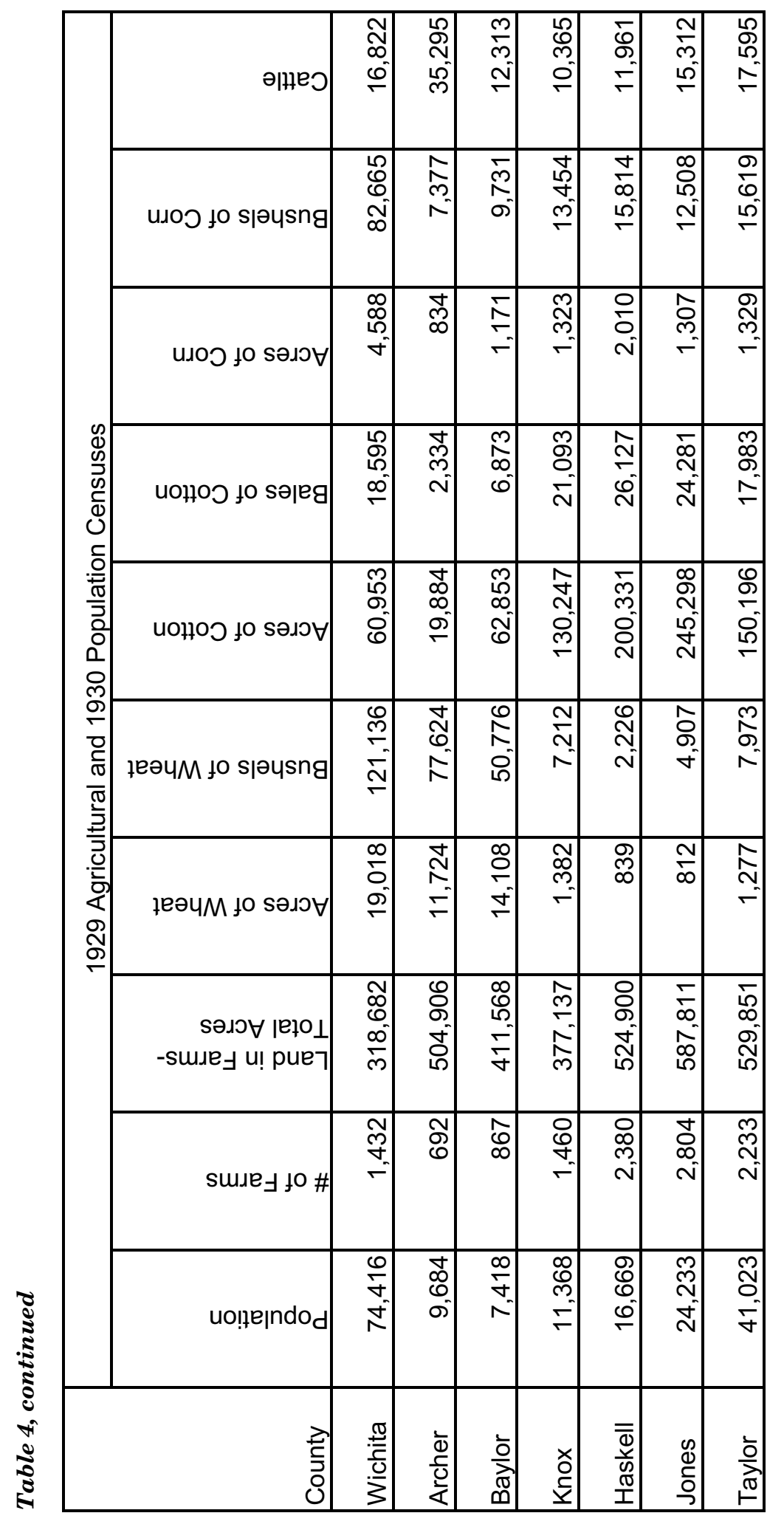




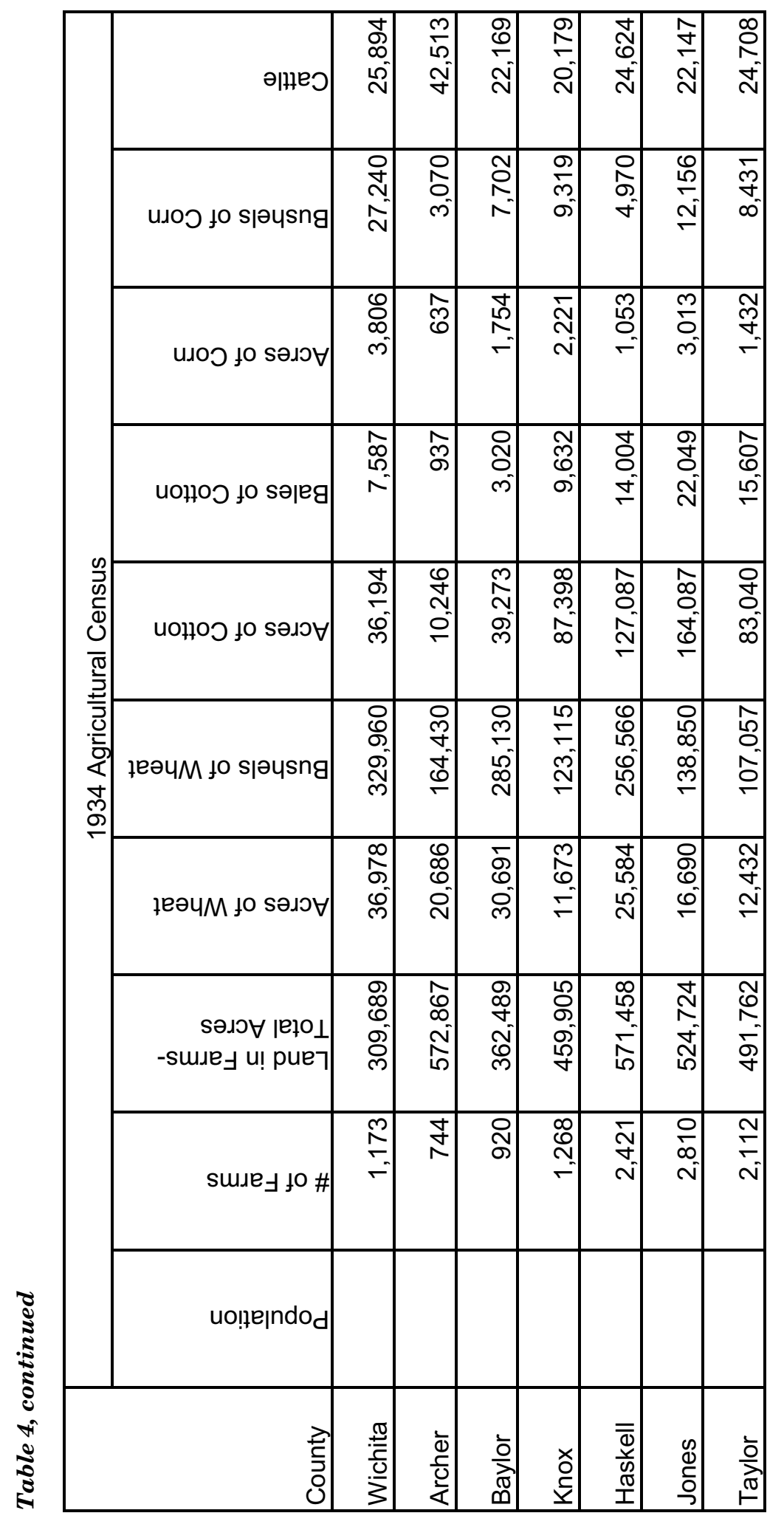




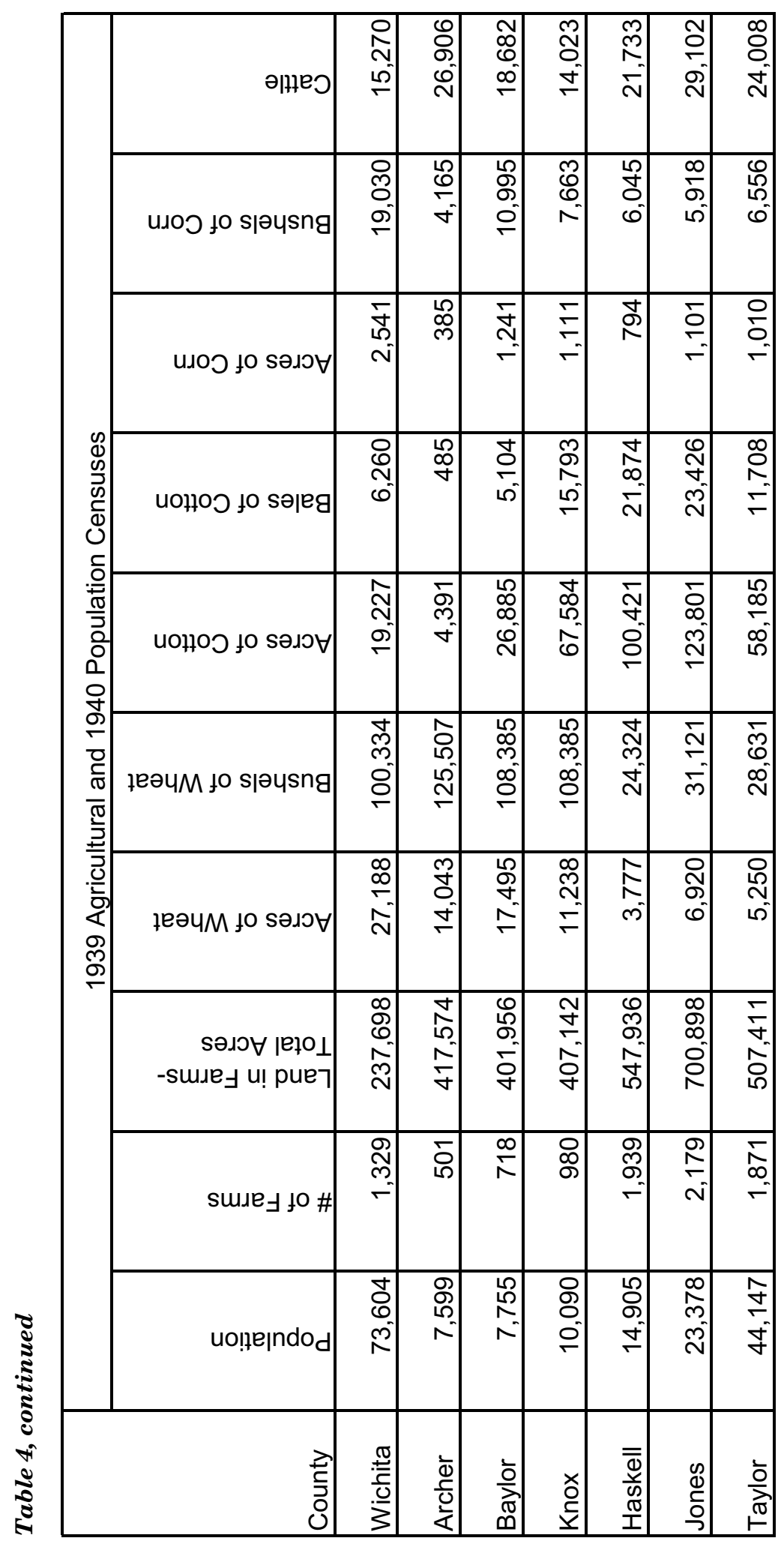




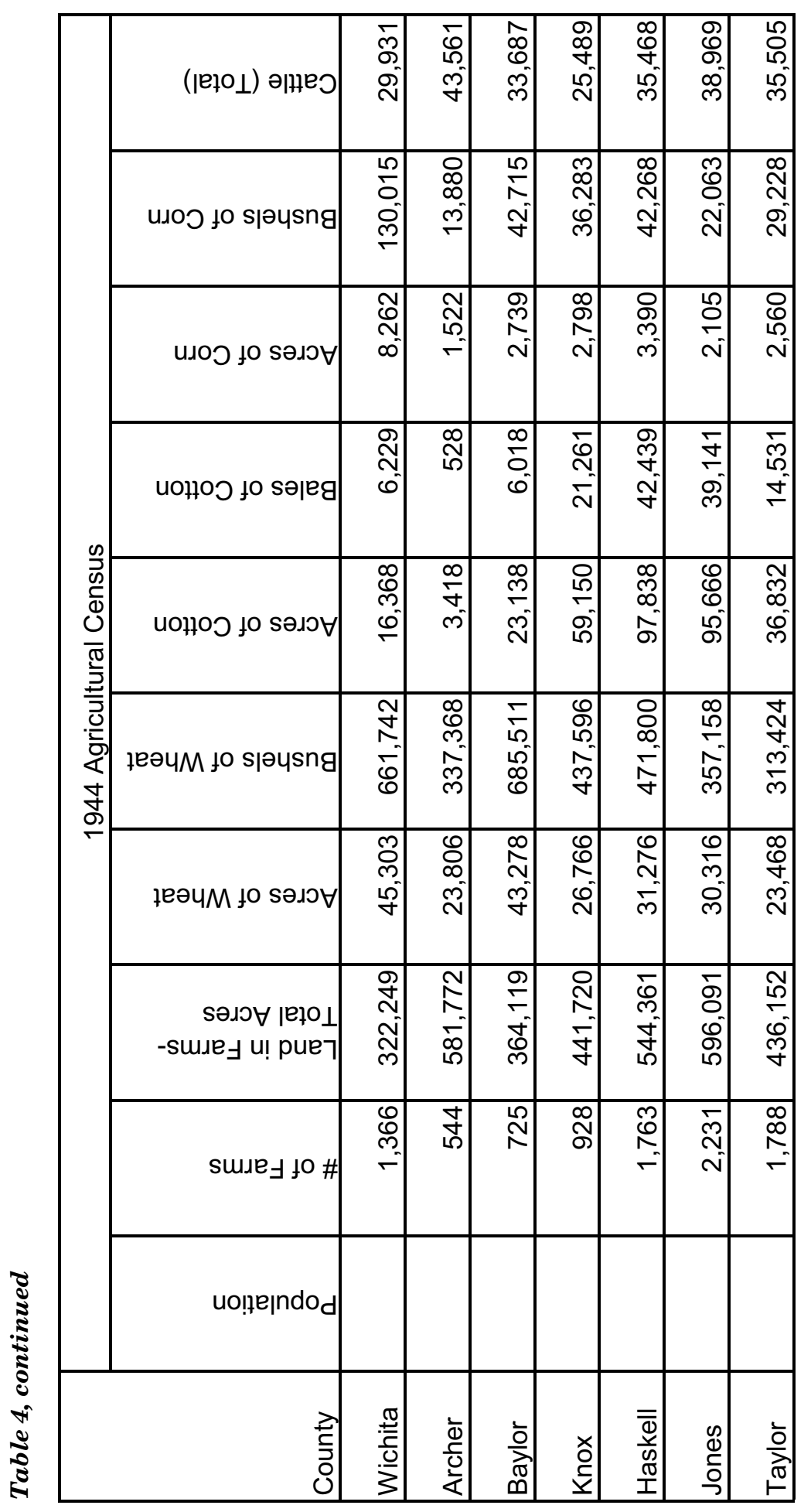




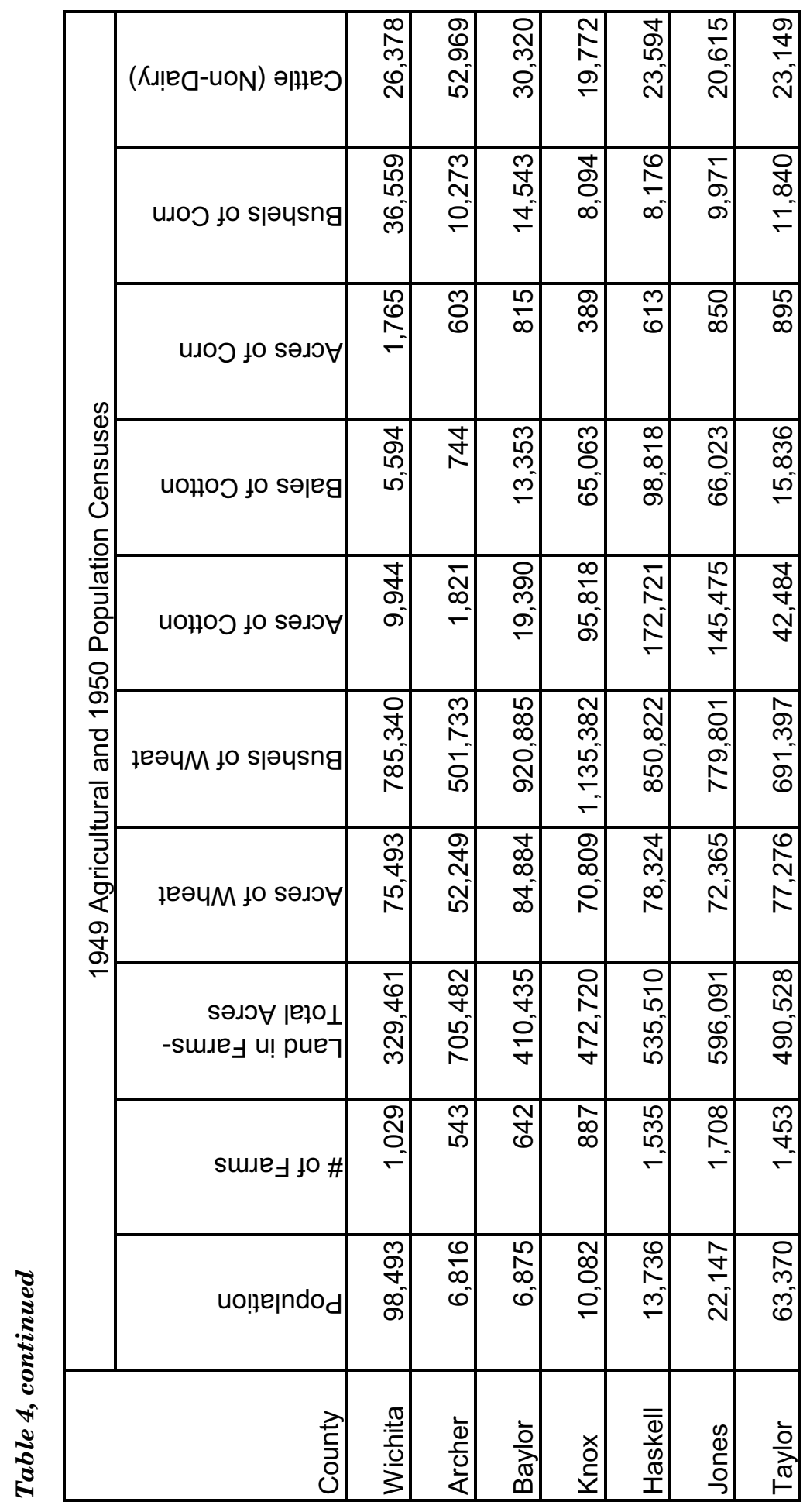




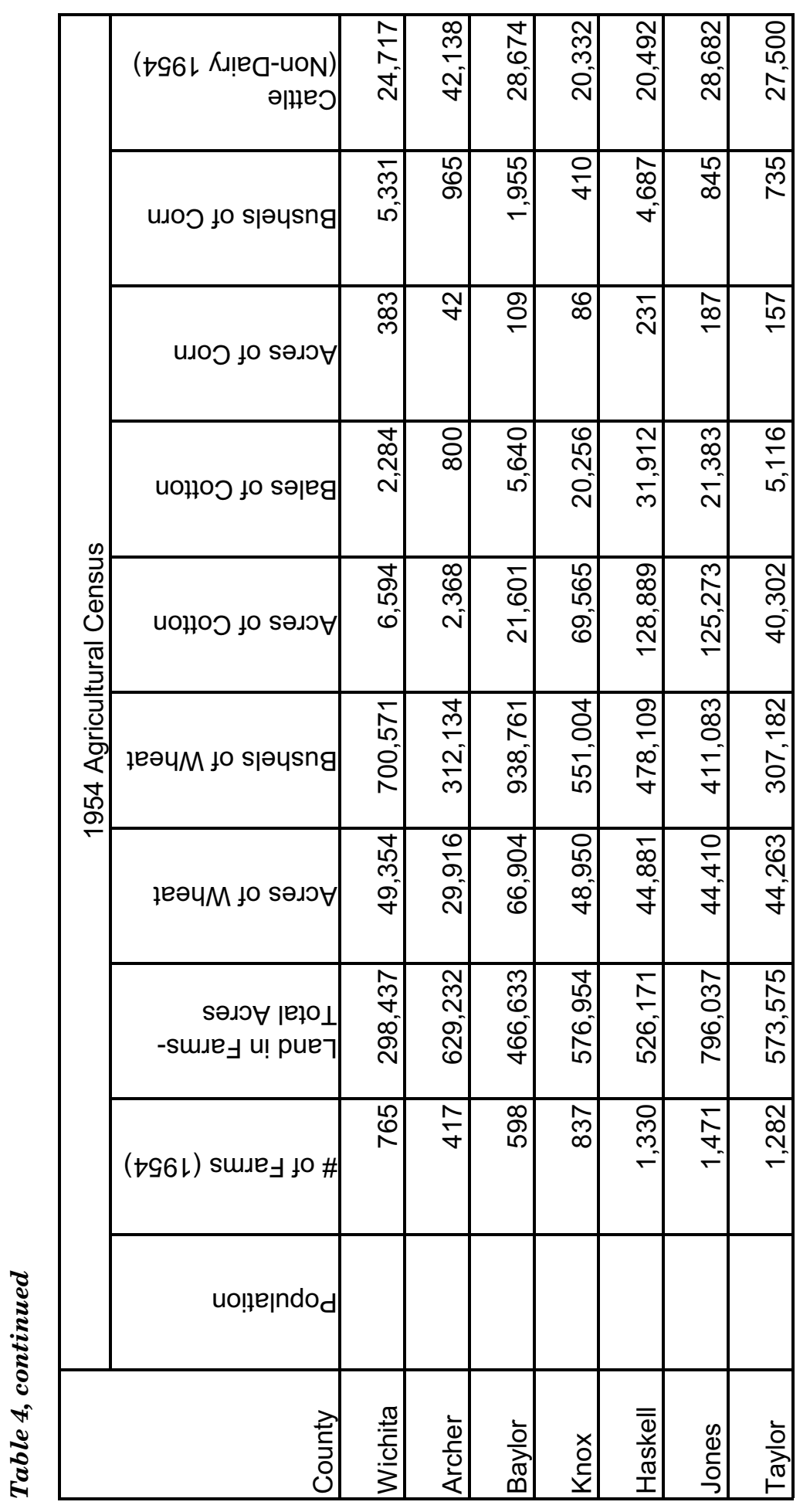




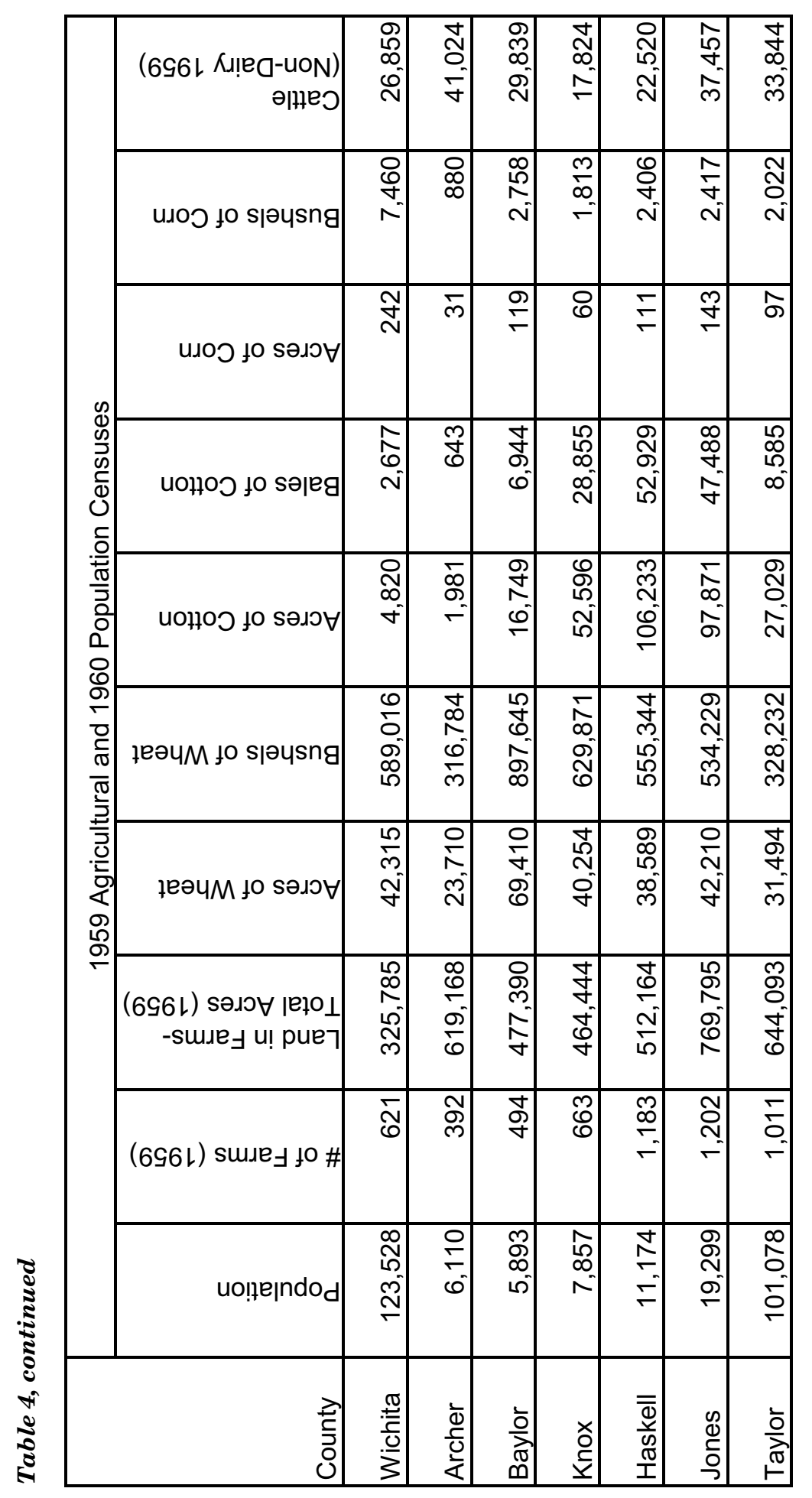





\section{INDEX}

This index exclusively references surnames and place names. The names of cities, towns, communities, and waterways all refer to Texas locations unless indicated otherwise with the state listed parenthetically.

\section{A}

Abbott, J. M. 19

Abilene $2,4,6,7,10,11,18,19,20$, $22,24,25,26,28,29,31,37,45$, 47,48

Adams, A. L. 69

Albany 11

Amarillo 24, 61

Anson 2, 4, 18, 19, 20, 22, 24, 28, $29,31,37,45$

Arapahoe County (Colorado) 48

Archer County 1, 2, 4, 6, 7, 8, 9, 10, $11,12,17,18,19,20,24,25,26$, $28,29,29 \mathrm{n}, 30 \mathrm{n}, 31,37,45$

Armstrong, William 46

Arnolds, M. L. 11

Avis, J. D. 26

\section{B}

Baggett, George 47, 67

Baggett, Silas 7

Baker, W. A. 25

Baldwin, E. M. 52, 67

Baldwin, J. L. 47

Ballinger 52, 67

Barton, Clara 10

Baylor County 1, 2, 4, 6, 7, 8, 9, 11, $12,17,18,19,20,21,24,26,27$, 28, 28n, 29, 30, 31, 31n, 33, 34, $37,38,39,40,45,67$

Beardsley, J. D. 48

Beaumont 24

Bell County 48

Belton 48

Bierce, Mrs. William 51, 61, 69

Bolander, J. F. 11

Bomar, David T. 19 (see also D. T. Bomar)

Bomar, D. T. 49, 57n (see also David T. Bomar)

Bomar, Edmond P. 49, 57n

Bomarton 2, 4, 18, 19, 20, 24, 45

Brazelton, William B. 57

Brazos River 4, 17, 18, 46, 47

Brewington, Charles 57

Brigaman, Terry Joe 69

Brown, Lucy G. 49

Buffalo Gap 8
Buntin, Tom 7

Burns, C. S. 48

Butterworth, William 50, 59

C

California Creek 8, 46

Carlisle, J. C. 48

Carlisle, J. M. 48

Carothers, Alice 49

Carothers, S. E. 49

Chancellor, J. H. 50, 59, 63

Chicago (Illinois) 48

Clack, John B. 7

Clay County 18

Clifton, Catherine E. 68

Clifton, Mart 68

Cogdell, Carl 59

Cogdell, D. C. 50, 59, 63

Cogdell, Earl 50, 59

Colorado 11, 52, 67

Colthrop, Ham 8

Cook, G. W. 47

Coryell County 48

Cottle County 47

Courtney, George 61 (see also George E. Courtney)

Courtney, George E. 50,59 (see also George Courtney)

Courtney, Louthene 60

Cox, Buford 54, 67, 70

Cox, G. 54

Crawford, J. M. 54

Crouch, G. R. 49

Culpepper, A. C. 71

Culpepper, A. W. 71

Culpepper, Annette D. 71

Culpepper, J. R. 71

Culpepper, R. 71

Cureton, William E. 7

Curtis, Mrs. M. A. 54, 67

\section{D}

Dallas 19, 52, 53, 57n, 63, 65, 66, 67

Dallas County 50, 59, 63

Darnell, R. H. 52, 63

Davis, Irene 68

Davis, J. M. 68
Denver (Colorado) 8, 19

Dickens County 47

Dodge, Grenville M. 1, 10, 11, 17, 18, 19

Donnigan, Bill 31

Double Mountain Fork 46, 47

Draper, W. F. 47

Drew, A. D. 54

Duke, J. C. 50, 59, 63

Dulaney, C. A. 51

Duncan, W. A. 52, 63, 70

Dundee 4, 18, 24, 30

Dunagin, J. M. 61

Durrett, Ryus 46

Dwyer, Will 48

\section{$\mathbf{E}$}

Earnest, W. A. 63 (see also William A. Earnest)

Earnest, William A. 48, 49, 57n, 59

Elkins, Clyde F. 65

Elkins, Eula H. 65

Estes, John 10

Eussaga 18

\section{$\mathbf{F}$}

Falls County 48

Fields, J. U. 51

Flowers, W. A. 48

Fort Phantom Hill 7

Fort Worth 7, 8, 10, 19, 22, 24, 49, $57 \mathrm{n}, 61$

Fouts, Ed. F. 54, 65, 66, 67

Francis, C. M. 52, 63, 70

\section{G}

Gainesville 49, 57n

Gatesville 48

Gilbert, Mabel 7

Gholson, John B. 7

Gilliam, C. C. 70

Gilliam, M. H. 70

Gilstrap, J. A. 52, 63

Glisson, A. A. 25

Goff, John 46

Goodwin, W. W. 53 
Goree, R. D. 17 (see also Robert D. Goree)

Goree, Robert D. 10 (see also R. D. Goree)

Goree 2, 4, 11, 18, 19, 20, 24, 26, $29,31,45$

Gould, Jay 10

Grayson County 48

Gregory, B. M. 53

Griffith, Ernest 31, 54, 67

Grindstaff, I. H. 51

Grissom, Hardy 51

Guadalupe County 8

Guinn, M. H. 53

Gulf of Mexico 8

Gulick, W. M. 8

\section{$\mathbf{H}$}

Hale Center 52, 67

Harrell, Willis 69

Harrison, E. B. 52, 53, 54, 63, 64, 65,70

Harrison, L. 54

Harrison, W. B. 52, 53, 54

Harriss, Baylis E. 51, 61, 69

Harriss, R. M. 51, 61, 69

Harriss, Raymond F. 51, 61, 69

Harriss, Richard T. 51, 61, 69

Harriss, W. L. 51, 61, 69

Harvey, William 47

Haskell 1, 2, 4, 8, 10, 11, 18, 19, $20,22,24,26,28,29,31,36,37$, $43,44,46,47,48,49,50,51,52$, $53,54,55 \mathrm{n}, 56,57,58,59,60$, $61,62,63,64,65,66,67,68,69$, 70

Haskell County 1, 2, 4, 6, 7, 8, 9, $10,11,12,17,19,20,22,24,28$, $29,30,31,36,37,42,43,44,45$, $46,47,48,48 \mathrm{n}, 49,50,51,52$, 55n, 56, 57, 59, 61, 61n, 64, 66, 67,70

Hastings, Frank 6, 24, 26, 28

Hawley 24

Hawley, Edward 19

Hays, J. S. 69

Healey, M. L. 48

Herren, R. W. 65, 70

Hill, Daisy 69

Hill, Edward W. 69

Hill County 48

Hockersmith, H. D. 18

Holliday 4, 11, 18, 24, 26, 45

Holmes, James W. 7

Hooper, G. B. 48

Hubbard City 48

Hudson, M. S. 52, 67

Hughes, Ed S. 19
Hughes, William E. 48

Hunt, Courtney 53

Huskey, S. A. 61

Hutton, W. W. 7

\section{I}

Ikard, E. F. 7

Ikard, Will 7

Iowa Park 26

Irby, Joe 57

Irby, Robert F. 51, 61, 69

\section{J}

Jeter, R. T. 69

Jeter, W. J. 53

Johnson, Charles L. 57

Johnson, Elmer 4, 5

Johnson, J. G. 7

Johnson, Mode 7

Johnson, W. E. 53

Jones, J. L. 47, 49, 67

Jones, John Grant 17

Jones, Morgan 1, 2, 10, 11, 17, 18, $19,24,26,48,61$

Jones County 1, 2, 4, 6, 7, 8, 9, 10, $11,12,18,19,20,23,24,28,30$, $31,37,45,47,52,57,61,63,70$

\section{$\mathbf{K}$}

Kaufman, W. E. 19

Kansas 8, 17

Keeler, D. B. 22, 25

Kell, Frank 17

Kemp, Joseph A. 17

Kennedy, Mary Kate 52, 53, 54

Kennett (Missouri) 71

Klose, Jerry Don 69

Knapp, Seaman Asahel 2

Knox County 1, 2, 4, 6, 7, 8, 9, 10, $11,12,17,18,19,20,26,28,30$, $31,35,37,41,42,45$

Knox Prairie 8

\section{$\mathbf{L}$}

Labririe, John 47

Lake Diversion 30

Lake Kemp 30

Lewellen, J. C. 51, 69

Linville, F. A. 69,70

Linville, Nora 70

Little Wichita River 24

Long, C. D. 57

Lubbock 1, 2, 65

Lytle Creek 8
M

Mabelle 4, 20

Mankins 4, 11, 20, 45

Mart 48

Matthews, J. A. 46 (see also John A. Matthews)

Matthews, John A. 8 (see also J. A. Matthews)

Maxwell, R. W. 51, 61

McClain, J. R. 7

McConnell, H. G. 22

McDaniel, W. T. 49, 50, 57, 58, 59

McGregor, Charley 52, 55n, 63

McLennan, R. E. 53

McLennan County 48, 57

Meade, G. P. 17

Merkel 18

Mills, C. C. 7

Montgomery, R. C. 49

Morgan, W. T. 53

Motz, Charlie, Jr. 67 (see also Charles Motz Jr.)

Motz, Charles, Jr. 54 (see also Charlie Motz Jr.)

Munday 2, 4, 11, 18, 19, 20, 22, 24, $25,26,28,29,31,35,37,41,42$, $45,49,57 \mathrm{n}, 64$

$\mathbf{N}$

New York (New York) 19, 24, 51, 61,69

Nolan County 52, 63, 70

Noodle Creek 29

$\mathbf{O}$

Oklahoma City (Oklahoma) 26, 51, 61,69

Orr, J. T. 52, 67

\section{$\mathbf{P}$}

Paint Creek 46

Palo Pinto County 7

Parks, A. 11

Persons, D. H. 53, 65

Phillips, John W. 17

Pitts, W. W. 52, 67

Prideaux, R. O. 7

Pryor, A. J. 48

Pryor, W. W. 57

$\mathbf{R}$

Red River 4

Reynolds, George T. 8, 46

Rheinland 18 
Rice Springs 46, 47

Roberts, Creed 7

Roberts, Emett 7

Roberts, John 7

Robertson, R. V. 51

Robertson County 69

Rock Island County (Illinois) 11, 50,59

Rogers, J. H. 48

Rosebud 48

Round Timbers community 7

\section{$\mathbf{S}$}

St. Louis (Missouri) 8, 10

Sagerton 64, 69

Salt Fork 47

Sanders, Fred 20, 67 (see also Fred T. Sanders, F. T. Sanders)

Sanders, Fred T. 28, 31, 49, 50, 52, 59, 60 (see also Fred Sanders, F. T. Sanders)

Sanders, F. T. 48, 49, 50, 54, 55n, 57n, 59, 64 (see also Fred Sanders, Fred T. Sanders)

Sanders, Roy 54 (see also Roy A. Sanders)

Sanders, Roy A. 54 (see also Roy Sanders)

Scales, G. T. 61

Searcy, I. G. 46

Seymour 2, 4, 7, 8, 11, 17, 18, 19, $20,21,22,24,25,26,27,30,31$, $33,34,37,38,39,40,45,47,48$, $57,57 \mathrm{n}, 67,71$

Shackelford County 46

Shelley, C. W. 64

Shelley, Lola Bell 64

Sherman 57n

Sherrill, H. L. 48

Sherrill, R. E. 28, 31, 62

Simmons, J. F. 69

Simpson, John 7
Smith, L. M. 47

Smith, N. C. 47, 49, 67

Smithville 59, 63

Somerville, W. F. 17

Sonnamaker, Virgil 2

Sparks, B. E. 19

Spurlock, M. F. 63, 65

Stamford 2, 4, 6, 10, 18, 19, 20, 20n, 22, 23, 24, 25, 26, 28, 29, $30,31,37,45,48,71$

Standifer, Elbridge 47

Standifer, W. R. 8, 47

Stevens, J. W. 7

Stith, Eula T. 51

Stith, Will 31, 61

Stokes, Lynn 52, 67

Swenson, Swante M. 10

Swenson, W. G. 19

\section{$\mathbf{T}$}

Taylor County $1,2,4,6,7,8,9,10$, $11,12,19,20,28,28 \mathrm{n}, 29,30$, $31,43,45,46,51,54,61$

Taylor 48

Temple 48

Thistle 47

Throckmorton County 17, 48n

Trumbull, Frank 19

Tucker, A. J. 7

Tucker, Thomas F. 8, 46

V

Vontress 60

Vose, Alden H. 51, 61, 69

W

Waco 26, 48

Wade, H. D. 25 (see also Homer Wade, Homer D. Wade)

Wade, Homer 24, 25, 26 (see also
H. D. Wade, Homer D. Wade)

Wade, Homer D. 22, 26, 28 (see also H. D. Wade, Homer Wade)

Waggoner, Daniel 7

Waggoner, Tom 7

Wair, A. H. 53, 64, 66

Walker, G. L. 69

Waller, C. C. 48

Walters, H. 19

Watson, L. B. 52, 53, 64

Weatherford 8

Weinert, F. C. 19

Weinert 2, 4, 19, 20, 24, 28, 31, 45, $60,61,64,69$

Wells, W. F. 69

Whatley, Emmett M. 51

Whitewright 48

Whittemore, M. W. 48

Wichita County 1, 2, 4, 6, 7, 8, 9, $10,11,12,18,19,25,26,28,29$, $31,37,42,43,46$

Wichita Falls 2, 4, 6, 7, 10, 11, 17, $18,19,20,22,24,25,26,28,29$, $37,45,57 \mathrm{n}, 61$

Wichita River 4, 8, 17

Wichita Valley 17

Wilfong, R. D. 46

Williams, M. L. 52, 63, 70

Williamson, George 31

Williamson County 48

Willow Springs 8

Wills Point 52, 67

Woods, Dr. 62

Wooten, W. E. 54, 67

Wright, T. H. 49, 50, 51, 55n, 64

$\mathbf{Y}$

Yoakum, Benjamin F. 19, 25

$\mathbf{Z}$

Zahn, Paul 51 
